\begin{abstract}
UNIVERSIDADE DE SÃO PAULO
FACULDADE DE FILOSOFIA, LETRAS E CIÊNCIAS HUMANAS - DEPARTAMENTO DE FILOSOFIA

PROGRAMA DE PÓS-GRADUAÇÃO EM FILOSOFIA
\end{abstract}

VICTOR HUGO FONSECA DA SILVA COELHO

A HERANÇA E O PARRICÍDIO:

O ELEATISMO NO SOFISTA DE PLATÃo

VERSÃO CORRIGIDA

São Paulo

2019 


\section{A HERANÇA E O PARRICÍDIO: \\ O ELEATISMO NO SOFISTA DE PLATÃO}

Dissertação apresentada ao

Programa de Pós-Graduação em Filosofia do Departamento de Filosofia da Faculdade de Filosofia, Letras e Ciências Humanas da Universidade de São Paulo, para obtenção do título de Mestre em Filosofia sob a orientação do Prof. Dr. Roberto Bolzani Filho

VERSÃO CORRIGIDA

São Paulo

2019 
Autorizo a reprodução e divulgação total ou parcial deste trabalho, por qualquer meio convencional ou eletrônico, para fins de estudo e pesquisa, desde que citada a fonte.

Catalogação na Publicação Serviço de Biblioteca e Documentação

Faculdade de Filosofia, Letras e Ciências Humanas da Universidade de São Paulo

$\mathrm{C} 672 \mathrm{~h}$

Coelho, Victor Hugo Fonseca da Silva Coelho

A herança e o parricídio: o eleatismo no Sofista de Platão / Victor Hugo Fonseca da Silva Coelho Coelho ; orientador Roberto Bolzani Filho Bolzani Filho. São Paulo, 2019.

$103 \mathrm{f}$.

Dissertação (Mestrado)- Faculdade de Filosofia, Letras e Ciências Humanas da Universidade de São Paulo. Departamento de Filosofia. Área de concentração: Filosofia.

1. Platão. 2. ontologia. 3. eleatismo. 4. dialética. 5. discurso. I. Bolzani Filho, Roberto Bolzani Filho, orient. II. Título. 


\section{ENTREGA DO EXEMPLAR CORRIGIDO DA DISSERTACCÃO/TESE}

\section{Termo de Ciência e Concordância do (a) orientador (a)}

Nome do (a) aluno (a): Victor Huas Fousree de SiCva Coelha Data da defesa: $01 / 10 / 2019$
Nome do Prof. (a) orientador (a):

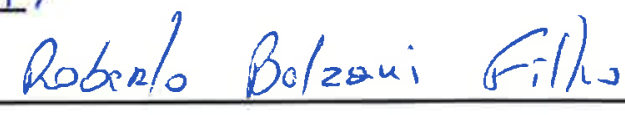

Nos termos da legislação vigente, declaro ESTAR CIENTE do conteúdo deste EXEMPLAR CORRIGIDO elaborado em atenção às sugestões dos membros da comissão Julgadora na sessão de defesa do trabalho, manifestando-me plenamente favorável ao seu encaminhamento e publicação no Portal Digital de Teses da USP.

São Paulo, $27 / 02 / 2020$

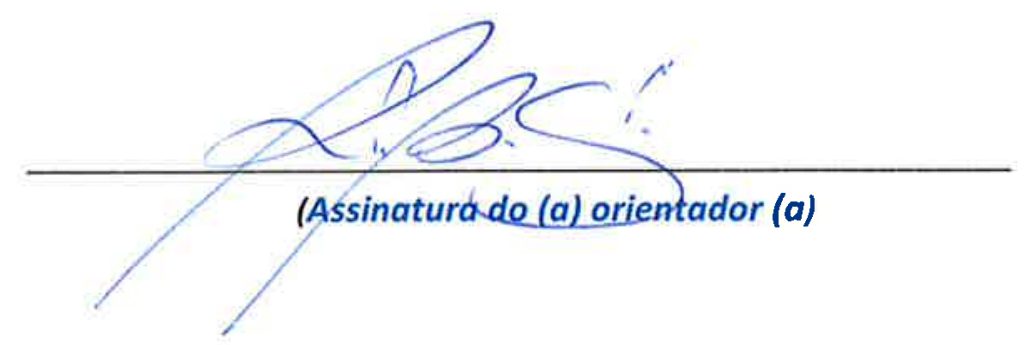


A Lucia Maria da Fonseca e José Elias Fonseca (in memoriam), sempre presentes em minha ausência 
"Qual seria o negócio da filosofia? Não se trata, necessariamente, de propagar uma visão de mundo (seja ela historicista, naturalista, socionaturalista ou espiritualista), demolindo a visão adversa, caçando os erros categoriais que lhe são subjacentes. Há uma hybris que se esconde sob a aparente modéstia da chamada metafísica descritiva: a de poder, como se nada fosse, circunscrever, sem resto, a natureza e o espírito humanos, na forma de uma teoria positiva. Pode ser que a tarefa da filosofia seja mais modesta: a de nos livrar de certas ilusões, que não deixam de nos fascinar e de nos seduzir, a principal ilusão da filosofia seria a de nos fornecer, com uma teoria, uma ancoragem no Ser, uma linguagem finalmente transparente, esse instrumento que nos garantirá, para sempre, contra o erro e tornará possível a fundação de nossa forma de vida, ignorando sua contingência absoluta." (Bento Prado Jr., Ipseitas, pp. 95-96, grifos do próprio autor) 


\section{RESUMO}

Visamos com esta dissertação compreender os movimentos lógico-ontológicos operados por Platão no diálogo Sofista. O diálogo nos parece de grande importância na obra platônica pois: (i) é por meio da ontologia ali estabelecida que Platão institui a forma proposicional de um discurso que possa ser valorado tanto como verdadeiro quanto como falso; e (ii) a relação entre lógica e ontologia parece estar indicada por certa mudança na Teoria das Formas que, de algum modo, forneceria, ainda na obra platônica, uma teoria da boa imagem e da boa mimese. Em primeiro lugar, procuramos identificar a aporia eleática apresentada no início do texto, aporia que nega a possibilidade de discursos falsos e de discursos verdadeiros não tautológicos. Em segundo lugar, buscamos compreender o modo como Platão parece contornar tal aporia por meio da formulação de um tipo de oposição propriamente dialética: a antítese entre os gêneros ou formas. Podemos dizer, portanto, que, como condição para a bipolaridade do discurso temos, no caso platônico, a conjunção ou dissociação entre as formas, isto é, a conjunção e dissociação garantidas por meio do esquema fornecido pelo célebre método da divisão (diairesis). Será esta operação realizada pelo Estrangeiro de Eleia que permitirá, ao final do diálogo, que os diferentes elementos do enunciado sejam articulados sem que o emissor esteja necessariamente enredado pela contradição discursiva. Assim, acreditamos ser possível nos aproximar do jogo de rupturas e continuidades que parece haver entre Platão e a filosofia do grande mestre de Eleia: o platonismo pretende matar seu pai para que a filosofia deste continue viva, ou seja, para impedir que a implosão sofística das teses de Parmênides faça com que o eleatismo sucumba aos interesses dos mestres da retórica e da ilusão. 


\section{ABSTRACT}

We aim with this master dissertation to understand the logic-ontological moves operated by Plato in the Sophist dialogue. This dialogue seems to us enormly important in the platonic works, because: (i) its by virtue of the ontology there estabilished, that Plato found the propositional form of discourse, that can be valuated as true such false; and (ii) the relation between logic and ontology seems be indicated by some change in the Theory of Forms, that in some manner, could give us, in platonic work, a theory of good image and good mimesis. First of all, we seek to indentify the eleatic aporia presented in the beginning of the text, aporia that deny the possibility of false discourses and of not tautological truth discouses. Secondly, we seek to understand the way that Plato seems outline this aporia by the formulation of a kind of oposition properly dialetical: the antithesis between the genres or forms. We may say, therefore, that as condition to bipolarity of discourse, we have in the platonic case, the conjunction or dissociation among the forms, i.e., the conjunction and dissociation guarantees by schema provided by famous methode of division (diairesis). Will be this operation made by Strange of Eleia, that will allows, in the end of dialogue, that the diferents elements of proposition be articulate without the issuer be necessarily involved by discoursive contradiction. Thus, we consider it is possible to approach us to the play of disruptions and permanences that seems to be between Plato and the philosophy of great master of Eleia: the platonism intent to kill his father so that his philosophy can proceed alive, i.e., to hinder that the sofistic implosion of parmenidean thesis makes the eleatism succumb to the interests of masters of retoric and illusion. 
Agradecimentos

Agradeço em primeiro lugar ao Prof. Roberto Bolzani Filho, meu orientador desde a iniciação científica, pela paciência com minhas obsessões e inseguranças, assim como pela precisão cirúrgica e certeira dos comentários.

Márcio Mauá Chaves foi a pessoa que mais me acompanhou neste projeto: esteve, de fato, do princípio ao fim. No início, como professor, encarou a tarefa hercúlea de me ensinar o pouco que sei de grego antigo. Ao longo do processo, o aluguei com inúmeras conversas que pouco a pouco iam me apresentando a cultura helênica. Seu entusiasmo infinito, por fim, me presenteou com uma amizade e uma coerência que me inspiram para a vida.

As sugestões e observações dos professores Evan Keeling e Eliane Christina de Souza foram muito preciosas, desde o exame de qualificação até a defesa da dissertação. O professor Paulo Ferreira Tadeu se juntou a eles na banca de defesa e me ofereceu sua já característica acuidade analítica, que se encontra, no entanto, imersa numa elegância acadêmica assombrosa. Devo mesmo dizer que a presença do professor Paulo Tadeu na banca coroou o forte impacto que o seu rigor intelectual, sua preocupação filológica e sua postura acadêmica irretocável operaram sobre mim deste o início de minha pesquisa.

Tive o prazer e a honra de, nos momentos finais do meu mestrado, ter participado do estimulante núcleo de filosofia antiga do centro de cultura helênica Areté. Agradeço ao centro Areté por manter este importante polo de pesquisa e também aos companheiros de grupo que me ofereceram, em nossos "Saturdays Mornings", tanto interlocução na pesquisa e quanto uma inesperada amizade. Sem Paulo Ferreira, Victor Gonçalves, Nataly Ianicelli, Dionatan Tissot, Fernando Gazoni, Breno Zuppolini, Bruno Conte, Nicola Galgano, Eduardo Wolf, Luiz Fernando de Aguiar, Ana Beatriz Barros e Tiago Tranjan minha pesquisa seria muito mais solitária e minha atividade intelectual muito menos efervescente. A convivência com o espírito livre, diletante e democrático de Vicente Sampaio fez aquelas feijoadas dos "Saturdays Afternoons" serem D'Pirá e aqueles cafezinhos realmente inspiradores.

Luiz Eduardo Freitas e Antonio Kertenetzky, companheiros de orientação e de jornada, foram muito solícitos ao ler minha versão para a qualificação e fazer comentários inteligentes. Ivan "Jimmy" de Oliveira também leu algumas partes deste trabalho e aparece já há tempos como um interlocutor filosófico importante para mim. 
Pedro Galé e Edson Querubini sempre estiveram dispostos a ouvir minhas desilusões acadêmicas e, com sua erudição, deram vazão aos meus interesses tão diversos. A amizade de Fábio Franco certamente marcou minha formação intelectual desde o segundo ano de faculdade: sou-lhe grato por isso. Daniel Nagase sempre me surpreendeu com indicações específicas e certeiras demais para um "não-especialista" em filosofia antiga.

A inteligência e o entusiasmo intelectual do prof. Márcio Suzuki por algumas vezes me tiraram do pantanoso terreno da dissertação e trouxeram ar puro para os meus pulmões. Após ter realizado um curso de política antiga com o Prof. Sergio Cardoso, posso dizer mesmo que me tornei seu fã. Agradeço muito a generosidade amistosa e descontraída do prof. Sérgio.

Ao longo da dissertação frequentei o curso de história de arte do prof. Rodrigo Naves, experiência muito importante para mim. Por sorte, ainda continuo por lá. Com o Rodrigo tenho aprendido muito, e não apenas no olhar artístico: a generosidade do Rodrigo é sempre simpática aos interesses dos outros, sua ética e seu caráter não ficam nada atrás daquele que ele vê nas esculturas de Amílcar de Castro.

Agradeço ao Grupo Teatral Hangar de Elefantes e ao Teatro Oficina, que me deram régua e compasso para lidar com o mundo. Penso que minha ligação com o antropólogo Pedro Felizes, com o iluminador Renato Banti e com o ator/diretor Caio D'Aguilar ainda faz permanecer aceso em mim alguma fagulha do fogo de Sêmele. Felipe Santos (desta vez não te esqueci) e Fernando Dalton, velhos amigos da mais alta estima, deram o tom de minha formação: nesta correnteza caudalosa da vida, que no nosso caso corre do mar para o interior, não consigo deixar de nos ver como uma cachoeira de três quedas.

Sem a moradia no CRUSP não teria conseguido realizar qualquer projeto acadêmico. Aproveito, portanto, a ocasião de marcar a importância dos programas de permanência estudantil não só para os estudantes beneficiados, mas para a universidade como um todo. O Conjunto Residencial também me forneceu uma importante interdisciplinaridade formativa e amigos muito queridos: agradeço a todos os amigos do CRUSP. Agradeço também aos funcionários da secretaria do Departamento de Filosofia da USP, que sempre mostraram tão solícitos e dedicados. Direciono um agradecimento especial à Mariê Pedroso, que nos atura a muitos anos com alegria e descontração. 
Agradeço também aos amigos mais próximos, que tornaram a jornada menos solitária e penosa. Há um bom tempo tenho o prazer de contar com a distinta companhia da querida Maria Aguilera, Maria Sette, João Pace, Juliana Giannini, Moa e Guilherme Marchesan: companheiros de toda hora e todo papo.

Desde o início da faculdade, tive a sorte e a felicidade de contar com um grupo de amigos que acabou mesmo por se tornar uma verdadeira família. Não saberia como agradecer por todos estes anos não só de amizade e de companheirismo, mas de formação intelectual ativa e conjunta (talvez um tipo de "synfilosofia"?). Por todos eles tenho um carinho que pode ser notado com facilidade, mas que não é possível ser medido. Assim, agradeço a Pedro José y Diego pela amizade incondicional e eterna, bem como pelos inigualáveis ovos fritos de gema mole, símbolo do acolhimento e do afeto que nos une. Sua mãe, a prof. Thelma Valentina, como já foi dito por outro membro do grupo, ao deixar sua casa literalmente aberta a todos, depositou mesmo mais confiança em nós do que merecíamos: agradeço a ela pelo alimento físico e mental de todo aquele tempo em que passamos em sua casa. Matheus Ichimaru é o tipo de amigo com quem sempre se pode contar, mas não exatamente para comparecer nas bancas de defesa de mestrado. Seu carisma forma em torno dele uma força centrípeta, logo em direção a ele, que é o maior especialista do Brasil no ruído anômalo do calorímetro hadrônico do CMS do LHS (um baita posto para um físico). Seu perene descontentamento com as monotonias da vida nos fez ganhar um bom quadro para a filosofia política. André "Jorge" Carvalho, meu tradutor oficial para o inglês, nos brindou todos estes anos com seu humor ácido e veloz. Por detrás daquele Jorge que não se leva a sério, piadista à la Cruz Costa, temos o brilhantismo e agudeza intelectual de André Carvalho. Pedro Ivan de Sampaio se vê como o esteio moral de todos nós: é claro que ele está tentando enganar a si mesmo. Me sinto muito feliz de pertencer ao seu pequeno círculo de amigos: somente estes privilegiados saberão a absoluta generosidade e lealdade de que ele é capaz. Nossa germanófila, Juliana Martone, foi sempre minha companheira de angústias e reclamações, o que não excluiu uma troca acadêmica vigorosa e gentil com esta que é uma das pessoas mais dedicadas que conheço. Rafael Zambonelli esconde, por detrás de sua timidez, uma cornucópia de interesses: sua paixão pelo palmeiras, pelo violão clássico ou pelos sintetizadores não deixam eclipsar a carreira de um fenomenólogo promissor. Mateus Toledo é tão brilhante quanto desatento. Mateus é polymatha e diletante e, como na história de Tales de Mileto, vive realmente no mundo das abstrações, mas ainda creio que a culpa dos tropeços não é dele, mas sim dos 
buracos que que a vida prática coloca em nossos caminhos. Há uma leveza ímpar na presença de Natália Carneiro. Junto a seu carisma, é ela quem frequentemente nos traz a urgência de alguns dos incontornáveis debates de nossos tempos. Sempre pude contar com a animação intelectual de Pedro Nagem, em nossas conversas sinto mesmo que realizamos quase que uma competição de obsessões. Michel Amary foi um daqueles que me recebeu na filosofia, lembro-me dele no meu dia de matrícula: sua atuação de político em campanha obnubila uma certa doçura em seu trato com o mundo. O incomparável Wilson Krugner, esta enciclopédia viva da política brasileira, se juntou recentemente a nós: nunca vi uma entrada em cena mais triunfal.

Agradeço a Leandro Paixão pela rara e estimulante amizade que construímos. Espero, de fato, que um dia eu consiga ler os versos da vida com toda a intensidade que ele lhes confere.

Não saberia dizer quantas vezes, após uma madrugada inteira de estudo e escrita, recebi das mãos de Adriana Evangelista um café matinal e sonolento. Agradeço a ela e a Andrigo Souza por toda a paciência, bem como por me proporcionarem um oásis de tranquilidade e calma muito propício ao trabalho intelectual.

Como não poderia ser diferente, entrego a última palavra desses agradecimentos àquela que por todos esses anos esteve ao meu lado. Nela encontrei a companheira perfeita para as aventuras e desventuras da existência. Incapaz de falar alto, sua voz baixa carrega a justa medida entre o que deve ser dito e não dito. Sua perspicácia e inteligência são, por outro lado, como linha e agulha para tecer e aprumar minhas novas e velhas roupagens. Elegante na vestimenta e no trato, Bruna Carolina Evangelista parece mesmo ter sido feita sob medida para tudo aquilo que sou e pretendo ser.

Mais do que nunca devemos agradecer ao CNPq, que subsidiou parte deste projeto. Tal financiamento foi condição para a realização deste trabalho acadêmico. 
SUMÁRIO

NOTA SOBRE AS EDIÇÕES UTILIZADAS

INTRODUÇÃO

15

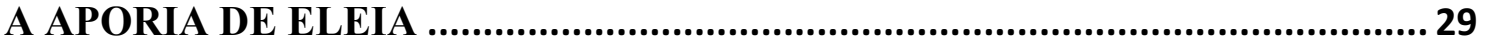

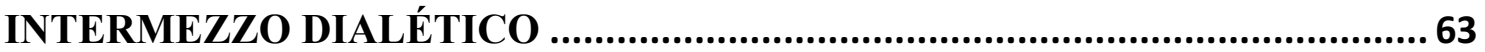

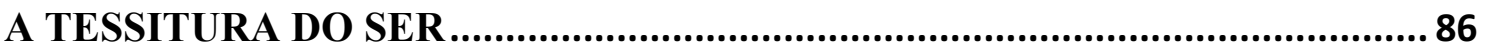

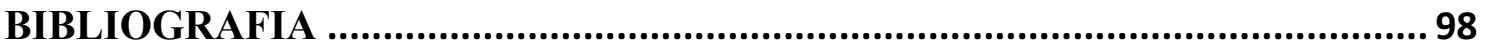




\section{NOTA SOBRE AS EDIÇÕES UTILIZADAS}

Utilizamos, em associação, duas edições do texto grego do Sofista: a de D. B. Robinson (OCT), publicada pela Oxford University Press; e a de A. Diès, publicada pela Editora Les Belles Lettres. Por vezes consultamos também a edição de J. Burnet (coleção antiga da OCT). Se a edição de Robinson teve mais acesso à colação direta dos manuscritos, de um papiro publicado em meados do século XX, e de edições as mais variadas do texto, por outro lado, a edição de Diès, confere maior importância aos testemunhos indiretos (sobretudo Estobeu e Simplício), fato facilmente identificável no aparato crítico exposto ao longo da edição da Belles Lettres. Auguste Diès considera válido utilizar o manuscrito Y (Vindobonensis 21, provavelmente da mesma família que o manuscrito $\mathrm{T}$ - chamada por Robinson de Família II), devido justamente à proximidade deste manuscrito com a tradição indireta antiga. D. B. Robinson, por sua vez, seguindo Apelt e Burnet, recusa a utilização de Y provavelmente pela sua grande quantidade de erros. Ademais, Robinson inova ao acrescentar D (Venetus gr. 185), da mesma família de B (manuscrito base), entre os manuscritos consultados para o estabelecimento de sua edição. Ao utilizar as duas edições em conjunto, esperamos tomar uma postura comedida frente às diferenças editoriais destes dois grandes estudiosos do texto platônico.

Salvo indicação contrária, as citações em português foram feitas a partir da tradução de Henrique Murachco, Juvino Maia Jr. e José Trindade Santos publicada pela editora portuguesa Fundação Calouste Gulbenkian e, como reza a convenção, sempre com referência à paginação da edição de Henricus Stephanus. Quando nos referimos, em nossas citações, ao número das linhas do texto platônico, sempre tomamos como referência as edições mais recentes da Oxford Classical Texts (OCT). Consultamos também a tradução e as notas feitas por Néstor-Luis Cordero para a edição da GFFlammarion e a tradução de Diès, na já citada edição da Belles Lettres.

Para o Poema de Parmênides, o texto grego utilizado foi aquele estabelecido em Deux chemins de Parmenide, de Néstor-Luis Cordero em comparação com aquele instaurado em Die Fragmente der Vorsokratiker, por Hermann Diels e Walther Kranz. Salvo indicação contrária, utilizamos a tradução de José Cavalcante de Souza (publicada pela coleção "Os Pensadores" da Abril). Informaremos sempre que realizarmos alguma 
modificação na tradução do Prof. Cavalcante de Souza. Utilizamos para as citações dos versos do Poema a numeração proposta por Diels-Kranz aos fragmentos de Parmênides.

Para Antístenes, nos utilizamos do livro de Susan Prince: Antisthenes of Athens: texts, translations, and commentary, publicado em 2015. Buscamos sempre informar não somente a numeração de Prince aos fragmentos e testemunhos de Antístenes, mas também aquela mais antiga de Decleva Caizzi. As traduções utilizadas variam conforme a obra que contém os testemunhos de Antístenes, as fontes foram citadas ao longo do texto. Quando não houve tradução para o português, fizemos a tradução diretamente do grego.

Para Górgias, utilizamos o texto de I Sofisti, de Mario Untersteiner, e Si Parmenide, de Barbara Cassin. A numeração foi baseada na edição já citada de DielsKranz.

Para as demais obras, as edições e traduções serão sempre citadas ao longo do trabalho. Todas as edições utilizadas encontram-se referenciadas na bibliografia. 


\section{INTRODUÇÃO}

Qualquer pesquisa que trate da Antiguidade exige sempre, de partida, uma posição do pesquisador em relação a um problema fundamental: devido aos milênios de tradição crítica escrita, é natural que ao seu objeto de estudo se some uma biblioteca de comentários das mais variadas épocas e gostos. Este fato, num primeiro momento, nos leva inevitavelmente à sensação de nossa falta de originalidade no que diz respeito às análises dos documentos históricos tratados. Podemos dizer ainda que, em relação a tais textos, que foram trabalhados por exegetas certamente muito mais cuidadosos que nós, sempre parecemos estar em uma impagável e adiada dívida. Mas, afinal, por que, após mais de dois mil anos de belos comentários, deveríamos em pleno século XXI, renitentemente, fazer mais uma leitura de um texto antigo, leitura que, no melhor dos casos, se mostraria pouco original? De fato, originalidade é algo que não podemos pretender.

Por outro lado, podemos dizer que a leitura de tais textos traz uma ótima particularidade: devido ao seu caráter clássico e permanente, temos, com o estudo desses documentos, uma oportunidade ímpar para observar as variações e mudanças nas posturas interpretativas que a história dos comentários nos proporcionou, investigação que não raro denuncia as preocupações estritamente filosóficas por detrás daquela exegese aparentemente isenta de alguém que se apresenta como um mero explicador de texto. Esta indistinção, por vezes notada, entre a explicação do texto e as posições filosóficas tomadas pelo seu interprete possibilitou, inclusive, que, uma vez, um eminente filósofo dissesse que a própria história da filosofia é a história das notas de rodapé a certo autor antigo, ou seja, a filosofia consistiria num retorno incessante e quase mítico a um mesmo repositório textual determinado que lhe serviria de origem ${ }^{1}$. De qualquer modo, certo é que há tempos colocamos e recolocamos a questão que diz respeito à relação entre a

\footnotetext{
1 “The safest general characterization of the European philosophical tradition is that it consists of a series of footnotes to Plato. I do not mean the systematic scheme of thought which scholars have doubtfully extracted from his writings. I alude to the wealth of general ideas scattered through them. His personal endowments, his wide opportunities for experience at a great period of civilization, his inheritance of an intelectual tradition not yet stiffened by excessive systematization, have made his writings an inexhaustive mine of suggestion. Thus in one sense by stating my belief that the train of thought is Platonic, I am doing no more than expressing the hope that it falls within the European tradition" (WHITEHEAD, 1978, p. 39)
} 
filosofia e sua história: com pouca originalidade, mais uma vez não poderemos deixar de colocá-la.

Comecemos fazendo uma distinção interessada e didática: no que diz respeito à abordagem que podemos fazer da história da filosofia, pelo menos duas diferentes posições podem ser assumidas (mesmo que, como veremos adiante, no limite, elas não sejam tão distantes assim uma da outra $)^{2}$. Na primeira delas podemos dizer que as diferentes análises de alguns textos clássicos, incluindo aí também casos que poderiam ser classificados como "erros de interpretação", abrem caminho para diferentes posturas filosóficas. Podemos ver no caso relatado por Pierre Hadot acerca de uma leitura possivelmente porfiriana do Parmênides de Platão um caso paradigmático deste procedimento que parece ter projetado por boa parte da história da filosofia uma suposta distinção entre o ser (infinitivo) e o ente (particípio), distinção esta a qual podemos registrar a data e hora de nascimento (HADOT, 1968, Tomo I, p. 129-132; HADOT, 1973; HADOT, 2010 [1968], p. 9). Seria da tentativa de solução dos contrassensos ou disparates presentes numa doutrina escrita que apareceriam os novos conceitos e as distinções filosóficas que atenuariam tais problemáticas textuais ${ }^{3}$. Deste ponto de vista, não estaríamos procurando a verdade última implícita na sistematicidade garantida pela autoridade daquele texto, isto é, não precisaríamos realizar a tarefa hercúlea de identificar a estrutura do texto antigo com nossas pretensões modernas de razão sistemática. Diferentemente, seria preciso passar em revista a história dos comentadores de um determinado texto para identificar o nascimento das novas questões que tal exegese ensejou, ou seja, as torções conceituais que a todo tempo permitem a aparição de problemáticas filosóficas inesperadas e, até então, inexistentes. A história da filosofia seria, portanto, uma incansável busca de atenuação de incoerências textuais específicas, mas que partiriam sempre do texto com uma pretensão de estabelecer uma solução que tenha coerência lógico-sistemática para cada doutrina em questão. Digamos que essa abordagem privilegiaria a historicidade e particularidade do texto.

\footnotetext{
${ }^{2}$ É claro que diversas outras posturas legítimas e interessantes também podem ser assumidas. Nossa escolha pelo tratamento dessas abordagens quanto à história da filosofia não é desinteressada, mas pretende nos direcionar sem rodeios para uma certa discussão em torno de nosso tema, bem como de encaminhar para nossas próprias posições.

3 "Mais il doit constater un fait: ce sont les contrasens et les incompréhensions qui, très solvente, ont provoqué une évolution importante dans l'histoire de la philosophie, et qui, notamment, ont fait apparaître des notions nouvelles." (HADOT, 2010 [1968], p. 9)
} 
De maneira semelhante, mas inversa, pois partiria da teoria filosófica em direção à análise do material particular, é possível, por outro lado, que tomemos uma outra postura: aquela de projetar nossas próprias posições filosóficas, ou ao menos aquelas hegemônicas de nosso meio ou época, sobre a nossa análise das obras canônicas. Desta maneira, reconheceríamos sempre as mesmas "questões essenciais da filosofia" por detrás das diversas roupagens proporcionadas por cada época ou filósofo. Em casos mais extremos, alguns partidários deste ponto de vista, num rompante de dissociação entre a filosofia e sua história, podem mesmo chegar a considerar a história da filosofia irrelevante para o exercício propriamente filosófico. Digamos que isso pode acontecer porque essa abordagem privilegiaria a sistematicidade da razão universal (e não a razão interna de cada doutrina) em detrimento da história documental. Logo, podemos dizer que, nos casos mais moderados, para os partidários desta posição, os problemas filosóficos encontrados nos textos antigos podem ser entendidos como prefiguração daqueles paradoxos enfrentados pela nossa razão em desenvolvimento ${ }^{4}$.

O mais interessante seria notar que, talvez, a partir da junção destas duas abordagens, pudéssemos passar a identificar a existência de diversas linhagens filosóficas ou conceituais, ou seja: ao mesmo tempo que, num processo de tradução, aproximamos aquele texto antigo dos nossos termos, por outro lado, devemos respeitar as particularidades do texto que nem sempre se apresentam a nós de uma maneira evidente. Assim, poderíamos, talvez, tomar consciência de que cada sistema filosófico contém em si uma interpretação de diversos sistemas filosóficos anteriores que lhe são, por sua vez, partes constituintes. Isto é, tais interpretações e comentários aos textos são mesmo constituintes de qualquer pretensão de sistematicidade filosófica.

Evidentemente, essas disputas propriamente filosóficas inseridas na interpretação de textos não devem abrir mão do auxílio dos rigorosos instrumentos técnicos disponíveis (quanto a isso, parece que, de fato, a tendência é justamente a oposta: as análises estão

\footnotetext{
${ }^{4}$ Talvez uma boa descrição desta posição possa ser vista no comentário de Jonathan Barnes à recepção dos textos aristotélicos em Oxford: "Sans dédaigner la philologie, l'analyse ne s'engage avec elle que dans la mesure où elle peut contribuer à la compréhension philosophique; et on se sert de la logique formelle et des autres outils de la philosophie moderne plutôt que de la critique textuelle. En effet, l'orientation est toujours philosophique: on n'étudie Aristote, on ne s'adresse à ses arguments et à ses constatations, que pour en recueillir des aperçus philosophiques; lire Aristote, c'est philosopher avec lui; et tout en le lisant on essaie, encouragé par cet Hercule philosophique, de poursuivre ses propres travaux intellectuels. La tâche, c'est l'analyse détaillée du texte; la méthode revient à une approche rigoureuse, même pédante, et moderne, même anachronique; le but, c'est l'éclaircissement philosophique." (BARNES, 1977, 205-6)
} 
cada vez mais distantes de serem tecnicamente moderadas). Isto é, nos melhores casos, para que sejam justificadas, tais disputas hermenêuticas sempre se mostram diretamente ancoradas na materialidade documental da letra escrita - ainda mais que isso, o arsenal técnico será mesmo utilizado para desatar os nós conceituais nos quais estão contidos uma série de particularidades históricas que, por vezes, nos são de difícil compreensão. E vale notar que, muitas vezes, nossas dificuldades de compreensão do texto não denunciam necessariamente uma falta de sistematicidade de sua parte, mas sim evidenciam o quão distante dele já estamos.

É com os olhos nesta questão que pretendemos restringir o escopo deste trabalho sobre Platão voltando os olhos para certa discussão do século XX que diz respeito à relação entre discurso e realidade ou, o que dá no mesmo, entre lógica e ontologia. Com tal intuito, escolhemos prioritariamente estabelecer, neste trabalho, um diálogo com certa leitura dos textos platônicos centralizada nos magistrais comentários de Gilbert Ryle. De fato, Ryle atuou como um importante motor para o estudo do platonismo em Oxford. Deste modo, priorizando tal discussão, levaremos em conta também outros trabalhos associados à sua leitura ou no mesmo campo de interesse lógico e ontológico. Obviamente não trataremos as análises de Ryle em sua plenitude, não a comentaremos linha a linha, nem as citaremos incessantemente em nosso texto, muito menos comentaremos a parte estritamente filosófica de seus escritos. Nos limitaremos a tomá-las como referência para discussão da obra platônica, valorizando o que diz respeito às considerações que importam a uma certa leitura do diálogo Sofista que ganhou força no século passado e ainda parece colher seus frutos no presente.

É importante notar que, em artigo que escreve na ocasião da morte de seu supervisor de tese, G. E. L. Owen faz questão de enfatizar a revolução que, em 1939, o texto de Gilbert Ryle intitulado Plato's Parmenides iniciou no âmbito da interpretação dos diálogos tardios de Platão (OWEN, 1976-77, p. 266). O texto de Ryle com certeza cumpre uma função seminal e abre caminho para boa parte dos estudos mais consistentes e interessantes do século XX não somente no que diz respeito ao diálogo Parmênides, mas especialmente para as pesquisas relacionadas aos diálogos Teeteto e Sofista.

No entanto, a fértil interpretação de Ryle não pode ser lida apenas como fruto de uma exegese desinteressada do texto platônico. Plato's Parmenides segue o projeto de um texto publicado por ele mesmo alguns meses antes: Categories (1938). A investigação dos tipos categoriais do texto de 1938 leva Ryle a encontrar no Parmênides de Platão a 
prefiguração do chamado paradoxo de Russell e de sua consequente solução que ficou conhecida como teoria dos tipos, ambas expressas no livro escrito a quatro mãos por Bertrand Russell e Alfred North Whitehead, Principia Mathematica (1910).

Ao "paradoxo de Russell" era comparado o "argumento do terceiro homem"5 (Parmênides, 132a1-b2) para, em seguida, oferecer como resposta uma "teoria dos tipos" identificada a partir de uma leitura categorial dos gêneros supremos ${ }^{6}$ do Sofista (RYLE, 2009 [1939], p. 19, 22, 33-34, 37; RYLE, 2009 [1960], p. 70-71). Essa leitura de Ryle, para a qual uma teoria categorial seria a resposta a uma problemática ligada à teoria platônica das formas, corroboraria a interpretação bastante difundida de que Russell e o Tractatus de Wittgenstein aristotelizaram a teoria platonizante de Frege. De fato, não podemos negar que Ryle bem notou que havia uma importante analogia entre estes dois argumentos (o antigo e o moderno) e suas respectivas soluções. Certo é também que ali no Sofista aparecia pela primeira vez algo muito parecido com o que seria posteriormente chamado por Russell e Wittgenstein de "forma lógica". Em suma, para Ryle, os textos tardios de Platão se direcionavam imediatamente ao Tractatus Logico-Philosophicus de Wittgenstein (1921).

É claro que, fazendo uso dessas comparações, Ryle não pretendia insinuar qualquer "falta de originalidade" por parte de Russell, Whitehead e Wittgenstein, mas sim incluir aquela recente linha de pesquisa realizada na Grã-Bretanha como parte constituinte de um importante ramo da cultura ocidental que teria se iniciado no pensamento filosófico da Atenas clássica. No entanto, muito além disso, o trabalho de Ryle propõe certa passagem entre a atividade filosófica ela mesma e a história da filosofia ${ }^{7}$. Tal posição permitiu que muitos trabalhos específicos sobre história da

\footnotetext{
${ }^{5}$ No "argumento do terceiro homem" temos: se tomarmos que para um "F" temos sempre uma "F-dade", somos obrigados a assumir que haverá sempre e indefinidamente uma "F-dade-dade" composta de "F" adicionado à "F-dade", impossibilitando que cheguemos assim a uma forma ou ideia determinada e estável. Já no chamado "paradoxo de Russell" encontramos que "a existência de um conjunto $\mathrm{C}$ que contenha todos os conjuntos que não tem a si mesmo como elementos implica necessariamente uma contradição". Vale notar que o "paradoxo de Russell" foi encontrado por Russell na teoria que estava sendo construída por Frege, esta permitia a existência de um tal conjunto $\mathrm{C}$.

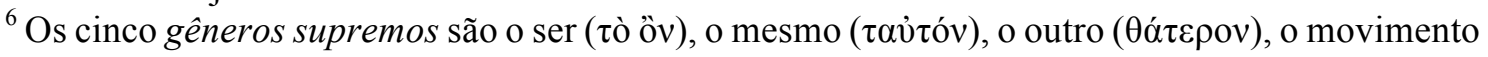

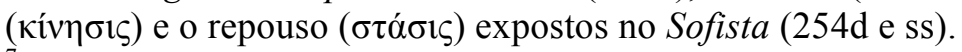

7 "Wittgenstein himself not only properly distinguished philosophical from exegetic problems but also, less properly, gave the impressions, first, that he himself was proud not to have studied other philosophers which he had done, though not much and second, that he thought that people who did study them were academic and therefore unauthentic philosophers, which was often but not always true. This contempt for thoughts other than Wittgenstein's seemed to me pedagogically
} 
filosofia antiga do período posterior ao trabalho de Ryle não só tivessem importante relevância para o debate propriamente filosófico em curso, como também fossem guiados diretamente por ele.

Entretanto, por detrás de tal ponto de vista ryleano é possível notar que está embutida certa compreensão da história da filosofia (ou mesmo uma teoria da história) que identifica sempre a reposição sucessiva dos mesmos problemas filosóficos ao longo do tempo histórico, problemas estes que, todavia, retornariam sempre sob novas roupagens. Ou seja, poderíamos dizer que esta posição de Ryle estaria identificada com uma certa concepção própria de philosophia perennis. Por outro lado, ao mesmo tempo podemos ver algo como uma constante evolução técnica das ferramentas que dispomos para compreender tais problemas filosóficos, tornando assim esses problemas cada vez mais compreensíveis e claros para uma possível solução ou uma simples dissolução desses paradoxos que chegaram até nós. Em outras palavras, talvez seja possível dizer que, por meio do uso do aparato técnico lógico-linguístico, ocorreria um preenchimento histórico daquelas questões filosóficas que já haviam sido prefiguradas historicamente nos textos antigos. Deste ponto de vista, a questão, melhor compreendida pela evolução técnica, voltaria para a análise do texto antigo fornecendo-lhe a mais correta chave de leitura para sua interpretação filosófica ${ }^{8}$.

Para sermos justos, vale notar que Ryle assume uma posição intermediária que pretende fugir da dicotomia entre a contingência histórica e a necessidade sistemática

disastrous for the students and unhealthy for Wittgenstein himself. It made me resolve, not indeed to be a philosophical polyglot, but to avoid being amonoglot; and most of all to avoid being one monoglot's echo, even though he was a genius and a friend. This resolve was all the easier to keep because, for local curricular reasons, I and my colleagues had as students had to study, and had now as teachers to teach in considerable detail some of the thoughts of, inter alios, Plato, Aristotle, Descartes, Hume, and Kant. Some of these thoughts were potent enough to make comparison of their author with, say, Wittgenstein, honorific to both, and, what matters much more, elucidatory of both." (RYLE, 1970, p. 11-12)

8 "Je ne pense pas, de surcroît, que la présupposition inverse de déclin: si celle-ci suscite des admirations parfois naïves pour les 'commencements', celle-là conduit à traiter les Grecs avec une condescendance que risque de méconnaître le génie propre de leurs solutions, voire même leur littéralité. Quel historien analytique de la philosophie n'est, au fond de lui-même, persuadé que le problème de l'être a été résolu, ou a commencé d'être résolu, le jour et le jour seulement où Bertrand Russell a distingué entre les trois fonctions du verbe 'être': existentielle, identificatrice et copulative? Dès lors, les discussions sur la partie centrale du Sophiste de Platon ont été focalisées - des milliers de pages ont été écrites là-dessus - sur la question de savoir si Platon a découvert ou non la fonction copulative de l'être. Mais cette question, liée à une lecture rétrospective et, comme je l'ai dit, condescendant, est-elle la bonne question, celle qui permet de donner au texte le maximum de sens ou, en tout cas, est-elle la seule question et ne masque-t-elle pas d'autres problématiques possibles?" (AUBENQUE, 1992, p. 25) 
filosófica: nem a história erudita dos filólogos, nem a sistematicidade a-histórica de Wittgenstein (para quem parecia haver uma ruptura completa entre a história da filosofia e o exercício do filosofar). No entanto, tal proposta de meio-termo nos direciona a uma leitura teleológica ou evolutiva da história, na qual se enxerga uma necessidade histórica que leva o conteúdo de tais textos antigos a se amalgamar imediatamente aos questionamentos filosóficos contemporâneos. Pretendemos mostrar, no entanto, que, para realizar tal empreendimento interpretativo, Ryle terá de fazer vista grossa a alguns dos elementos mais fundamentais do texto platônico?

No que concerne ao Sofista, objeto de estudo do presente trabalho, essa concepção da história da filosofia é bem marcada na interpretação do diálogo. Não é difícil ver a displicência, senão o desprezo, de Gilbert Ryle dirigido tanto ao debate filosófico que o texto platônico pretende estabelecer com relação ao eleatismo, quanto ao método dialético da divisão ${ }^{10}$ que estrutura as páginas deste texto escrito no século IV antes de Cristo. Ao

\footnotetext{
9 "En effet, plus on pousse la comparaison avec les projets contemporains de 'grammaire philosophique', plus on coupe le projet platonicien de ses racines ontologiques mais aussi du paysage grec de la langue. Dès lors, en neutralisant l'engagement ontologique qui motive la syntaxe du discours au niveau profond des relations, l'interprète n'a plus rien à mettre sous le terme de 'naturel' quand il cherche à comprendre, autrement qu'en référence à la simple convention linguistique, le rapport entre 'grammaire apparent' et 'forme logique'des expressions. Telle est semble-t-il l'impasse qui guette l'espèce de projection analytique pratiquée ici par G. Ryle, et qui me parait résulter d'un transfert, illégitime dans le contexte grec, des considérations 'onto-sémantiques', du plan de l'ontologie à celui d'un 'méta-langage' qui le surplomberait, et dont relèveraient exclusivement les concepts de relations entre concepts, à savoir justement les 'genres suprêmes' du Sophiste. C'est mon objection principale à l'encontre d'une certaine modernisation de ce dialogue. La philosophie 'analytique' qui se penche sur des questions d'histoire, se doit de déterminer les limites au-delà desquelles ses propres squèmes cessent d'être opérants pour la compréhension du problème d'origine qu'on s'est proposé d'élucider à l'aide de ces mêmes squèmes. Elle doit rester critique, et c'est cet aspect critique qui définit les limites de son application formelle.

L'application non critique d'une méthodologie analytique en histoire de la philosophie, peut aboutir à une vision déformée du texte-source." (SOULEZ, 1991, p. 28-29)

${ }^{10}$ Quanto à recusa com relação à discussão eleática ver Plato's Progress e Plato's Parmenides (RYLE, 1966, p. 28; RYLE, 2009 [1939], pp. 19-20). Quanto à divisão dialética, basta citar a seguinte passagem: "Whether Plato did or did not believe that the Method of Division was a powerful philosophic instrument, we can be quite clear that it is not so. No philosopher, including Plato, has ever tried to employ it for the resolution of any serious philosophical problem, and if they had done so they would not have succeeded. For first of all it can only be applied to concepts of genus-species or determinable-determinate sort, and it is not concepts of this sort that in general, if ever, engender philosophical problems." (RYLE, 2009 [1939], p. 43). Ver também o artigo de Ackrill sobre Ryle e o método da divisão (ACKRILL, 1970), assim como a sessão "The philosophical value of dialectic", o capítulo de Plato's Progress dedicado à dialética (RYLE, 1966, pp. 136-137)
} 
oferecermos a estes elementos a atenção que merecem, uma leitura diferente da posição filosófica do velho Platão pode aparecer frente aos nossos olhos.

O que acontece é que, ao fazer a junção entre a história circular dos problemas filosóficos que não se cansam de repor e a linearidade evolutiva das técnicas de análise do discurso, a história da filosofia operada por Ryle pode ter como resultado um anacronismo que não dê lugar ao dado específico de um texto tão distanciado historicamente e geograficamente de nossa compreensão como os textos de Platão. Tal anacronismo de Ryle já começa pela leitura categorial dos gêneros supremos do Sofista: mais do que mostrar a coleção dos vários tipos de predicados da linguagem, subconjuntos de uma proposição, Platão parece, com o diálogo, dizer, argumentando dialeticamente, quais são os pressupostos ontológicos da forma lógica de uma expressão predicativa. Não é necessário aceitar todas as reviravoltas históricas perpetradas por Ryle na ordem dos textos platônicos e aristotélicos ${ }^{11}$ para que leiamos o Sofista a partir das Categorias de Aristóteles. Talvez, se fossemos obrigados em assumir Aristóteles como medida do texto platônico, poderia ser mais interessante, em oposição a Gilbert Ryle, retomar a tese de G. E. L. Owen ${ }^{12}$ e ver nos gêneros supremos algo mais parecido com a "significação focal" (focal meaning) de Metafísica $\Gamma$, o que estaria em consonância com um indicativo da possibilidade de uma ciência geral do ser, do que com as compartimentalizações departamentais da teoria categorial do jovem Aristóteles.

Conferindo certa autonomia ao diálogo Sofista, escolhemos, portanto, não tratar do "argumento do terceiro homem" que, como já dissemos acima, foi exposto no diálogo Parmênides. Mesmo que acreditemos ser possível associar das mais variadas formas tal argumento ao diálogo Sofista, escolhemos nos deter à aporia tal como aparece textualmente no início do diálogo, isto é: o problema da existência do não ser. Tal problema pode ser dito do seguinte modo: na opção afirmativa de existência do não ser, nos direcionaríamos para uma contradição implicada por algo que, ao mesmo tempo, é e não é; e, na negativa de sua existência, a impossibilidade de veicular discursos falsos ou

\footnotetext{
${ }^{11}$ Ver principalmente Plato's Progress, Cap. 1 (RYLE, 1966, pp. 1-20).

${ }^{12}$ Logic and Metaphysics in some Earlier Works of Aristotle (OWEN, 1986 [1957], pp. 180-199) e The Platonism of Aristotle (OWEN, 1986 [1966], pp. 200-220). Devemos dizer que, para Owen, a teoria do "sentido focal" aristotélica escaparia do argumento do terceiro homem. Para uma visão divergente da de Ryle, ver Self-Predication in the Sophist (HEINAMAN, 1981). Neste artigo o autor defende que a ontologia do Sofista não escaparia do paradoxo da teoria das formas indicado pelo argumento do terceiro homem.
} 
imagens desprovidas de um modelo, pois seria impossível dizer ou ter contato com algo que não é. Neste sentido, ao resolver a aporia do não ser, o intuito de Platão no diálogo Sofista seria garantir as condições ontológicas para a existência de imagens corretas e imagens deturpadas, de discursos verdadeiros e falsos (ou seja, o princípio de bivalência proposicional), em suma, o objetivo seria possibilitar uma boa e uma má mimese ${ }^{13}$.

Portanto, podemos dizer que as questões acima dirigiram o presente trabalho a se estruturar do seguinte modo: esse imbróglio, que chamamos de "aporia do não ser", ao lado da consequente "aporia do ser", será tratado no primeiro capítulo desta dissertação, destinada a colocar os termos do problema ontológico tratado no diálogo. É inevitável que, para o tratamento do problema, façamos referência à tradição filosófica do eleatismo, berço da concepção helênica acerca do ser e da existência: a aporia do não ser é uma aporia essencialmente eleática, muito provavelmente identificada no seio do próprio Poema de Parmênides. Podemos depreender das fontes antigas (o que nos restou de Górgias ou Antístenes) o fato de ser bem possível a existência de uma disputa, na Atenas do século IV, em torno da interpretação do Poema de Parmênides. Ao que parece, tal disputa interpretativa seria decisiva para a posteridade filosófica.

Dado que a concepção grega de verdade estava atrelada ao ser, mostraremos, então, neste capítulo, que a divisão aparentemente trivial da arte da produção de imagens

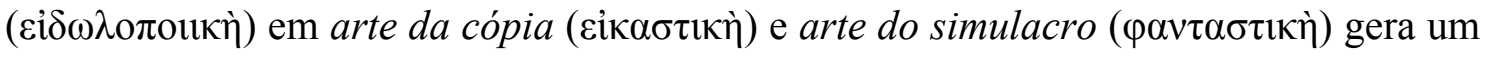
grave problema, ou seja, nos joga diretamente para a compreensão de que a indistinção entre a noção de coisa $(\tau \imath)^{14}$ e a noção de ser (őv) impedia a existência de qualquer falsidade, seja como imagem ou como discurso. Para apresentarmos o problema, será útil nos utilizarmos da leitura lógico-ontológica de Antístenes como modelo ou referência para a vertente interpretativa do eleatismo que Platão visava combater com o diálogo Sofista ${ }^{15}$.

Ao nosso ver, é possível dizer que ao final do diálogo tal distinção entre algo e ser já terá sido consolidada, indicando na junção das coisas uma possibilidade, e não uma

\footnotetext{
${ }^{13}$ Em oposição ao livro X da República, que parece só permitir a possibilidade de uma má mimese.

${ }^{14}$ A palavra grega " $\tau \iota "$ pode ser traduzida por "coisa" ou por "algo". Utilizaremos das duas traduções desta palavra, escolhendo uma delas conforme as necessidades da frase em português.

${ }^{15}$ É possível que o debate do Sofista fosse antes com a vertente eleática presente nos textos atribuídos a Górgias, vertente essa que poderia ter se expressado na posição de Antístenes. No entanto, não estaríamos em condições, por hora, de investigar os pormenores de uma investigação de tal porte para confirmar tal hipótese. Posto isso, a referência a Antístenes parece ser suficiente para nosso intuito.
} 
implicação necessária, para atingir o ser. Desta maneira podemos nos posicionar utilizando como referência o belo texto de Pierre Aubenque sobre o Sofista (AUBENQUE, 1991): se, por um lado, seguimos Aubenque na reconstrução da grande aporia gerada pela indistinção entre coisa e ser, por outro, discordamos quanto à acusação de que Platão não operou a separação entre tais termos no Sofista (para Aubenque, teria sido apenas com os estóicos que esta separação foi operada).

No segundo capítulo trataremos da divisão dialética de Platão. Sabemos que duas versões do dialético haviam sido expostas no Fedro (266b3-c1): aquele que divide segundo as articulações naturais e aquele que reúne por meio de uma visão de conjunto. No limite, estas duas versões parecem ser duas faces de uma mesma moeda que, se complementando, operam a passagem do um ao múltiplo (divisão) e do múltiplo ao um (visão sinóptica), guiadas, no caso do Sofista, por meio de uma maneira específica de compreender a noção de oposição. Veremos que a possibilidade de um simulacro (imagem ruim) e de uma boa imagem que faça referência ao $\operatorname{ser}^{16}$ será garantida, para Platão, a partir da utilização de um novo método ou caminho a ser percorrido: partir das coisas dadas e, após especificá-las em suas partes, subir em direção ao ser, identificando linhagens. Se quisermos ainda nos utilizar dos termos eternizados por Parmênides, poderíamos dizer que este caminho esmiúça a opinião $(\delta o ́ \xi \alpha)^{17}$ para partir com fluidez

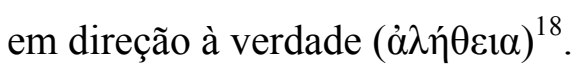

Essa passagem nos conduzirá ao tipo aparentemente novo de dialética que

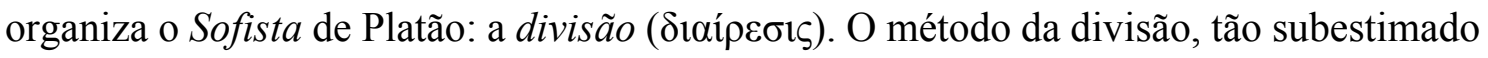

\footnotetext{
${ }^{16}$ Vale notar que Platão não parece abandonar a premissa eleática que postula que "dizer o verdadeiro é dizer o que é".

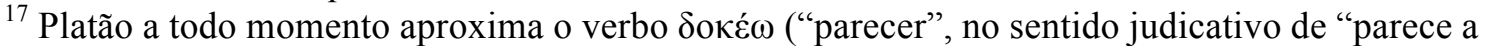
fulano que...") do verbo paívouar ("aparecer", no sentido fenomênico), como por exemplo na

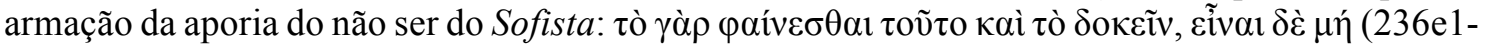
2). Tal aproximação frequente, no contexto deste diálogo, nos conduz a identificar uma interpretação fenomênica da $\delta$ ó $\xi \alpha$ parmenídica, por parte de Platão (como veremos no primeiro capítulo, era possível ver algo desta leitura platônica na passagem dos livros V para o VI da República platônica). De qualquer modo, mesmo que estejamos forçando a barra no cotejo do Poema de Parmênides com o texto platônico, Néstor-Luis Cordero identifica que tal leitura platonizante da $\delta o ́ \xi \alpha$ de Parmênides já estaria consolidada nos escritos neoplatônicos de Simplício. Segundo o pesquisador franco-portenho, Simplício anacronicamente enxergava o Poema de Parmênides através de uma série de dicotomias platônicas, pois, somente após a sofística, a palavra $\delta$ ó $\xi \alpha$ deixou de ser entendida apenas como "opinião" ou "ponto de vista" e passou a ser compreendida também como "aparência" (CORDERO, 2013a; CORDERO, 2015).

18 "For Plato, doxa can be true, while for Parmenides the fundamental disjunction had been either doxa and thuth" (CORDERO, 2013b, p. 191)
} 
por Gilbert Ryle, parece ser a via de acesso privilegiada não só para compreender o que é um sofista, mas também para entender o funcionamento e o lugar ocupado pelos gêneros supremos na ontologia platônica do Sofista, bem como para elucidar o processo por detrás da forma proposicional de um discurso que se pretenda verdadeiro ou falso. Ryle, no entanto, enxerga a dialética platônica apenas como um debate entre interlocutores interessados (RYLE, 1966, Cap. IV). Para compreender a estrutura proposicional, Ryle se vale da comparação da relação entre nomes e verbos de um enunciado com a de letras e sílabas ${ }^{19}$ de uma palavra (RYLE, 2009 [1960]), sem ver nenhuma ligação desta relação com o método dialético da divisão.

No entanto, a divisão dialética, sendo estabelecida segundo a natureza das coisas

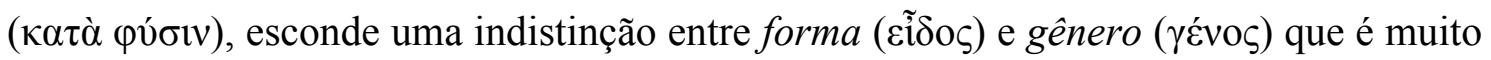
elucidativa para compreensão da ontologia do Sofista ${ }^{20}$. Cabe ao dialético, neste caso, mostrar e enumerar os intermediários da hierarquia dos gêneros, produzindo o múltiplo a partir do uno, ou seja, iniciar a divisão de um gênero superior do qual podemos conhecer sua natureza (por exemplo, a arte da produção) e, dissecando-o nas divisões, ir em direção à determinação da coisa pretendida (no caso deste diálogo, do sofista). Ao enumerar as mediações entre os gêneros, Platão "trava" a indefinição recursiva identificada na teoria das formas pelo argumento do terceiro homem, proporcionando uma via pavimentada para trafegarmos entre os diversos graus de ser. É desta maneira que Platão parece

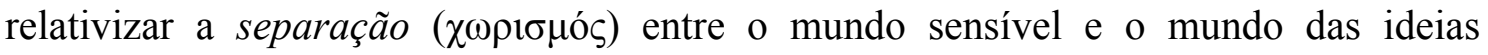
(CORDERO, 2013b), estabelecendo uma metodologia que opere uma passagem mediada entre a hierarquia dos gêneros. Assim, Platão pode mostrar que um gênero inferior (por exemplo, o sofista) participa de um gênero superior (no caso, da arte da produção): tal conjunção possível de um gênero inferior num gênero superior é o que filósofo ateniense chamará de participação ( $\mu \varepsilon \dot{\theta} \varepsilon \xi \xi \iota)$.

No entanto, para que a composição ou divisão de um gênero superior não seja simplesmente arbitrária, Platão parece propor uma noção de oposição bem particular,

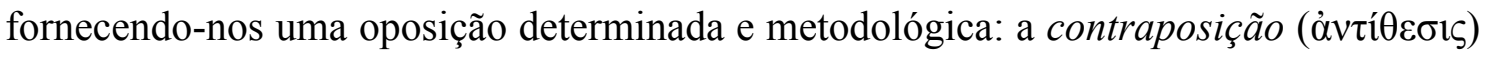
utilizada pela dialética fornece uma opção metodologicamente viável e construtiva tanto

\footnotetext{
${ }^{19}$ Inúmeras vezes a relação entre letras e sílabas é citada por Platão em referência à arte dialética (Sofista, 253a e 261d; Teeteto, 202e; Político, 277d-e; Filebo, 17a-b).

${ }^{20}$ Sobre o método da divisão e sua relação com a ontologia: Plato's method of division (MORAVCSIK, 1973).
} 


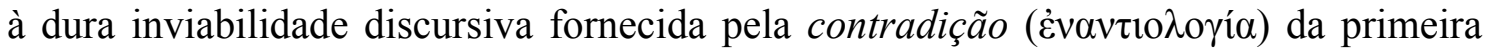
aporia (236e), quanto à controvérsia ( $\dot{\alpha} v \tau \imath \lambda \mathrm{o}$ jía) vaidosa e inócua dos erísticos. A contraposição $(\dot{\alpha} v \tau i ́ \theta \varepsilon \sigma ı)^{21}$ estabeleceria um tipo de alteridade que abre possibilidade para a comunidade entre gêneros ou formas diferentes. Daí a nova ontologia: para serem verdadeiras as formas não teriam mais de ser completamente irredutíveis e disjuntas entre si, agora a alteridade e a conjunção entre as formas são mesmo condição para o verdadeiro $^{22}$.

O estudo da dialética do segundo capítulo nos dá instrumentos justamente para compreender a relação entre os gêneros supremos. Além disso, permitirá ir à procura da concepção de discurso e de imagem elaboradas no Sofista. Do mesmo modo, a formulação de uma nova teoria da boa mimese, ao lado da possibilidade de atribuir à má mimese um estatuto ainda mais seguro que aquele da República $X$, passa a tomar contornos mais definidos. Esta será a conjunção de temas do terceiro e último capítulo da dissertação: a solução das duas aporias do início do diálogo a partir de uma teoria do ser, da imagem e do discurso.

No Sofista (252a), é afirmado que tanto o movimento quanto o repouso, que farão parte mais a frente dos chamados gêneros supremos, participam do ser, apesar de não serem misturáveis entre si. Ou seja, aparentemente, o que Platão está dizendo seria que cada um dos gêneros opostos participa do existente. Deste modo, não teríamos que relegar um dos lados da oposição a um puro não ser. A afirmação, somada a definição de não ser como alteridade (256e), dá a entender, para a teoria platônica do Sofista, existiram diferentes cadeias hierárquicas, todas se encontrando na unidade do ser.

Quanto ao discurso, este é sempre imagem ou figuração da cadeia dos seres: quando o discurso reproduz fielmente o segmento da cadeia, mimetiza o ser e, portanto, é um discurso verdadeiro; caso ele reproduza algo diferente da configuração de tal cadeia, temos um discurso falso ou o simulacro. Acreditamos que é por isso que o discurso, para

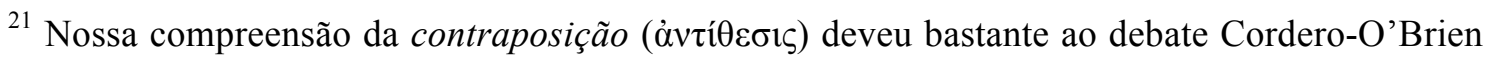
sobre Sofista, 258a11-b4 (PLATON, 1993, nota 330; O’BRIEN, 1999, pp. 27-28)

${ }^{22}$ Vale dizer que a oposição entre gêneros não se dá necessariamente em duas partes, ou seja dicotomicamente. No entanto, para Platão, parece ser mais belo ou perfeito que uma boa divisão assim o faça: para este assunto, consultar Político (262e). De qualquer modo, certo é que, ao

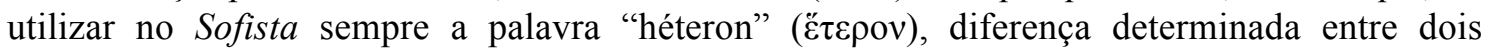

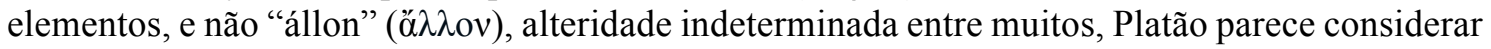
preferencialmente divisões ditas dicotômicas. A dicotomia é marcada de maneira ainda mais forte

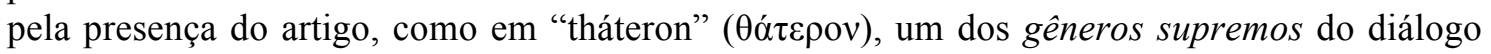
(por exemplo, Sofista 255a1).
} 
que tenha sentido e possa ser bivalorado, tem de apresentar a mesma estrutura da tessitura do ser, isto é, a mesma forma: esta é o que está por detrás do que se chamará adiante de forma lógica. Serão, todavia, os conteúdos da cadeia de seres em questão encadeados corretamente ou não que determinarão a sua verdade ou a sua falsidade. $\mathrm{O}$ discurso falso, ao não mimetizar corretamente, está desligado da cadeia do ser, é o outro do ser, mas não o não ser: este último, Platão concordaria, por definição não existe.

É deste modo que, aparentemente, para Platão, a totalidade das coisas do mundo podem ser ligadas através de uma pletora de linhagens, mas todas estas linhagens deveriam a princípio levar ao ser. Portanto, todas as coisas são emanações ou imagens de um ser que unifica a multiplicidade. Não poderemos, desta maneira, aceitar a leitura, dita categorial: de que os gêneros supremos sejam subconjuntos da proposição, ou diferentes tipos de elementos que constituem o enunciado, com a função de exercer, de maneira independente, um papel formal sobre os elementos do discurso. De outro modo, posto que são gêneros superiores, isto é, por estar em posição mais alta na hierarquia dos gêneros, logo, toda a multiplicidade de gêneros que estão abaixo deles é regida e afetada pela sua força ontológica: nisto está sua função formal, pois são os gêneros inferiores que são subconjuntos dos superiores.

Esta compreensão da teoria lógico-ontológica do Sofista nos permitirá interpretar as 7 divisões que pretendem definir a figura do sofista: as 6 primeiras definições eram corretas apenas parcialmente. Será somente na sétima e última definição, como produtor de ilusões (268c-d), que podemos compreender completamente a figura do sofista: ele produz mal, ou seja, é, e ao mesmo tempo faz, uma cópia malfeita. O sofista não copia a cadeia dos seres, ilude e finge copiar, não aspira ao ser. Numa interpretação possível, mas um pouco violenta com o texto platônico, poderíamos dizer que, dado que somente os deuses são sábios ( $\sigma \circ \varphi o ́ \varsigma)$, o filósofo (

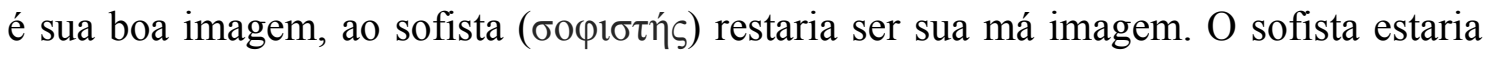
para o filósofo assim como o lobo está para o cão.

É curioso que, se passarmos os olhos sobre os trabalhos que tratam de Platão especialmente ao longo do século XX, veremos uma enorme profusão de scholars dedicados ao Sofista. No entanto, as interpretações do Sofista ao longo deste século se concentraram na grande maioria das vezes na sua parte lógica-ontológica (236e-264). Não seria por acaso. Nesta seção, que parece ser um enorme apêndice a uma das definições de sofista presentes no diálogo, está o que se poderia dizer ser o sistema 
filosófico do diálogo. Nesta parte também parece estar o que há de mais interessante para questões próprias do mundo contemporâneo: seja a crise da ontologia e da metafísica ou sua pretensão de refundação, seja a nossa vivência corriqueira rodeada e transpassada por uma profusão de imagens e simulacros, seja a liberdade de formalizar sistemas lógicos que rigorosamente não se utilizam da bivaloração. Será deste modo que, neste trabalho, buscaremos nos dedicar também, mais uma vez, a compreender esta parte do diálogo, tão sistemática quanto obscura, que cumpre a função de particularizar o Sofista no interior da obra platônica como um diálogo que apresenta uma tese final aparentemente definida e bem-acabada. Não aceitaremos, todavia, a opção de tratá-lo como um simples sandwich (RYLE, 1966, pp. 139-140). Pretendemos, pelo contrário, começar a juntar as complexas peças deste complicado quebra-cabeças que é o Sofista de Platão: ficará claro ao final desta dissertação que este é um duríssimo e importante trabalho ao qual esta dissertação certamente não está à altura, e se mostra apenas como um simples indicativo de caminho.

É evidente que a "leitura filosófica" de Ryle pode muito bem ser prolífica para a discussão contemporânea, não ousamos dizer o contrário. No entanto, de modo geral, colocamos nossas fichas na crença de que valorizar o desnível histórico entre o pensamento ontológico grego e o contemporâneo seja mais elucidativo para a compreensão de nosso mundo atual que marcar suas superficiais concordâncias de essência. Como disse certa vez Pierre Aubenque: "certo é que os gregos sabiam de outra maneira que nós" ${ }^{23}$. Esperamos que este trabalho tão restrito ao Sofista de Platão ajude a fortalecer tal posição histórico-filosófica. Afinal de contas a história não é feita somente das heranças, mas também dos constantes parricídios que não cessamos de operar.

23 "Ce qui est sûr, c'est que les Grecs savaient autrement que nous" (AUBENQUE, 1992, p. 2425) - o grifo é do autor. 


\section{A APORIA DE ELEIA}

Parricídio. Em que consistiria isso? O ato de assassinar o próprio pai sempre se mostrou como um fato intrigante, afinal não é algo muito aceito pela nossa sociedade. De fato, é algo chocante o suficiente para não ser mencionado de modo leviano, todos os dias. Entretanto, apesar dos juízos morais que o cercam, o que nos interessa aqui é principalmente esta palavra, que parece em si mesma contraditória: é certo que, mesmo após o filho ter matado o próprio pai, aquele ainda continua a ser filho deste. Ou seja, assassinar o próprio pai não revoga atestado de paternidade algum. Portanto, certo é dizer que duas coisas diferentes ocorrem nesta contrariedade: há realidade tanto na morte do pai assassinado, quanto na herança genética deixada pelo progenitor, ainda presente em cada parte do filho. Separando deste modo, podemos dizer que em qualquer parricídio está envolvido um jogo de rupturas e continuidades com as quais o assassino terá sempre que lidar.

É justamente da palavra "parricida" ( $\pi \alpha \tau \rho \alpha \lambda o$ ó́ $)$ que Platão, na boca do Estrangeiro de Eleia (241d3), se vale para representar sua própria condição no diálogo Sofista. Ao consolidar a instituição de uma forma proposicional, bem como uma nova maneira de compreender as noções de ideia e de alteridade, o saldo lógico-ontológico deste diálogo parece se desdobrar pela história da filosofia assim como a desgraça do parricida Édipo sobre seus descendentes ${ }^{24}$.

Ao considerar o diálogo de um ponto de vista lógico, podemos dizer que o Sofista trata, principalmente, da análise das condições de possibilidade para a existência de discursos verdadeiros e de discursos falsos. Com o objetivo de identificar tais condições, veremos que no diálogo foram realizadas uma série de reviravoltas ontológicas que seriam necessárias para que dois valores de verdade (Verdadeiro ou Falso) pudessem ser atribuídos a uma sentença. É, portanto, no diálogo Sofista que podem ser identificados os

\footnotetext{
${ }^{24}$ A começar pelas semelhanças com a forma proposicional apresentada por Aristóteles no capítulo V do De Interpretatione (17a9-12; 17a17-20): "Há necessidade de que todo discurso declaratório decorra do verbo ou de um caso dele. Com efeito, o discurso do homem, se não lhe for aposto o 'é', o 'será' ou o 'foi' ou alguma coisa desse tipo, ainda não é discurso declaratório" (ARISTÓTELES, 2013, p. 7); ou "Seja, portanto, apenas uma fórmula de expressão o nome e o verbo, uma vez que não é possível, por sons articulados, a exprimir somente um deles, acertar de maneira que se chegue a um discurso declaratório, como quando alguém pergunta ou não, mas outro dá seu próprio julgamento" (ARISTÓTELES, 2013, p. 9).
} 
pressupostos ontológicos sedimentados no interior da primeira formulação do célebre princípio lógico da bivalência ${ }^{25}$. No Sofista, é possível dizer, está sendo operado o trabalho que nos levará, pela primeira vez, em direção à realização de uma semântica proposicional $^{26}$.

Também será necessário notar, entretanto, que Platão realiza uma importante aproximação entre imagem e discurso que não pode ser relegada a segundo plano. Para o filósofo de Atenas, qualquer discurso válido, por se referir a algo exterior a ele mesmo, deve ser tratado como um tipo de imagem. Em outras palavras, todo discurso significativo se pretende como imagem de algo. Será por conta desta referência a algo, seja da imagem visual, seja da discursiva, que se justificará a discussão propriamente ontológica do diálogo. Do ponto de vista imagético, o intuito do diálogo é distinguir e garantir filosoficamente a existência de imagens boas e de imagens ruins.

Assim, podemos dizer que buscaremos compreender os movimentos lógicoontológicos operados por Platão no Sofista e, em paralelo, pois parecem ser duas faces da mesma moeda, não poderemos deixar de investigar a sua controversa relação com a filosofia de Parmênides. Afinal de contas, antes de tudo, é na trilha do vocabulário ontológico formulado em Eleia que se trava a discussão estabelecida pelo diálogo Sofista. Mais do que isso, não podemos deixar de notar que as duas aporias identificadas pelo Estrangeiro podem e devem ser compreendidas como a exposição de paradoxos cuja origem remonta à tradição filosófica iniciada por Parmênides no século V. Ou seja, em resumo, o diálogo Sofista seria a discussão a respeito da identificação de possíveis inconsistências teóricas no interior do eleatismo, bem como responsável pela apresentação de uma proposta de resolução para elas.

\footnotetext{
${ }^{25}$ Tomamos a liberdade de utilizar do termo "princípio de bivalência" para nos referir à dupla valoração de um enunciado. Porém, como indica Balthazar Barbosa Filho (primeira nota de seu artigo "Aristóteles e o princípio da bivalência"), o termo foi empregado originalmente por Jan Łukasiewicz, em 1920, fazendo referência ao que era exposto no Da Interpretação (IV, 17a2-3), de Aristóteles. O texto de Łukasiewicz está no anexo a Observações filosóficas sobre os sistemas de cálculo proposicional multivalentes (ŁUKASIEWICZ, 2013, p. 128).

${ }^{26}$ Pelo termo "semântica proposicional" pretendemos designar a abordagem lógica que privilegia a identificação dos termos proposicionais (como os nomes e os verbos) e de seus respectivos correlatos, assim como da relação entre o signo proposicional em seu conjunto (a conjunção dos termos proposicionais) e o referente ao qual a proposição pretende significar. Grosso modo, na obra platônica, esta abordagem semântica não parecia ainda ter sido destinada às proposições, mas apenas aos nomes. Além da semântica teríamos também a abordagem sintática (GRANGER, 1979, pp. 149-150), esta última visaria fazer jus à relação entre os signos (deste modo a silogística aristotélica diria respeito, portanto, à sintaxe lógica). Ficará claro mais afrente nossa compreensão de que, no Sofista de Platão, a proposição é considerada como um signo que imita alguma coisa.
} 
O debate com o eleatismo pode mesmo ser visto no personagem mais proeminente do diálogo: o Estrangeiro de Eleia. É possível dizer que essa personagem condutora do diálogo carrega em si mesma a ambiguidade proveniente da apropriação dos textos da escola de Eleia. A desconfiança com relação a sua idoneidade é bem marcada no início do diálogo (216a-217a). Não sabemos exatamente o que esperar daquele que chega da cidade de Eleia: podemos estar diante tanto de um filósofo quanto de um sofista ${ }^{27}$.

Neste primeiro capítulo, portanto, trataremos de (i) evidenciar a origem eleática das aporias do diálogo, (ii) apresentar a aporia do não ser (236e) e a do ser (251a-b), assim com (iii) identificar como o problema eleático se desbobra a partir de algumas considerações platônicas a respeito da noção de mimese e de imagem. Acreditamos que somente este trabalho preliminar de reconstituição histórico-filosófica do problema abordado no diálogo poderá fazer com que as fraturas da filosofia platônica com relação ao eleatismo sejam diagnosticadas e o propósito do diálogo possa ser compreendido em sua inteireza.

Acreditamos que o adjetivo "parricida" possa ser utilizado como uma espécie de mote para a leitura do diálogo. De algum modo, neste termo estariam presentes as torções conceituais que marcam a leitura que um sistema filosófico faz de um outro (no caso, a leitura que Platão faz do Poema de Parmênides) - passagens estas que conferem ao sistema filosófico um caráter fundamentalmente histórico. Desta maneira, podemos ver, por meio dessas metamorfoses, a emergência de problemáticas filosóficas que até então eram inexistentes e não imaginadas pelo sistema filosófico anterior. Posto isso, podemos dizer que, na imanência de um discurso filosófico, nunca podemos nos abster do impulso de inventariar os vários tipos de heranças que nossos pais, mortos ou não, deixaram para nós. Este é o trabalho que, para nós, assumimos como o de um historiador da filosofia.

A explicação do termo "parricida", requisitada por Teeteto, é dada pelo Estrangeiro de maneira programática:

\footnotetext{
${ }^{27}$ Para uma análise mais completa da a figura do Estrangeiro de Eleia, ver o livro de Jean-François Mattéi (MATTÉI, 1983).
} 
Que, para nos defendermos, ser-nos-á necessário pôr à prova o discurso do nosso pai Parmênides e impor-lhe pela força que o que não é de certo modo é e que por sua vez também o que é de algum modo não é. ${ }^{28}$ (Sofista, 241d5-7)

De fato, será exatamente de justificar que o ser de certo modo não é, e que o não ser de certo modo é, que o diálogo se ocupará até 264c. Consideremos a seguinte divisão do diálogo Sofista, estruturada a partir das 7 definições $^{29}$ que o Estrangeiro dá à figura do sofista $^{30}$, objeto do diálogo em questão, com o objetivo de localizar no texto platônico o momento no qual o atentado contra o pai aparece:

I - Caçador interesseiro de jovens ricos (222a-223b);

II - Comerciante em ciências (223c-224d);

III - Comerciante de primeira mão de ciências, como produtor (224e);

IV - Comerciante de segunda mão de ciências, não como produtor (224e);

V - Erístico mercenário (225a-226a);

VI - Refutador e purificador de almas (226a-231b);

VII - Imitador de artes, produtor de ilusões e perplexidade (233d-236e, com continuação em 264c-268d).

A condição de parricida do pai Parmênides é confessada no interior da sétima definição, definição que se inicia em 233d, é interrompida em 236e, e retomada a partir

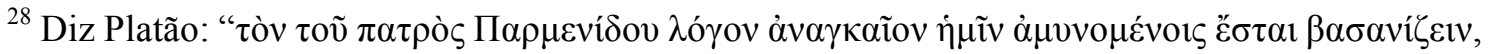

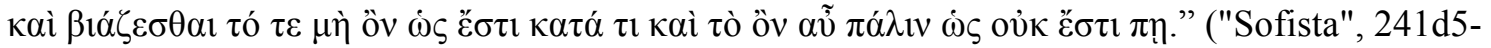
7)

${ }^{29}$ Utilizaremos o termo definição devido à falta de um melhor. Na verdade Sócrates pergunta ao Estrangeiro se os nomes sofista, político e filósofo corresponderiam a um, dois ou três gêneros. $\mathrm{O}$ vocabulário próprio à definição utilizado no início do diálogo, bem como o fato da questão ter sido colocada por Sócrates, indicariam uma proximidade com o procedimento definitório. No entanto, Platão não parece estar pretendendo encontrar a essência do sofísta, mas apenas identificar a atividade relacionada ao uso da palavra "sofista". É também possível que o objetivo pretendido seja tão somente localizar o sofista na trama das atividades técnicas. Para a defesa de um ponto de vista definitório do método da divisão, mas que não consegue se concretizar devido ao fato da sofística não ser propriamente uma técnica, ver BROWN, 2010.

${ }^{30}$ Apesar do Estrangeiro contar seis definições do sofista em 231c9-e6, às quais é acrescentada a última, contabilizando sete ao total, pelo texto parece ser perfeitamente possível admitir que o que seria a segunda, terceira e quarta definições, seja uma só com duas subdivisões.
} 
de 264c. Deste modo, portanto, parece ser possível compreender o trecho entre 236e e 264c (que corresponde a pouco mais da metade do diálogo) como um enorme apêndice à sétima definição do sofista, justamente sob o jugo de tal acerto de contas com a figura de Parmênides. Em outras palavras, pode-se dizer que entre 236e e 264c será cumprido o programa enunciado em 241d5-7: impor que, de algum modo, o ser não seja e o não ser seja.

Pois, a menos que estas coisas [que o que não é de certo modo é, e que o que é de certo modo não $e^{31}$ ] tenham sido refutadas ou aceites, alguém poderá, em algum momento de lazer, ao falar a respeito do discurso falso ou da opinião falsa quer do simulacro, quer da imagem, quer da imitação, quer das aparências, ou mesmo a respeito das muitas artes que há acerca dessas coisas, não ser ridicularizado, ao ser forçado a contradizer-se a si mesmo ${ }^{32}$ (Sofista, 241e1-6)

De fato, as dificuldades apresentadas no diálogo para noções tais como a de simulacro ou de discurso falso podem ser remetidas a uma aporia de origem eleática. Como seria possível instaurar uma imagem daquilo que não é? Não seria condição para imagem ser imagem de algo que é? E quanto ao discurso, o fato de se referir ao que é não seria uma condição para a sua própria existência? Mas tal condição, ou seja, a aparente necessidade da imagem e do discurso se referenciarem ao ser, já não garantiria a qualquer discurso ou imagem o estatuto de verdadeiro? As perguntas próprias ao diálogo partem da completa dissociação entre ser e não ser por parte da filosofia de Eleia. Desta separação estrita entre ser e não ser, típica do eleatismo, o sofista aparentemente concluiu: não existem nem imagens, nem discursos falsos ${ }^{33}$.

\footnotetext{
${ }^{31} \mathrm{O}$ discurso de Parmênides negava tal possibilidade. Assim, o que está em jogo é o consentimento ou refutação das palavras do grande Parmênides (241d5-7). O dito de Parmênides está exposto em $237 \mathrm{a} 8-9$.

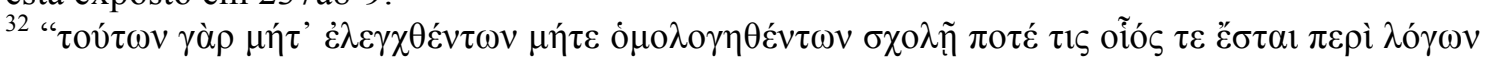

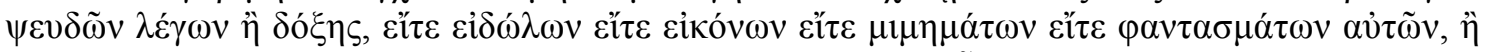

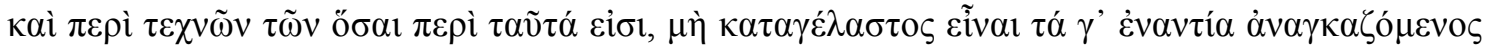

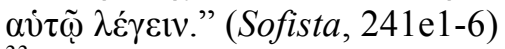

33 "O discernimento dessas condições [condições lógicas e ontológicas do discurso proposicional tal como formuladas pelo Estrangeiro de Eléia no Sofista] tem como motor o intuito de dissolução de um paradoxo de origem sofística, que põe em linha de fogo a própria possibilidade do discurso
} 
Temos pelo menos dois indicativos de que a aporia tratada do Sofista não é uma novidade, uma contradição encontrada pelas reflexões do próprio Platão, mas sim um problema antigo, já trabalhado e retrabalhado por filósofos antecessores, e ao qual Platão pretende nos oferecer uma solução nova e original. Podemos ver, por algumas vezes, o testemunho de que Platão fazia referência a uma questão já antiga.

Em 236e2-3, ao apresentar a primeira aporia do diálogo (chamada de aporia do não ser), Platão não deixa de acrescentar que "tudo isso está cheio de dificuldades o tempo todo, tanto no passado, quanto agora" ${ }^{34}$. Aristóteles, numa passagem da Metafisica em que comenta o Sofista de Platão (Met. N 2), também se mostra consciente do histórico desta problemática a respeito do ser e do não ser. Ao "problematizar antiquadamente"

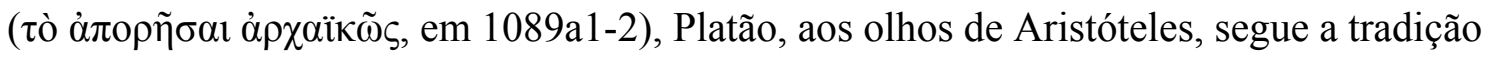
de Eleia e apresenta o problema nos mesmos termos em que aquele foi apresentado por Parmênides $^{35}$. Mas que termos arcaicos são estes dos quais Aristóteles discorda? O Estargirita faz uso da mesma citação do Poema de Parmênides utilizada por Platão no Sofista (237a8-9):

"Não, impossível que isto prevaleça, ser (os) não entes

Tu porém deste caminho de investigação afasta o pensamento;" 36

(Parmênides, DK B 7, 1-2. Tradução de José Cavalcante de Souza com alterações)

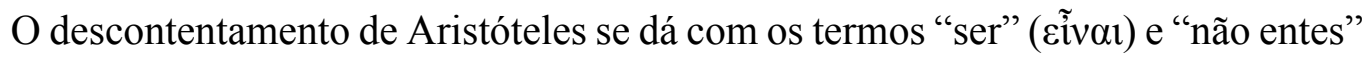

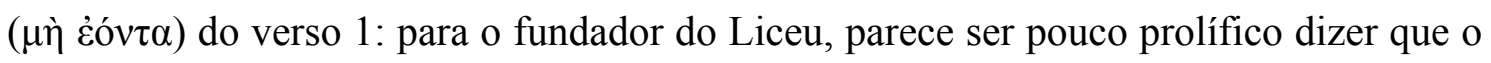

proposicional. Adaptado de um argumento de Parmênides, pretende demolir o conceito de discurso falso" (LOPES DOS SANTOS, 2010, p. 18).

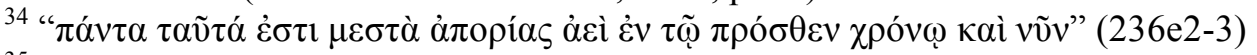

35 "Que la lignée Parménide-Platon-Aristote soit à l'origine d'une figure de pensée que diviendra plus tard dominante sous le nom de 'métaphysique' ne doit masquer le fait que cette orientation 'ontologique' reste relativement isolée non seulement dans l'histoire de la pensée en général (qu'on songe à sa totale absense dans les systèmes de pensée non occidentaux), mais même dans la pensée grecque, qui a été pourtant le lieu incontestable de son surgissement.

Ainsi Parménide est-il le seul penseur présocratique à s'intéresser à l'être. Si c'est seulement par abus de langage que l'on peut parler d'une ontologie d'Héraclite, d'Empédocle ou d'Anaxagore, il est vrai en revanche que Parménide est, avant la lettre, un penseur onto-logique." (AUBENQUE, 1987, p. 104.)

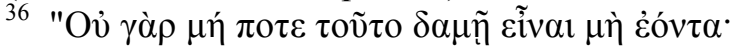

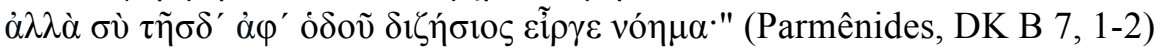


não ser deve de algum modo ser. Afinal, diz o fundador do Liceu, se de muitas maneiras se diz o ser, também de muitas maneiras é dito o não ser (Met N 2, 1089a15ss), ou seja, os termos "ser" e "não ser" fariam tábula-rasa de uma complexidade subjacente ${ }^{37}$.

Poderíamos observar, com a ajuda desta passagem da Metafísica, que a crítica dirigida por Aristóteles contra Platão e Parmênides se, por um lado, direciona a doutrina aristotélica das categorias para rebater o modo como Platão e Parmênides formulam sua problemática, por outro, nos dá um importante testemunho da herança lexical transmitida do Poema para o Sofista de Platão. Em suma, diríamos que ao realizar o parricídio Platão se volta contra o interdito promulgado em Eleia, mas, ao mesmo tempo, aceita aqueles termos impostos pelo pai de Eleia.

Devemos observar que, de maneira diferente daquela aristotélica, é também contra este mesmo trecho do Poema de Parmênides, citado duas vezes no Sofista (em 237a8-9 $9^{38}$ e 258d2-3), que Platão pensa estar se voltando ao operar o parricídio:

"Que, para nos defendermos [da aporia do não ser], ser-nos-á necessário pôr à prova o discurso do nosso pai Parmênides e imporlhe pela força que o que não é de certo modo é e que por sua vez também o que é de algum modo não é." ${ }^{39}$ (Sofista, 241d5-7)

Ao realizar o atentado contra o pai, Platão parece acreditar estar se enveredando por aquele que costuma ser identificado como o caminho (ódós) que coage não entes a ser, isto é, trilha o caminho da mistura entre ser e não $\operatorname{ser}^{40}$. Platão, no Sofista, se contraporá, portanto, ao postulado presente no verso 1 do fragmento 7, buscará garantir que o que não é de algum modo seja, bem como que o que é de certo modo não seja.

O pequeno trecho de dois versos do Poema exposto no Sofista (237a8-9) apresenta muitas das questões fundamentais que nos permitirão propor a identificação de uma possível análise platônica para a filosofia de Parmênides como um todo. No segundo verso $(\mathrm{DK} 7,2)$ é exposto o termo a partir do qual poderemos começar a desdobrar a

\footnotetext{
${ }^{37} \mathrm{Na}$ crítica aristotélica de Met. N 2 fica claro que, para Aristóteles, a resolução por meio da teoria das categorias não é utilizada por Platão no Sofista. O testemunho vai justamente contra a linha interpretativa encabeçada por Ryle (RYLE, 2009 [1939], p. 37; 2009 [1960], p. 70-71).

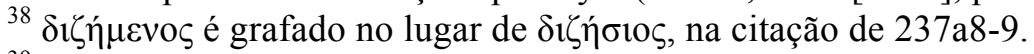

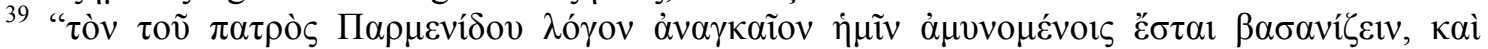

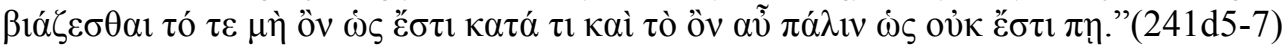

${ }^{40} \mathrm{O}$ Estrangeiro pretende refutar ( $\dot{\varepsilon} \lambda \dot{\varepsilon} \gamma \chi \varepsilon \mathrm{\varepsilon} v$ ) a tese de Parmênides a partir de $242 \mathrm{~b}$.
} 
questão de como o conteúdo de tal citação se posiciona no interior da filosofia eleática: seria necessário, para Parmênides, que nos afastássemos de um certo caminho de

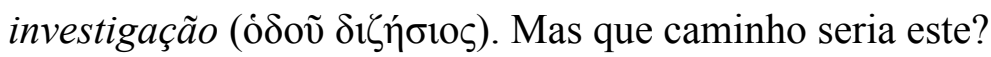

Sem dúvida o caminho (ódós) do segundo verso do fr. 7 faz referência ao segundo caminho expresso no fr. 2, 6 do Poema:

"os únicos caminhos de inquérito que são a pensar:

o primeiro que é e portanto que não é não ser, de Persuasão é o caminho (pois à verdade acompanha); o outro, que não é e portanto que é preciso não ser, este então, eu te digo, é o atalho completamente desinformado; pois nem conhecerias o que não é (pois não é exeqüível), nem o dirias..."41 (Parmênides, DK B 2, 2-8. Tradução de José Cavalcante de Souza com modificações)

Tais caminhos de investigação seriam os únicos - confiramos a devida ênfase ao

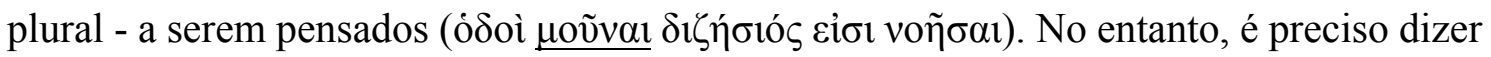
que o segundo caminho não seria de fato impossível de ser traçado, ele é sim de todo desinformado, inteiramente desorientado $(\pi \alpha v \alpha \pi \varepsilon v \theta \varepsilon \dot{\varepsilon} \alpha)$. A tradução da palavra “ $\pi \alpha v \alpha \pi \varepsilon v \theta \varepsilon \dot{\varepsilon} \alpha$ " por "inteiramente inviável" 42 talvez não capte a nuance fundamental para a compreensão filosófica: "inviável” daria a entender que este é um caminho que não seria possível de traçar e que, por exclusão, só haveria um caminho aberto ao pensamento - aquele do ser. Ao traduzir " $\pi \alpha v \alpha \pi \varepsilon v \theta \varepsilon \dot{\varepsilon} \alpha$ " por "completamente desinformado",

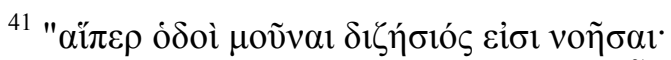

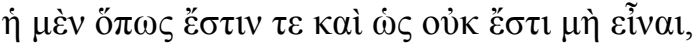

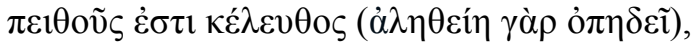

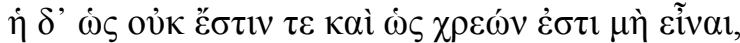

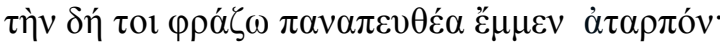

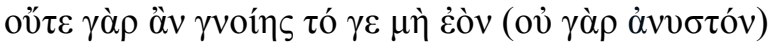

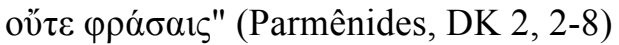

${ }^{42}$ O termo $\pi \varepsilon v \theta \dot{~ s i g n i f i c a ~ e m ~ i n g l e ̂ s ~ " t i d i n g s " ~(L i d d e l-S c o t t, ~ 1996), ~ a l g o ~ c o m o ~ " i n f o r m a c ̧ a ̃ o " ~ o u ~}$ "notícias". Os tradutores vão quase sempre na direção que poderia dar a entender a inviabilidade do segundo caminho: "inteiramente inviável" (Santoro); "de todo incrível", parecendo ler " $\pi \alpha v \alpha \pi \varepsilon(\theta \varepsilon \dot{\varepsilon} \alpha \gg$ com o manuscrito procliano P (Cavalcante de Souza); "em tudo ignoto" (Trindade); "tout à fait inconnaissable" (Cordero); "of which we can learn" (O' Brien); "che non si può scrutare" (Untersteiner); "wholly unknowable" (Tarán). Nossa tradução é mais próxima daquela de A. H. Coxon: "wholly without report".
} 
interpretamos que há uma completa desorientação para aquele que pretende seguir esta difícil vereda, isto é, não há nada que sirva de orientação para aquele que pretende seguir

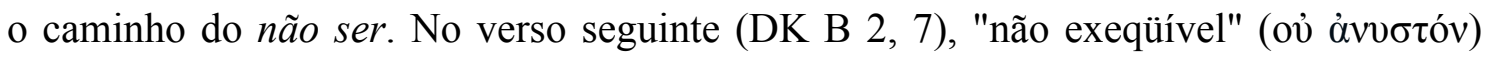

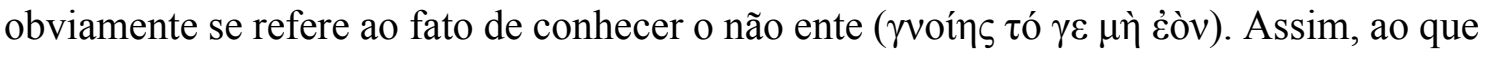
parece, há uma vinculação entre o conhecer e o ente: só se conhece aquilo que é. O não ser seria incognoscível.

Ao final, Parmênides completa o fragmento 2 afirmando que o não ser não poderá

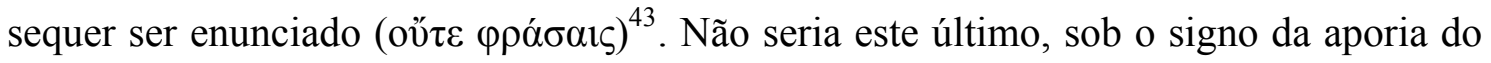
discurso falso, justamente o problema tratado a partir de 236e no Sofista? Nos termos de Parmênides o problema poderia ser exposto da seguinte maneira: como é possível pensar

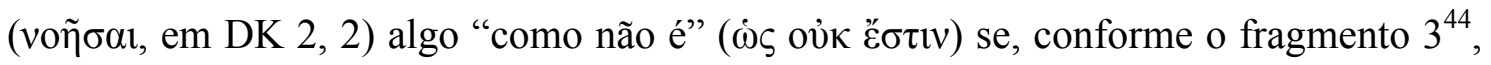
pensar e ser são indissociáveis? No início do Sofista, poderíamos dizer que o postulado da inteligibilidade do ser, expresso no fragmento 3 de Parmênides, está posto em questão.

O problema só pode ser inteiramente compreendido se lembrarmos de mais um postulado de Parmênides: o caminho do ser é o caminho do verdadeiro (DK 2, v. 4; DK 8 , vs. 50-51). O verdadeiro está ligado sempre ao ser e dele é indissociável, ou seja, aceitase o ser como critério para o verdadeiro. Se considerarmos o não ser nem dizível, nem pensável (DK B 8,7-8), estaríamos negando a existência do contrário do verdadeiro, isto é, do falso. Em consequência disso, tudo o que falaríamos, por ser enunciado em referência a um ser, estaria condenado a estar necessariamente sob o valor do verdadeiro. Platão não parece estar disposto a aceitar esta consequência.

Estes parecem ser exatamente os passos seguidos pela interpretação do Poema posta em circulação por Górgias de Leontinos, no seu Tratado do não ser. Dizia Górgias na versão transmitida por Sexto Empírico:

“Um e primeiro, que nada é; segundo, que se é, não é

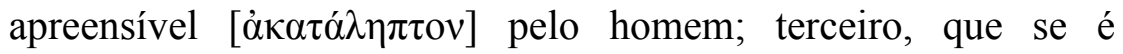

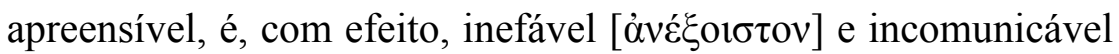

\footnotetext{
43 "Em resumo, podemos concluir que a ontologia de Parmênides resulta de duas bases fundamentais: o princípio de não-contradição forte, que separa completamente ser e não ser, e o princípio de que pensar e dizer é pensar e dizer o ser, O primeiro estabelece que só há dois caminhos de investigação e que e que um deve ser escolhido em detrimento do outro. O segundo determina qual o caminho a ser escolhido. (SOUZA, 2009, p. 34)

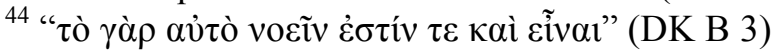




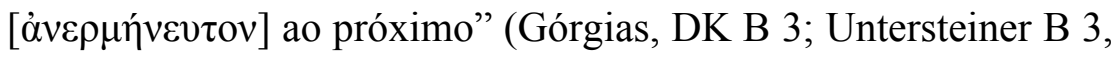
linhas 18-21; Sexto Empírico, Adv. Math. VII, 65-66) ${ }^{45}$

Diz na versão exposta pelo tratado pseudo-aristotélico De Melisso, Xenófanes e Górgias:

"[Górgias] diz nada não ser; se é, é não cognoscível [ă $\gamma v \omega \sigma \tau o v] ;$ se é e também é cognoscível, não é, todavia, transmissível [oủ $\delta \eta \lambda \omega \tau$ òv] aos outros" (Górgias, ed. Untersteiner, fragmento DK B 3 bis, linhas 160-162; Pseudo-Aristóteles, De M. X. G., 979a 10ss.) $)^{46}$

Ao negar qualquer existência ao não ser, Górgias evidencia o abismo entre ser e não ser que pode ser encontrado no Poema de Parmênides (é ou não é ${ }^{47}$ ). Górgias mostraria que, no discurso de Parmênides, se nada é, então tudo é: e este ser deve ser absolutamente monolítico, sem fissuras, partes ou divisões. Caso contrário, estaríamos novamente misturando ser e não ser, não sairíamos desta contradição irresoluta. A meontologia sofística de Górgias trata, portanto, de implodir o Poema do velho sábio de Eleia, destruindo-o por dentro a partir da radicalização de suas próprias teses ${ }^{48}$ : só haveria o caminho do ser, seria um contrassenso haver um caminho de algo que não pode ser dito ou pensado. Na visão de Górgias, ao ser dito, imediatamente o não ser se tornaria ser e o

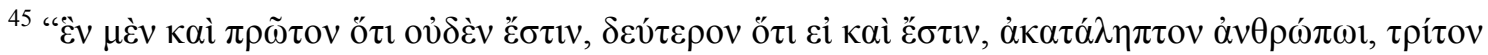

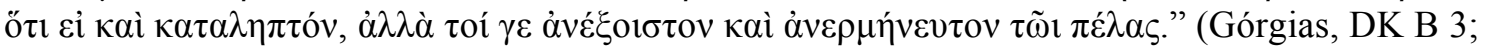
Untersteiner B 3, linhas 18-21; Sexto Empírico, Adv. Math. VII, 65-66). Tradução nossa. Os termos utilizados por Sexto carregam um forte traço das formulações estoicas e céticas. Para a sofística de Górgias, não devemos levar a sério este contexto filosófico específico do período helenístico.

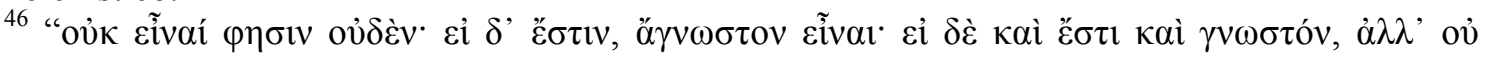
$\delta \eta \lambda \omega \tau$ tòv $\alpha ̈ \lambda \lambda o r \varsigma$ " (Górgias, ed. Untersteiner, fragmento DK B 3 bis, linhas 160-162; PseudoAristóteles, 979a 12ss.). Tradução nossa.

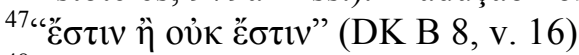

48 “ 'Se Parmênides, então Górgias' significa que, ao tomar ao pé da letra o imperativo do Poema, ao aplicar Parmênides a Parmênides, é o Tratado que se escreve: pois o Tratado não faz senão repetir o Poema, mas de maneira tal que a exigência de identidade, o princípio universal, seja nele efetivamente respeitada. O Tratado é a escrita da falta constitutiva da origem, o que quer dizer que o Poema não é senão a falha do Tratado, falha equívoca já que ele repousa em uma distinção não sustentável, insustentável, entre 'é' e 'não é' " (CASSIN, 2015, p. 70)
} 
discurso passaria a criar realidades ${ }^{49}$. No entanto, a tese de Górgias, por contraste, também levava à inocuidade um discurso completamente engessado nos critérios do ser: revela que ao ser nada poderia ser acrescentado pelo discurso, pois além do ser não haveria coisa alguma.

Assim, o sofista de Leontinos fazia o ontólogo de Eleia cair em contradição. Platão parece não ter deixado de perceber o que estava acontecendo. Não seria mera coincidência o filósofo de Atenas expor o problema do não ser exatamente nos mesmos moldes que o sofista de Leontinos:

“Concordas então que não é possível pronunciar corretamente, nem

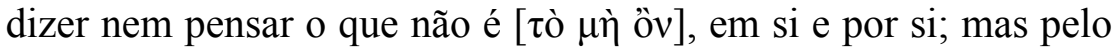

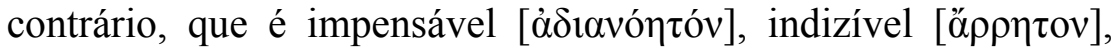

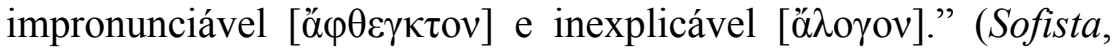
$238 \mathrm{c} 8-11)^{50}$

Com o objetivo de oferecer uma saída para este imbróglio, Platão tentará traçar o caminho desaconselhado pelo pai, porém sem cair em contradição com o próprio discurso: deverá misturar ser e não ser, como na confusão dos mortais de duas cabeças

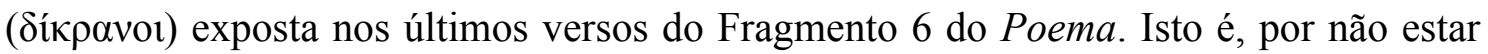
disposto a aceitar como consequência a inexistência do falso, Platão tratará de fazer com que, por meio de tal mistura de ser e não ser, não incorramos num tipo de contradição que leve a condenar o discurso ao silêncio (aporia do não ser) ou à simples tautologia (aporia do ser).

\footnotetext{
${ }^{49}$ Bárbara Cassin especifica: "não que não haja pseudos, mas, de modo mais exato, porque uma mentira, um erro, uma ficção existem tanto quanto o verdadeiro tão logo o proferimos. Se basta ser pensado para ser, e ser dito para ser pensado, então à evidência sensível se substitui o fato de língua: não é, portanto, o ente parmenidiano, mas de igual modo e indiscernivelmente, o não-ente, que nos é assim acessível." (CASSIN, 2005, p. 38)

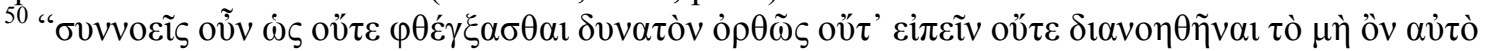

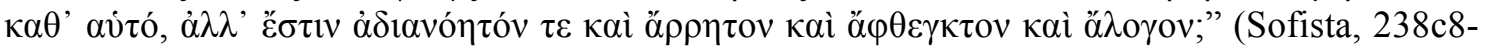
11)
} 
No caso do Sofista de Platão, a problemática que fez e faz tal texto célebre entre os estudiosos começa pela perplexidade a respeito de uma palavra. O termo "simulacro" ( $(\alpha ́ v \tau \alpha \sigma \mu \alpha$, em 236b7), segundo o diálogo, carregaria um problema em si mesmo: algo que imita e aparece sem copiar pode ser dito como algo que é sem ser, ou seja, algo que é e, ao mesmo tempo, não é. Podemos ver também que, já na enunciação da aporia, o termo $\varphi \alpha ́ v \tau \alpha \sigma \mu \alpha$, próprio de um vocabulário imagético, é associado ao âmbito discursivo e à falsidade ${ }^{51}$. Desta maneira, este simples termo poderá ser explicitado de pelo menos duas maneiras: aquilo que imita e aparece, mas, que por não ser semelhante ao modelo, não copia; ou, por outro lado, dizer algo, mas que não seja o verdadeiro, neste último caso estaria o problema de dizer e pensar o falso. Apesar das diversas maneiras pelas quais o problema pode ser identificado, pode-se ver que o problema é sempre relativo a um referencial externo ou a um modelo que se pretenderia tomar como base, mas não é devidamente legítimo na realização do procedimento. Tal é o modo como Platão formula a primeira aporia, chamada aporia do falso ou aporia do não ser:

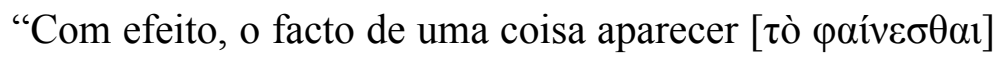

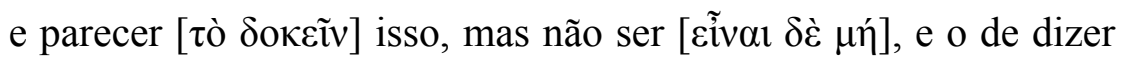

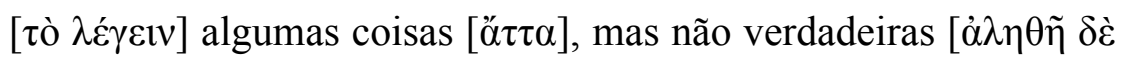
$\mu$ '́], tudo isso está cheio de dificuldades [ảjopías] o tempo todo tanto no passado, quanto agora. Pois, como se pode falando dizer

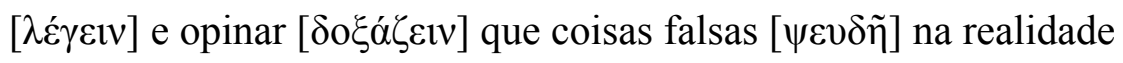

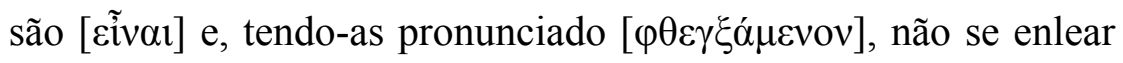

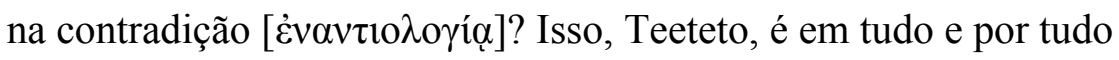
difícil." ${ }^{, 52}$ (Sofista, 236e1-237a1)

Como seria possível dizer algo (ő $\tau \tau \alpha)$, mas que não seja verdadeiro? A referência a algo já não implicaria um discurso verdadeiro? É necessário dizer que qualquer imagem

\footnotetext{
${ }^{51}$ Em 240d1-4, Platão faz a analogia entre o simulacro ( $\left.\varphi \alpha ́ v \tau \alpha \sigma \mu \alpha\right)$ e opinar falsidades ( $\psi \varepsilon v \delta \tilde{\eta}$

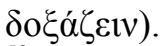

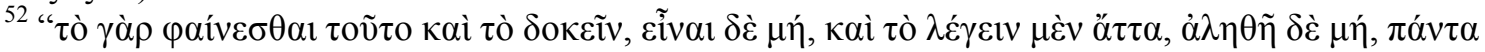

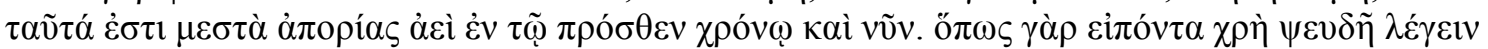

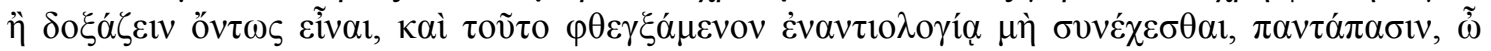

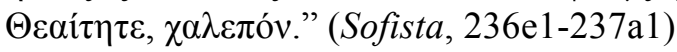


já seria um algo, e também é fato que, ao dizer qualquer coisa, já nos referiríamos a algum tipo de coisa existente. Como premissa implícita no trecho citado acima, necessária para a compreensão do problema e dos rumos que o diálogo tomará, temos a vinculação do verdadeiro ao que é e do falso ao que não é. Portanto, para Platão, a possibilidade de solução da aporia deverá nos levar a uma generalização nestes termos ontológicos: o não ser, de algum modo, deverá ser. A generalização, em termos de ser e não ser, seria necessária para a existência do falso, isto é, uma condição ontológica geral para que seja possível falsificar. No entanto, tal generalização terá de ajustar as contas com algo determinado: para entendermos a aporia do que não é ( $\mu$ ஸ̀ őv), será necessário a passagem pelo algo $(\tau \imath)$.

O contrassenso que apareceu no termo $\varphi \alpha ́ v \tau \alpha \sigma \mu \alpha$ (simulacro) pode ser visto na própria expressão "não ser" ( $\mu$ ஸ̀ őv). Se uma coisa ( $\tau$ ) é algo que sempre está vinculado

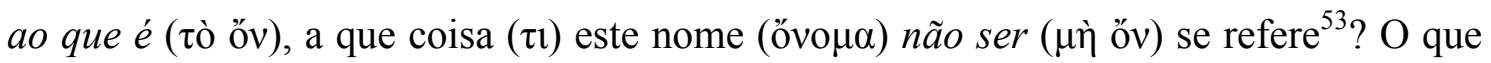
está em questão aqui é a relação, que aparentemente é necessária, entre o nome e a coisa (ővo $\mu \alpha / \tau \imath$ ), bem como uma indistinção entre o que é e um algo qualquer ( $\tau$ ò őv/ $/)^{54}$. Segundo Aubenque (AUBENQUE, 1991, p. 373), dois argumentos são utilizados pelo Estrangeiro para recusar a distinção entre uma coisa e aquilo que é:

(i) Um $\tau$ não existe por si mesmo, pois é uma determinação do ser (237d14).

(ii) Um $\tau$ l configura sempre uma unidade (237d9-10).

Como corolário de (ii) teríamos que: não dizer um $\tau$ significa dizer nem um $(\mu \eta \delta \varepsilon ́ v)$, ou seja, pela ambiguidade do termo $\mu \eta \delta \dot{\varepsilon ́ v}$, seria dizer nada (237e1-2).

\footnotetext{
${ }^{53}$ Sofista, 237b10-c4.

54 "La lecture attentive du texte de Platon montre que l'incohérence est due uniquement à l'assimilation platonicienne du 'quelque chose' et de l' 'étant'."(AUBENQUE, 1991, p. 378). Temos concordância com Aubenque e o seguimos no que diz respeito a sua formulação para a problemática do diálogo Sofista, mas, ao inverso da leitura do comentador francês, acreditamos que ao final do diálogo $\tau$ e $\tau$ ò őv estarão devidamente distinguidos. Esperamos que até o final de nossa dissertação fique claro que não será necessário esperar os estoicos, como acredita Aubenque (AUBENQUE, 1991, p. 379ss), para que tal distinção seja realizada.
} 
Tal problemática do não ser exposta no Sofista parece ser bem próxima de uma tese costumeiramente atribuída a Antístenes ${ }^{55}$ : não seria possível dizer o falso nem estabelecer controvérsia ( $\alpha v \tau \imath \lambda \varepsilon ́ \gamma \varepsilon \imath v)$. É provável que o discurso de Antístenes estivesse contaminado pelas já citadas teses sofísticas de Górgias ${ }^{56}$, de quem, segundo Diógenes Laércio, ele teria sido discípulo ${ }^{57}$. Temos pelo menos dois importantes testemunhos sobre a questão. O primeiro nos é oferecido por Aristóteles:

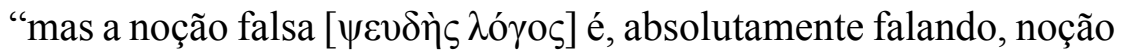
de nada [ov̉ $\theta \varepsilon v o ́ s]$. Por isso Antístenes considerava, de maneira simplista, que de qualquer coisa só se podia afirmar sua própria

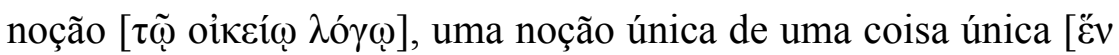
$\left.\dot{\varepsilon} \varphi \varphi^{\prime} \dot{\varepsilon} \vee \varsigma_{\zeta}\right] ;$ do que deduziu que não é possível a contradição

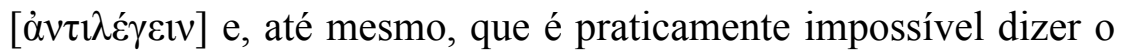

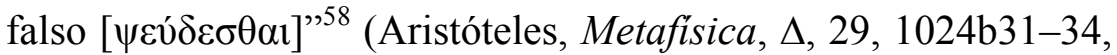
tradução de Marcelo Perine; ed. Prince 152 A; ed. Decleva Caizzi 47 A)

O segundo por Proclo:

“Antístenes disse que não se deve estabelecer controvérsia. Uma vez que, diz, todo discurso diz a verdade [ $\dot{\alpha} \lambda \eta \theta \varepsilon v ́ \varepsilon 1]$ : pois quem

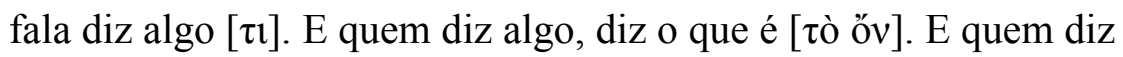

\footnotetext{
${ }^{55}$ Para os fragmentos e testemunhos de Antístenes, utilizamos o livro de Susan Prince (PRINCE, 2015).

${ }^{56}$ Acreditamos que tanto Górgias quanto Antístenes estabelecem um abismo entre ser e não ser dos eleáticos, este abismo faria com que a distinção entre o verdadeiro e o falso perdesse completamente o sentido. No entanto, as teses de Górgias e de Antístenes podem ser opostas segundo o critério da comunicabilidade: o discurso de Antístenes comunica sempre o que é; enquanto o de Górgias não tem função comunicativa (SOUZA, 2009, p.47.)

${ }^{57}$ DIÓGENES LAÉRCIO, VI 1; ed. Prince 11 A; ed. Decleva Caizzi 125.

${ }^{58}$ Tradução de Marcelo Perine a partir da tradução italiana de Giovanni Reale (Aristóteles,

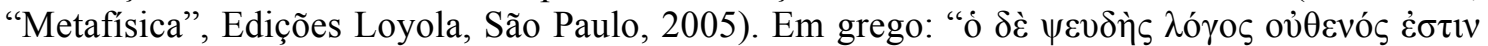

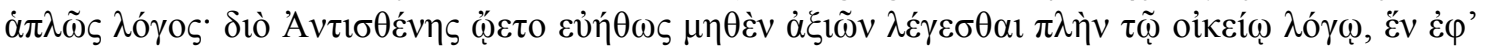

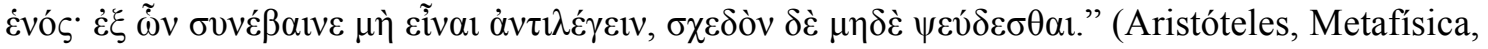
$\Delta, 29,1024 \mathrm{~b} 31-34)$
} 
o que é, diz a verdade [à่ $\eta \theta \varepsilon v ́ \varepsilon 1] .{ }^{, 59}$ (Proclo, comentário a 285b25 do Crátilo de Platão; ed. Prince 155; Decleva Caizzi 49. Tradução nossa)

O ponto de Antístenes é quanto à ligação necessária entre o discurso e a coisa, mas tomados um a um ("̌v $\left.\dot{\varepsilon} \varphi^{\prime} \dot{\varepsilon} \vee o ́ \varsigma\right)$. Este parece também ser o problema da aporia do falso, tal como exposta por Platão no Sofista. A dificuldade seria a seguinte: o discurso sempre se refere a algo $(\tau \imath)$, e para ser uma coisa $(\tau \imath)$, deve-se pressupor algo existente ( $\tau$ ò őv) nessa coisa, mas, por outro lado, o discurso falso é aquele que se refere a nada

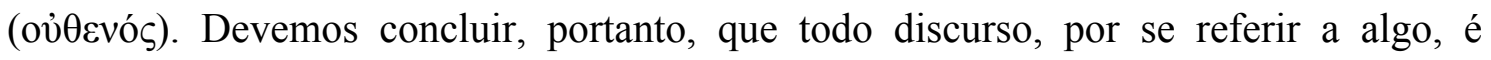
verdadeiro e que não é possível proferir um discurso falso. A única forma de erro que é possível neste contexto é tomar uma coisa por outra, dizer outra coisa que a que é, tomar Teeteto por Teodoro, o 11 pelo 12, uma pomba silvestre ao invés de uma doméstica (Teeteto, 199b). Confundir duas coisas que são é dizer outra coisa. Nos termos de Platão, a confusão entre duas coisas diferentes, causa do erro, poderia ser chamada então "outra

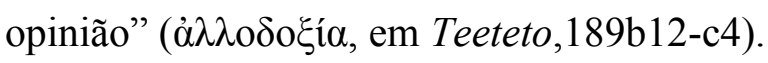

Poderíamos dizer que, para Antístenes, cada discurso deve estabelecer uma relação funcional com a coisa que por ele é dita e, se o discurso não diz nada, não é discurso. A referencialidade é, portanto, condição para o discurso. No entanto, outra coisa é pressuposta neste argumento de Antístenes: tanto o discurso quanto a coisa são

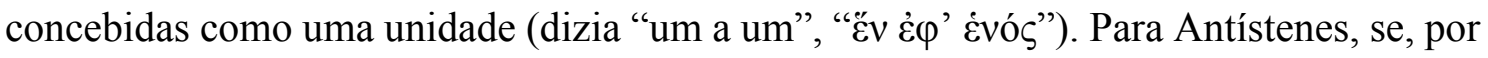

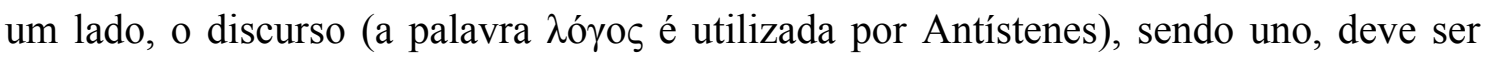
sempre tomado como um nome (daí a palavra ővo $\mu \alpha$ utilizada por Platão), por outro, aquilo que é ( $\tau$ ò óv) e a coisa ( $\tau \imath)$ são vistos como o mesmo.

A unidade entre $\tau \imath$ e $\tau$ ò ő $v$ pode ser explicada a partir da equivalência gerada por duas implicações. A primeira é vista de maneira clara no testemunho de Proclo: temos ali a implicação "se $\tau$, então $\tau$ ò oov". Soma-se a isso o fato de, no comentário às Categorias de Aristóteles, Simplício (fragmento 149 B-1 segundo Susan Prince, 50 A para Decleva Caizzi) relatar que Antístenes teria dito contra Platão: "Vejo cavalo, mas não vejo

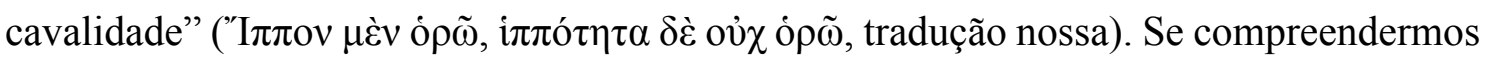

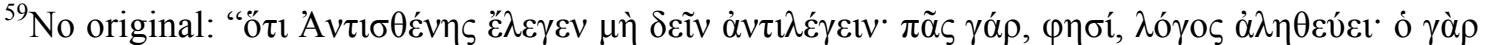

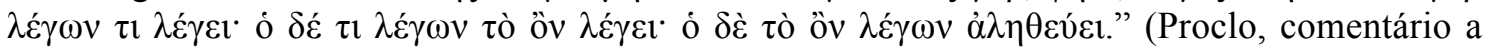
285b2-5 do Crátilo de Platão)
} 
a negação do universal (a cavalidade, no caso) como restrição do ser ( que todo ser é um particular (um $\tau$, no caso, um cavalo) e consolidaremos, portanto, a outra implicação que é necessária para a equivalência entre $\tau$ e $\tau$ ò őv: "se $\tau$ ò őv, então $\tau \imath$.

No Sofista, Platão atacará o pressuposto de Antístenes que enuncia a unidade (๕̌v), tanto aquela que se apresenta no discurso (compreendido como nomeação) quanto a unidade entre a coisa $(\tau \imath)$ e aquilo que é ( $\tau$ ò őv), esta última apresentada na passagem do $\tau$ para $\tau$ ò őv tal como testemunhada por Proclo. Este problema que pode ser identificado em Antístenes, o da unidade entre a coisa ( $\tau$ ) e o que é ( $\tau$ ò őv) bem como de sua vinculação com um nome (ővo $\mu \alpha$ ), é tratado pelo Estrangeiro em 244b9-d12:

"Hóspede de Eleia ${ }^{60}$ - Pois bem, que respondam a isto: 'vós dizeis que só um é’? 'Dizemos', responderão eles [o pronome "eles” se refere aos que dizem que o todo é um], pois não?

Teeteto - Sim.

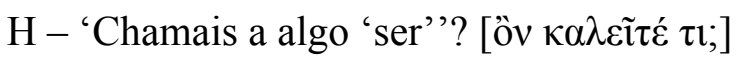

$\mathrm{T}-\mathrm{Sim}$.

$\mathrm{H}$ - 'De duas uma; como a 'um', servindo-se de dois nomes para o mesmo, ou como?'

$\mathrm{T}-\mathrm{E}$ aí, que resposta, Hóspede, haverá para eles depois disso?

$\mathrm{H}-\mathrm{E}$ evidente, Teeteto, que àquele que supõe essa hipótese em relação ao perguntado agora e em relação a outra coisa qualquer que seja, não é nada fácil responder.

$\mathrm{T}-\mathrm{Como}$ ?

$\mathrm{H}$ - O facto de concordar que são dois nomes, nada postulando além de um, é de algum modo ridículo.

T - Como não.

$\mathrm{H}-\mathrm{E}$ de todo aceitar de quem fala que há um certo nome [ővouá] que não tem explicação [ $\lambda$ ó $o v]$.

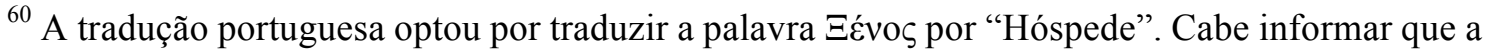
personagem a que nos referimos como "Estrangeiro" ou "Estrangeiro de Eleia" designa aquela mesma que é denominada "Hóspede" pela tradução da Editora Calouste Gulbenkian.
} 


\section{T - Porquê?}

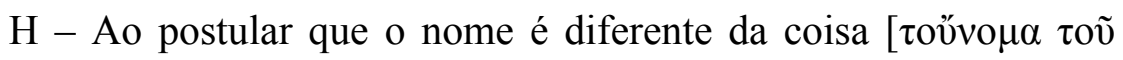

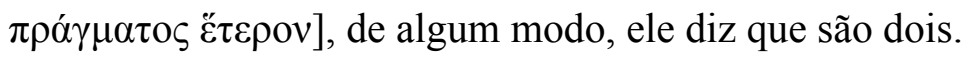

$\mathrm{T}-\mathrm{Sim}$.

H - E mais, se sustentar que o nome é o mesmo que a coisa, ou será obrigado dizer que é nome de nada [ $\mu \eta \delta \varepsilon v o ̀ \varsigma]$, ou, se disser que é

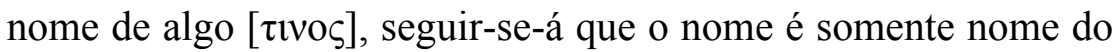

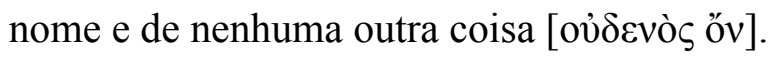

$\mathrm{T}-\dot{\mathrm{E}}$ assim.

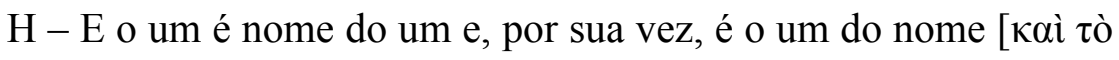

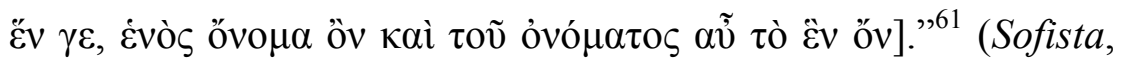
244b9-d12, tradução ligeiramente modificada por nós)

Esta última frase (244d11-12), que parece dar uma conclusão ao bloco, antes da inserção de um novo conceito ${ }^{62}$, tem grave divergência nas lições dos manuscritos. Dentre as edições do texto grego que conhecemos, para esta frase, certamente a versão de Burnet (edição na qual se baseou a tradução da editora Gulbenkian) é a menos fiel aos manuscritos. As edições de Diès e Robinson são mais próximas dos manuscritos

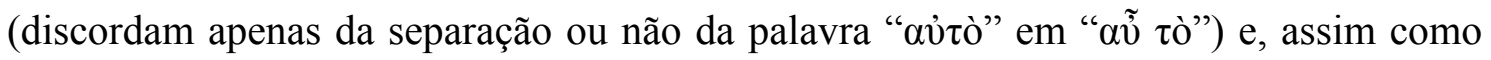

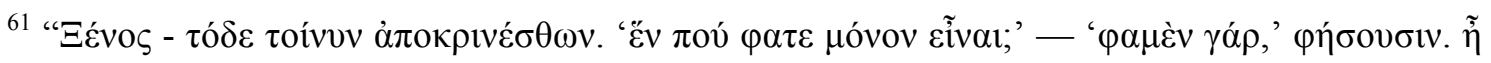

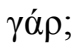

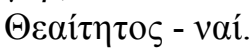

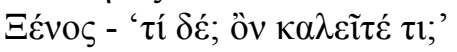

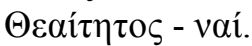

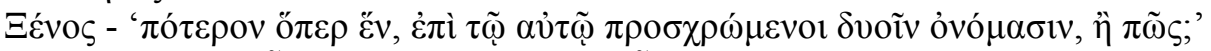

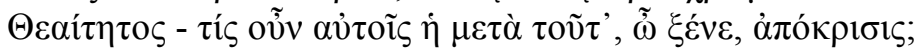

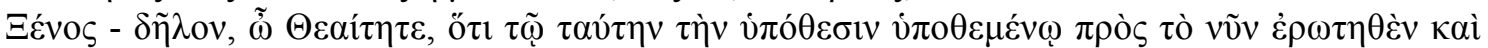

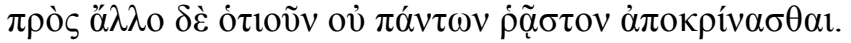

$\Theta \varepsilon \alpha i ́ \tau \eta \tau о \varsigma-\pi \tilde{\omega} \varsigma ;$

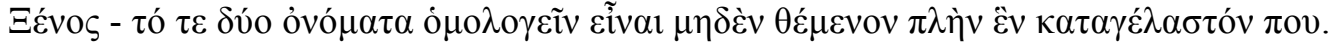

$\Theta \varepsilon \alpha i ́ \tau \eta \tau о \zeta-\pi \tilde{\omega} \varsigma \delta$ ở;

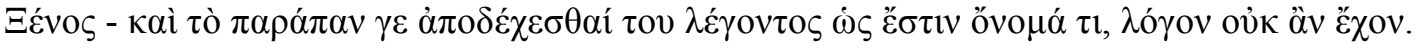

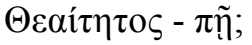

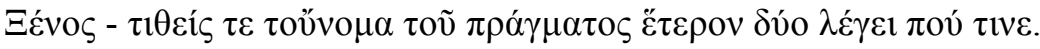

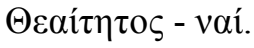

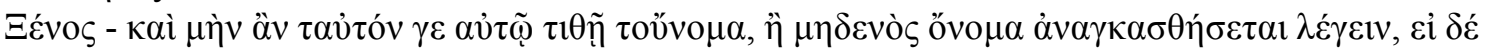

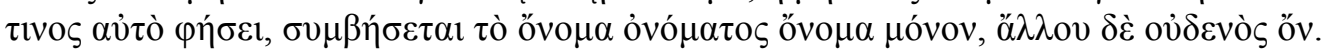

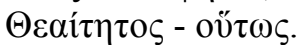

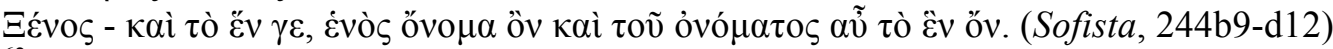

${ }^{62} \mathrm{O}$ de "todo" (öhov) em 244d14.
} 
Cordero (PLATON, 1993, p. 244, nota 211), seguem os manuscritos B, D e W'63. Tais alterações mudam significativamente o sentido da frase. Na versão de Diès poderíamos

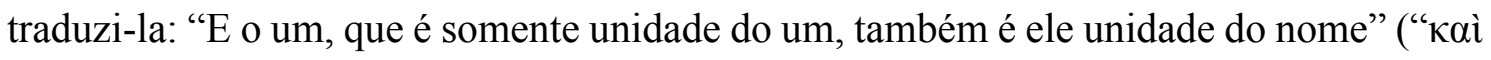

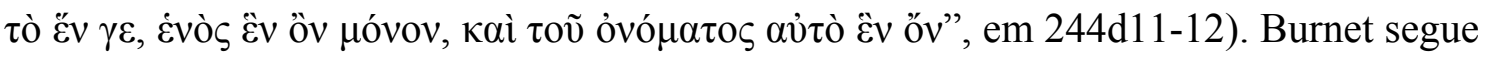
a intromissão de Apelt (este grafa “...غ่vò

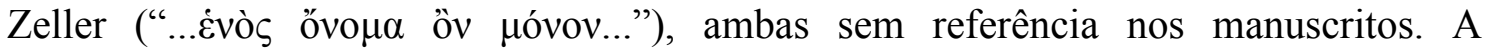
divergência entre os textos é filosoficamente relevante pois a passagem trata da unidade do um que é também unidade do nome (“o um é um” e "o nome é um”, com o ser compreendido em sentido existencial), e não do nome da unidade e da unidade do nome (como se pretendesse uma equivalência entre "unidade" e "nome"), como parece ter compreendido a edição de Burnet. A questão filosófica é que o um é um e o nome é um, ou seja, o um abarca certa multiplicidade, pois é um e é nome. Assim como, mais adiante, o ser é ser e também o ser é não ser, ou seja, é o mesmo e também o outro, aqui, aparentemente, identifica-se que em qualquer unidade há certo espaço para a multiplicidade: é um e é outro e, se é outro, de algum modo, é múltiplo ${ }^{64}$.

De qualquer modo, o problema aqui é, com efeito, bem semelhante àquele que identificamos nos testemunhos sobre Antístenes ${ }^{65}$ : parece estar assegurada a relação paralela entre discurso e ser, o problema se dará na unidade entre algo $(\tau \imath)$ e o que é ( ò őv). Na versão de Platão teremos: como é possível atribuir dois nomes ( $\tau$ e $\tau$ ò ǒv, na passagem acima) a algo que é um? Como podemos considerar a unidade ao mesmo tempo algo e ser? Como podemos atribuir dois nomes ( $\tau \iota$ e őv) a um (๕̂v)? Deverá ficar garantida a correlação entre discurso e ser, pois, caso estejam em mesmo nível, não poderá haver referência discursiva a algo e nossa linguagem, portanto, não dirá nada. Será esta problemática que nos conduzirá às famosas oposições entre doutrinas tal como foram expostas no Sofista (a partir de 242b): se iniciando pela doutrina do múltiplo versus a

\footnotetext{
${ }^{63}$ Os manuscritos T e Y suprimem o segundo $\tilde{v} v$ da frase, o que não altera o sentido da frase grafada em B, D e W.

${ }^{64}$ Tal passagem nos remete ao diálogo Parmênides (137c-d)

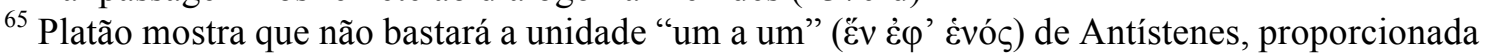
pela nomeação de algum ser. Será necessário mostrar que, se quisermos demarcar a oposição entre verdade e falsidade, a unidade deve abarcar certo tipo de multiplicidade. Afinal de contas, parece ser um pressuposto da própria leitura de Antístenes aceitar que a unidade tautologicamente é unidade, mas, ao mesmo tempo, também o nome é uma unidade. Lida desta forma, essa passagem parece conter um embrião daquilo que será exposto na segunda aporia (Sofista, 251ac).
} 
doutrina do um, passando pela batalha de gigantes entre os partidários do corpo versus os das formas, até finalizar tratando do movimento em oposição ao repouso.

Podemos ver, portanto, que não é por acaso que a continuação da exposição do problema do falso, no Sofista, a partir de 238a, se direcionará para a questão da unidade (Èv) e da multiplicidade $(\pi \lambda \tilde{\eta} \theta 0 \varsigma)$ : como vimos, a questão é identificada pelo problema da unidade ontológica entre a coisa $(\tau \imath)$ e o que é ( $\tau$ ò őv), bem como pela correlata unidade do discurso ( $\lambda$ ó ${ }^{\circ} \varsigma$ ) compreendido como nome (ővo $\left.\mu \alpha\right)$. Para Platão, não poderíamos

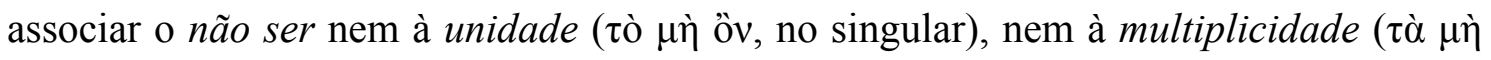
ővta, no plural), posto que tanto a unidade quanto a multiplicidade são (238b). No entanto, a aporia do não ser se potencializa ainda mais quando o Estrangeiro percebe que quando conclui que o não ser é “impensável, indizível, impronunciável e inexplicável”

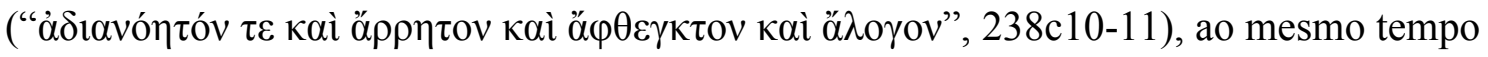
em que nega a unidade e a multiplicidade do não ser, trata-o como um (unidade expressa

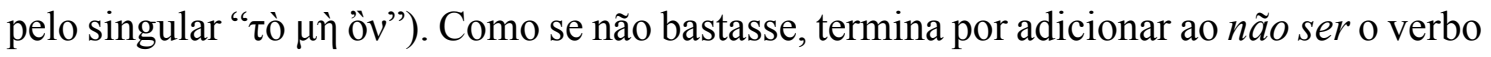

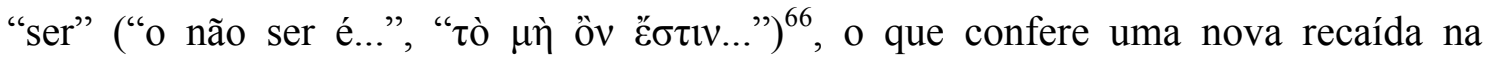
contradição. O Estrangeiro percebe, portanto, que caiu na armadilha do sofista: armadilha que obriga o filósofo, na ânsia de capturar o sofista, a entrar em contradição com seu próprio discurso e a concordar que o que não é de alguma forma é (240c6). Teeteto diz:

"Há o risco de nos termos emaranhado numa certa

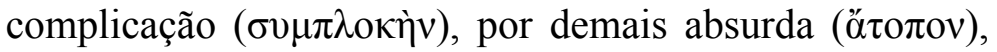

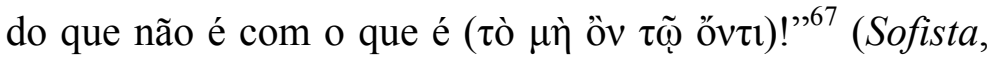
240c2-3)

A esta altura do diálogo, o entrelaçamento entre ser e não ser é visto como absurdo

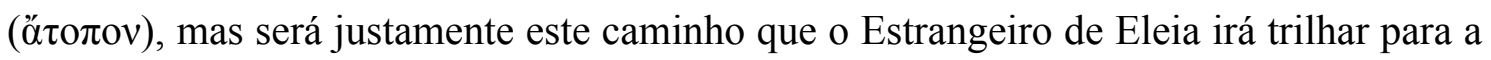
resolução da problemática trazida pelas duas aporias: de problema, o entrelaçamento

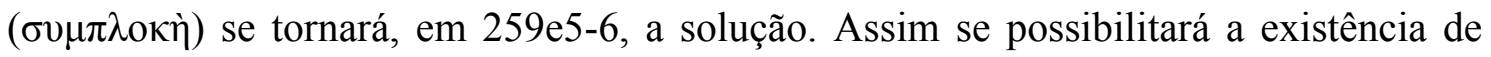

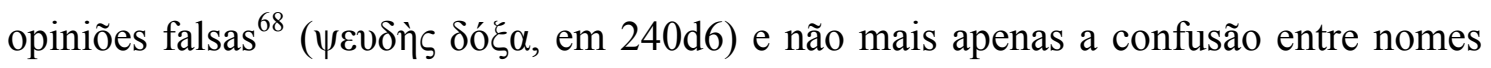

\footnotetext{
${ }^{66}$ Deste modo, claramente estaríamos indo contra as recomendações de Parmênides, que dizia para nunca trilhar o caminho que força a mistura entre ser e não ser (Sofista, 237a8-9 e 258d2-3).

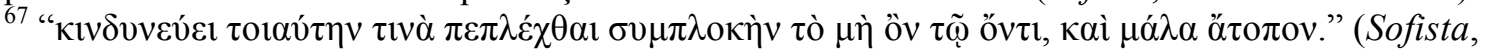
240c2-3)

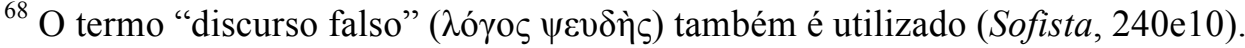


( $\left.\dot{\alpha} \lambda \lambda \circ \delta \circ \xi^{i} \alpha\right)$, aparentemente defendida por Antístenes e apontada por Platão no Teeteto. Com base no que foi dito, poderemos dizer, portanto, e a partir de agora com propriedade, que a problemática tratada no Sofista é lógica-ontológica: aparece, na primeira aporia, com a vinculação do não ser ao discurso falso.

A relação entre lógica e ontologia se desdobrará de modo paralelo na segunda aporia (aporia do ser), a dificuldade será agora a de associar o ser a um discurso verdadeiro que não tenha de ser necessariamente tautológico. Se é a partir de 242 c que o Estrangeiro de Eleia passa conduzir o problema do não ser em direção ao ser, é só em 251 a5 que a segunda aporia, a aporia do ser, é manifestada. E a aporia, que não permitia que nenhum lado dos pares doutrinários expostos (uno/múltiplo, formas/corpos, movimento/repouso) desse conta da explicação do que não é ( $\mu$ ஸ̀ ôv), agora passa a mostrar que qualquer uma dessas doutrinas se mostra também inócua para a explicação

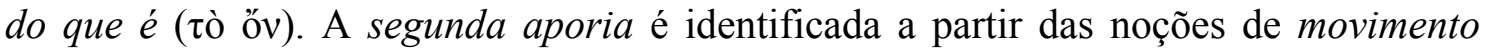

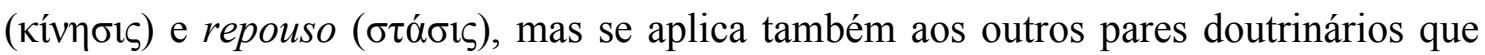
foram anteriormente expostos ${ }^{69}$ :

"Teeteto: Corremos o risco de entrever o ser verdadeiramente como um terceiro, quando afirmamos que repouso e movimento são.

Hóspede de Eleia: Portanto, o ser não é a combinação de movimento e repouso, mas, ao contrário, algo diferente desses.

T: Parece

H: Portanto, segundo a sua natureza, o ser não está parado nem se $\underline{\text { move. }}$

T: É quase isso.

$\mathrm{H}$ : Para onde ainda precisa dirigir o raciocínio aquele que quiser chegar a ter seguro em si algo claro a respeito do ser?

T: Pois, para onde?

H: Creio que ainda não é fácil chegar a nenhum lugar. Pois, se algo não se move, como não está parado? Ou, o que de nenhum modo está parado por sua vez não se move? Ora, o ser manifesta-se a nós agora alheio a uma e outra dessas alternativas. É isso possível?

${ }^{69}$ É possível interpretar também que Platão parece pretender resolver todas essas querelas doutrinárias num só golpe, com a resolução das duas aporias. 
T: É mais impossível que tudo." ${ }^{70}$ (250c1-250d4, os grifos são nossos e a tradução foi levemente modificada)

O trecho, que de certa forma retoma 243d6-e6 (sobre aqueles que afirmam que tudo é dois: quente e frio), agora introduz a noção de oposição contraditória

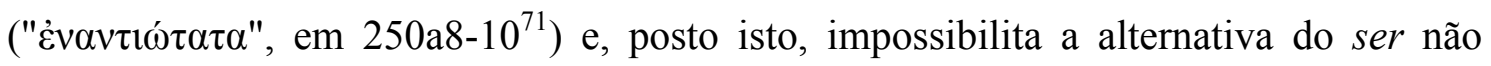
pertencer nem ao repouso, nem ao movimento (pois se não fosse movimento seria necessariamente repouso e se não fosse repouso seria necessariamente movimento). Assim, a princípio, não existe a possibilidade do ser existir como um terceiro independente dos contrários. A impossibilidade de tal alternativa é postulada neste momento do texto platônico e, ao nosso ver, se mostra muito semelhante ao que foi chamado de terceiro excluído ${ }^{72}$. No entanto, mais a frente, pretendemos notar como Platão resolverá isso a partir da instituição de duas noções que não sejam mais opostas contraditoriamente, mas contrapostas dialeticamente (oposição que deixará de ser

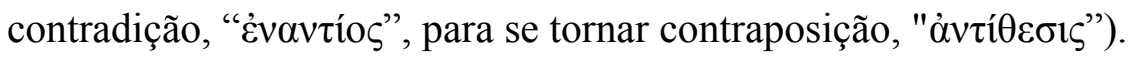

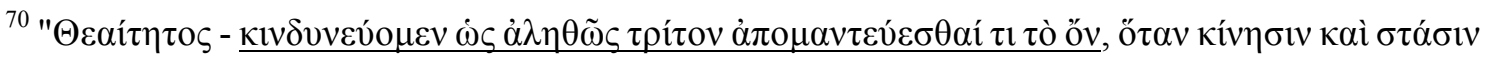
عĩvaı $\lambda \dot{\varepsilon} \gamma \omega \mu \varepsilon v$.

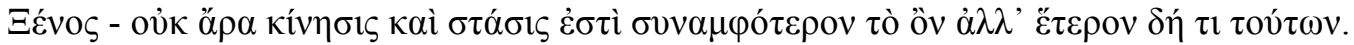

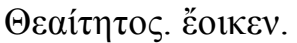

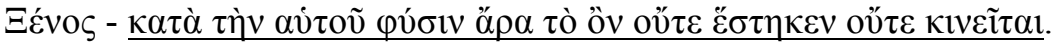

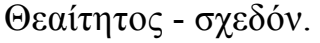

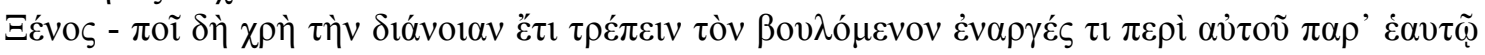
$\beta \varepsilon \beta \alpha 1 \omega ́ \sigma \alpha \sigma \theta \alpha 1$

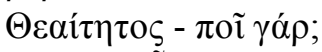

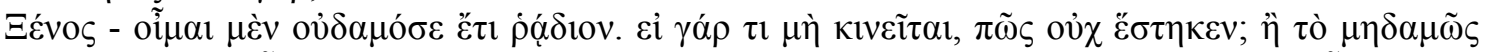

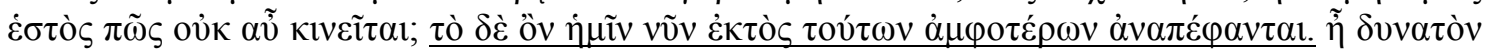

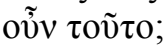

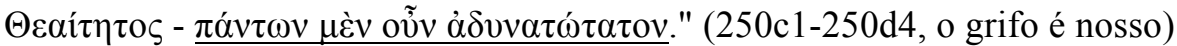

71 "Hóspede de Eleia: Pudesse ser! Acaso não afirmas que movimento e repouso são o mais contrários um ao outro?

Teeteto: Pois, como não?"

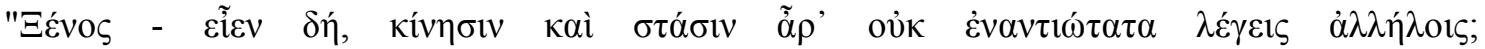

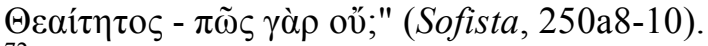

${ }^{72}$ Mesmo que não seja de nenhuma valia, pois a questão não parece ser puramente proposicional, vale notar que o princípio de não contradição em conjunção com o princípio do terceiro excluído implica o princípio de bivalência: pois, para qualquer proposição $P$, não é possível "P e não $P$ " (não contradição), e também não podemos ter "nem $\mathrm{P}$, nem não $\mathrm{P}$ " (terceiro excluído), logo, resta apenas $\mathrm{P}$ ou não $\mathrm{P}$ (bivalência). A comparação se torna ainda mais interessante pelo fato do estabelecimento da bivalência proposicional parecer ser o grande objetivo do "Sofista". Apesar do interesse ser grande, não operaremos esta leitura por acharmos esta aplicação da lógica formal contemporânea aos textos antigos por demais anacrônica. Tal dificuldade no uso do instrumental formal contemporâneo se torna ainda maior quando se trata de um pensamento pré-aristotélico.
} 
Conforme indicado em 250e6-251a1 ${ }^{73}$, a solução proposta pelo estrangeiro agirá sobre as duas aporias e solucionará as duas dificuldades em um só lance. As aporias ontológicas são identificadas por meio da estrutura entre as orações que as enunciam, ou seja por sua forma lógica. Primeira aporia, a do não ser e do falso: o não ser é (P e nãoP). Segunda aporia, do ser e do verdadeiro: posto que P não é o mesmo que o ser, o ser nem é P, nem é não-P. Esta última aporia é evidenciada pelo "nem...nem..." que

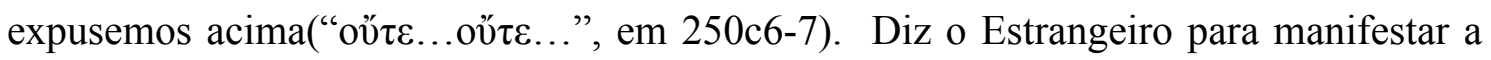
segunda aporia:

"Digamos então como, de cada vez, chamamos a mesma coisa com muitos nomes",74 (Sofista, 251a5-6)

Podemos considerar, então, que "o ser não estar parado nem se mover”, "o ser não é nem um nem múltiplo", e "a mesma coisa é chamada de muitos nomes" sejam manifestações ou diferentes pontos de vista sobre um mesmo e determinado problema. Ao decorrer do diálogo, a existência desse discurso que mistura os opostos deverá ser justificada e fundamentada, isto é, deverá ser garantida uma legitimidade para o seu uso.

O problema do um e do múltiplo, que já havia sido prenunciado em $244 \mathrm{~d}$, volta à tona e se transfigura, na passagem citada acima, no problema da incompatibilidade do

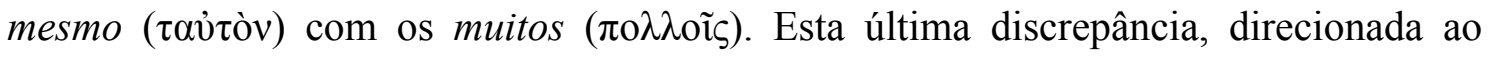
discurso, será identificada com o problema da impossibilidade da definição não tautológica de algo, ou, para dizer de outro modo, com a inviabilidade daquilo que chamaríamos hoje de predicação (isto é, sendo $\mathrm{X}$ diferente de $\mathrm{Y}$, como atribuir um Y a um X?): aparentemente, para garantir o uso da predicação e de uma definição que tenha relevância, teríamos que assumir que a uma mesma coisa possa ser acrescentada muitas outras. Platão explicita a aporia da seguinte maneira:

\footnotetext{
73 "Uma vez que, em pé de igualdade o ser e o não ser fazem parte da aporia, surge agora uma esperança de que, se um dos dois aparecer mais embaçado ou mais claro, que o outro deles assim

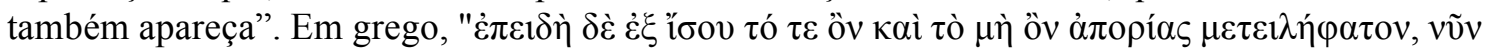

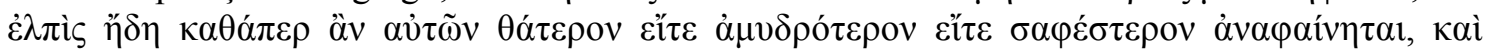

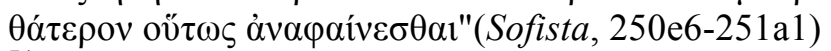

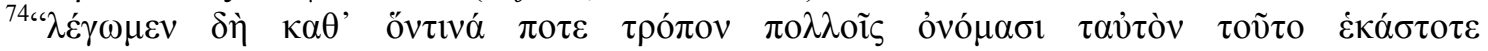

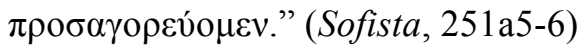


"Falamos de homem, aplicando-lhe variadas denominações, atribuindo-lhe cores e figuras, grandezas, vícios, virtudes; e, em todos estes e milhares de outros casos, não só dizemos o próprio homem, mas também que é bom e outras coisas sem fim. E também outras coisas ainda, cada uma das quais, de acordo com o mesmo discurso, supomos serem uma $[\tilde{\varepsilon} v]$ e dizemos muitas $[\pi 0 \lambda \lambda \grave{\alpha}]$ com

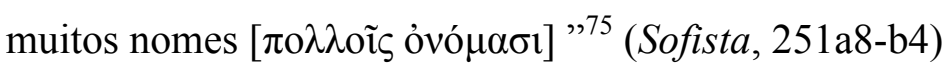

E continua:

"De onde, creio, preparámos um banquete para os mais jovens e, de entre os velhos, os tardios a aprender; a qualquer um está ao

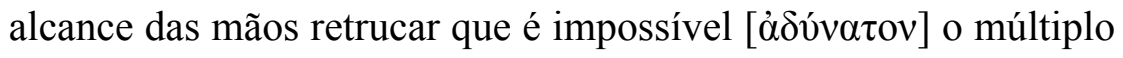

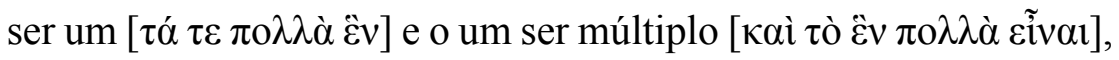
por isso alegram-se não deixando chamar ao homem bom, mas ao bom bom e ao homem homem."76 (Sofista, 251b6-c2)

Deste modo, a dificuldade em justificar a atribuição de um predicado a um sujeito mostra-se completamente decorrente da problemática que dizia respeito ao um e, consequentemente, ao seu par oposto, o múltiplo. Assim como a primeira, a segunda aporia é também bem parecida com uma tese atribuída a Antístenes: a da impossibilidade de definição. Tenhamos em mente que a importância da noção de definição (marcada pela

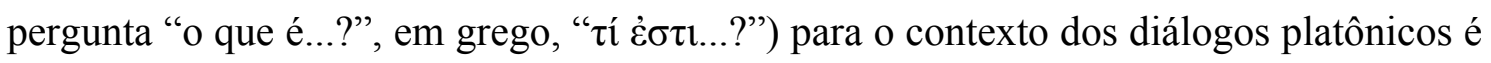
central, principalmente nos diálogos da juventude, ditos "socráticos". Relata-nos Aristóteles a respeito de tal tese de Antístenes:

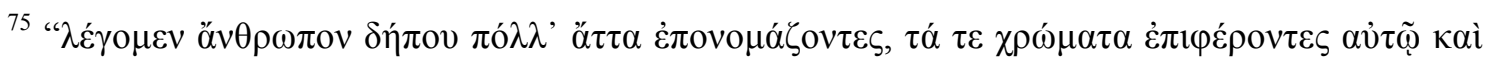

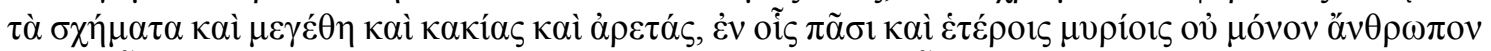

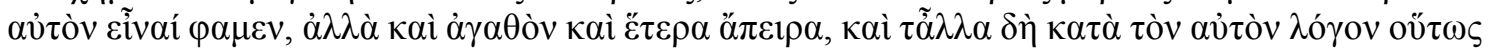

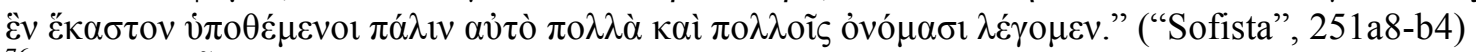

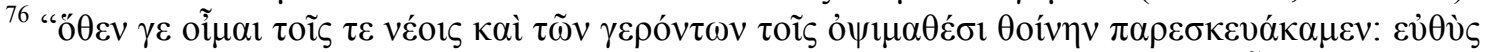

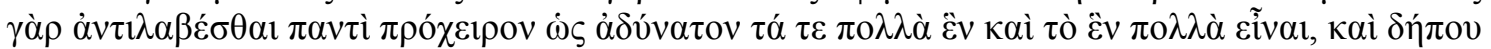

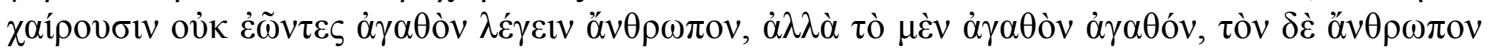

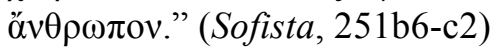


"Por conseguinte, tem algum acerto o impasse com o qual os Antistênicos e outros assim desprovidos de formação se

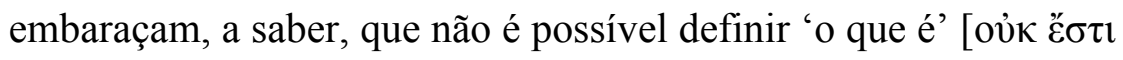

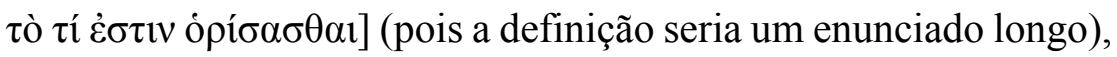
mas que seria possível, sim, ensinar de que realidade é, mas não $o$ que é (por exemplo, que a prata é tal como o estanho). Por conseguinte, haveria uma essência da qual seria possível haver definição e enunciado - isto é, a composta, seja ela sensível ou inteligível -; por outro lado, dos itens primeiros de que ela se constitui, mas não seria possível haver definição, visto que o

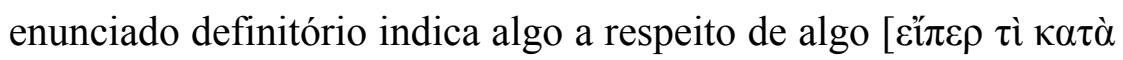

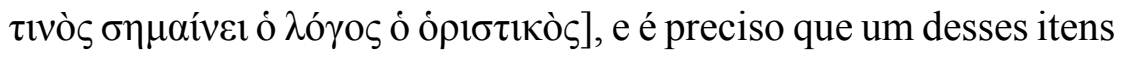
seja como matéria, e o outro, como forma." (Aristóteles, Metafísica, VIII, 1043b23-32, tradução de Lucas Angioni ${ }^{77}$; ed. Prince 150 A; Decleva Caizzi 44 A)

Ou seja, definir algo é, de algum modo, articular diferentes nomes, e isso pressuporia tratar de uma unidade em associação com uma multiplicidade. Outra passagem exposta por Aristóteles também pode ser comparada ao trecho do Sofista. Uma passagem aristotélica que também identifica o problema do ser com relação ao um e ao múltiplo:

“Até mesmo os últimos dos antigos se perturbaram cuidando para que a mesma coisa não se lhes tornasse ao mesmo tempo uma e

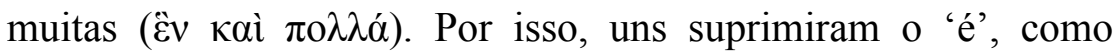
Licofrão, ao passo que outros requintaram o modo de falar: não 'o homem é branco', mas 'branquejou-se', nem 'é caminhante', mas 'caminha', a fim de que não fizessem um ser muitos, ao aplicar-lhe

\footnotetext{
${ }^{77}$ ARISTÓTELES, 2005, p. 117
} 
o 'é' - como se um e ente se dissessem de uma só maneira."78 (Aristóteles, Física I, 2 185b25-32, tradução de Lucas Angioni ${ }^{79}$ )

Isto é, como o problema do um e do múltiplo é tratado em termos relativos ao ser, muitos pensadores da antiguidade imaginaram que o problema estaria resolvido por um simples ocultamento do verbo "ser". No entanto, concluímos, pela interpretação da primeira aporia e de sua passagem à segunda, que, para Platão, pelo menos no Sofista, as dificuldades oriundas das oposições entre um/múltiplo, todo/partes, forma/corpo, mesmo/outro e repouso/movimento são expressões de um mesmo problema ontológico fundamental: o do abismo ontológico entre ser e não ser. Identificada a origem comum de todas essas querelas, ou seja, aquilo que para Platão seria a raiz das várias discordâncias entre doutrinas, a resolução da questão relativa aos diversos pares de conceitos opostos deverá ser realizada a partir de um único e certeiro golpe ${ }^{80}$.

De certa forma aqueles que suprimiram o verbo "ser" de suas frases fizeram um diagnóstico correto, mas erraram na profilaxia, isto é, não enfrentaram o problema, ocultando-o de maneira apenas paliativa. Fato é que tais problemas só poderão ser resolvidos ao voltarmos os olhos para as relações entre os elementos que constituem os enunciados, isto é, teremos que garantir que o discurso seja constituído de partes, que seja um discurso articulado, que o um seja múltiplo e que o ser, de algum modo, não seja. Em termos ontológicos, para resolver a aporia devemos instituir uma comunidade entre os entes (ou, como queira, entre as formas) e um modo de fazê-los participar um do outro.

III

No entanto, muitas vezes os platonistas e estudiosos do diálogo Sofista não nos informaram que estas duas aporias expostas acima decorrem da tentativa de justificar dois

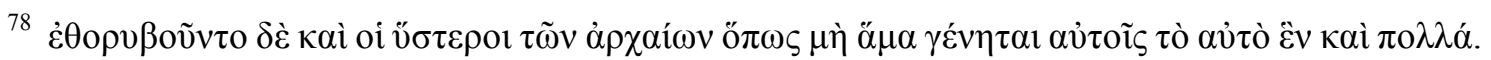

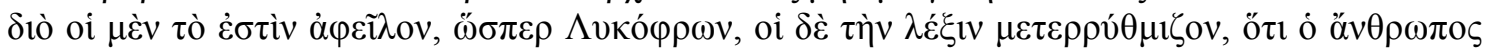

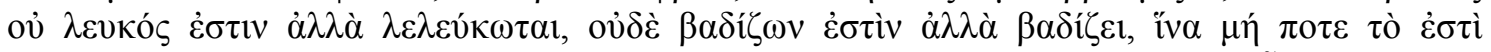

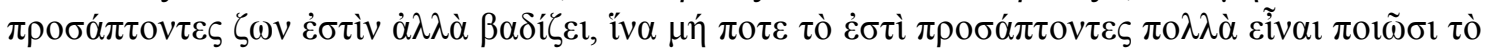

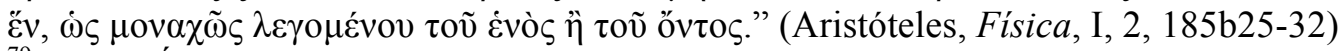

${ }^{79}$ ARISTÓTELES, 2009.

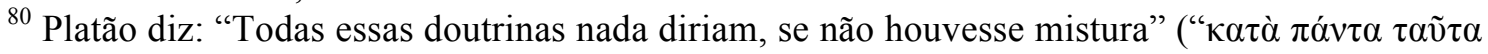

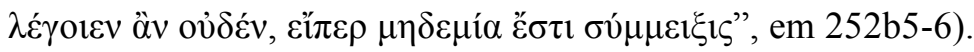


termos de uma das divisões operadas no diálogo ${ }^{81}$. Podemos recuar no texto platônico e identificar que toda essa discussão com o eleatismo tem origem em $235 \mathrm{c} 9-\mathrm{d} 2$, quando Platão, no interior da sétima e última definição de sofista, enuncia a divisão de duas formas da arte de imitar: a arte da cópia (

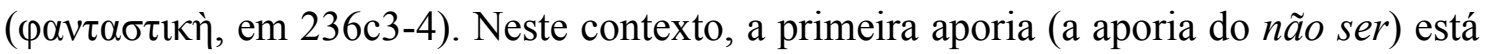
vinculada à justificação da existência de um simulacro ( $(\alpha ́ v \tau \alpha \sigma \mu \alpha)$, condição necessária

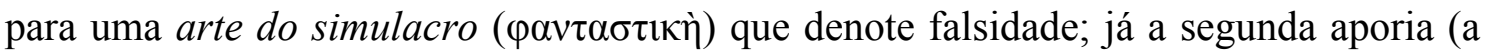
aporia do ser) se associa à tentativa de conferir as condições ontológicas para a existência

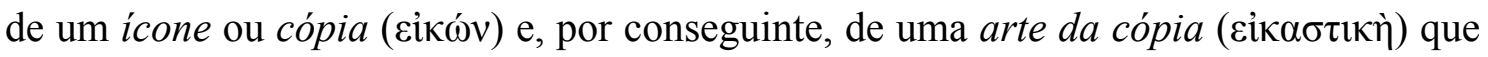
o tomaria como base, ou seja, garantiria a possibilidade de se conceber uma cópia fiel e verdadeira.

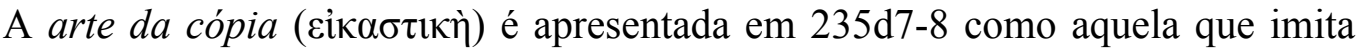

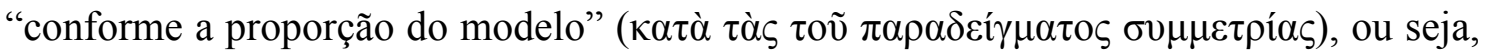
esta arte seguirá "das coisas belas a verdadeira proporção" ( $\tau \tilde{\omega} v \kappa \alpha \lambda \tilde{\omega} v \dot{\alpha} \lambda \eta \theta$ vvìv

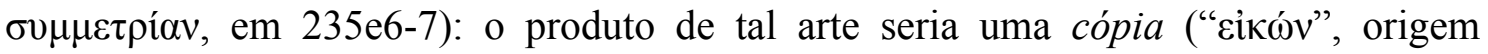
etimológica da palavra portuguesa “ícone”). Dirá Platão em 236a8-9: “não é justo, o que

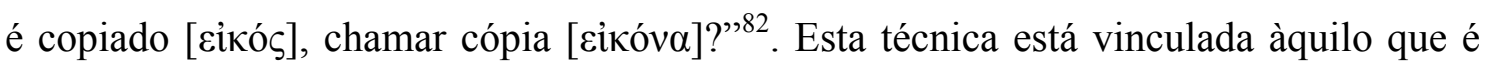
verdadeiro e, ao que parece, para garantir a possibilidade de tal arte, será necessário perseguir (a partir de 250e) a solução da aporia do verdadeiro ${ }^{83}$.

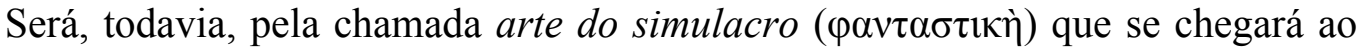
grande problema que tomará grande parte do diálogo. Deste modo, será a partir da incompreensão e perplexidade a respeito da possibilidade de uma arte do simulacro que se originará a primeira aporia, a aporia do falso. Em 236b7, o Estrangeiro explicita: a arte

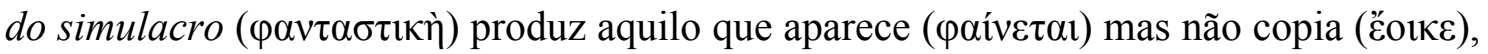
produz aquilo que chamaremos de simulacro $(\varphi \alpha ́ v \tau \alpha \sigma \mu \alpha)$. Assim, não demora a ser enunciada a aporia do falso:

\footnotetext{
${ }^{81}$ Sobre a falta de interesse dos comentadores com relação à ligação entre a última definição de sofista e a proposta ontológica do diálogo, ver DIXSAUT, 2000, p. 272.

82 Tradução nossa.

${ }^{83}$ A aporia do falso parece incontestavelmente decorrer da possibilidade de realização da arte do simulacro. Se considerarmos que a aporia do verdadeiro está relacionada à arte da cópia, compreenderemos por que a solução de uma aporia leva à solução da outra (em 250e-251a): tal relação se deve à compreensão do próprio método da divisão, no qual a conjunção das duas partes que são contrapostas numa determinada divisão necessariamente deve resultar numa unidade sintetizada a partir delas. Assim, solucionando uma das partes da divisão, posto que são a dupla divisão de um todo conhecido, se solucionaria, por exclusão, a outra parte também.
} 
“Com efeito, o facto de uma coisa aparecer e parecer isso, mas não ser, e o de dizer muitas coisas, mas não verdadeiras, tudo isso está cheio de dificuldades o tempo todo, tanto no passado, quanto agora. Pois, como se pode falando dizer ou opinar que coisas falsas na realidade são e, tendo-as pronunciado, não se enlear na contradição?" ${ }^{84}$ (Sofista, 236e1-5)

E o Estrangeiro ainda conclui:

"Essa declaração teve a ousadia de supor que o que não é é, pois de outra maneira a falsidade não viria a ser." ${ }^{85}$ (Sofista, 237a3-4)

Entretanto, para Platão, a dificuldade na distinção entre a arte da cópia e a arte do simulacro se deve ao fato de ambas serem espécies de um só gênero: resultam da

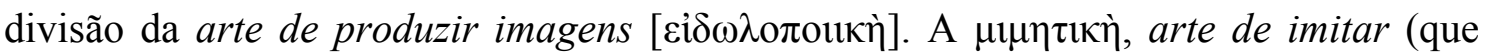
ocorre em 235d1 e 235c3), por sua vez, parece, neste contexto específico, ser sinônima de arte de produzir imagens ( $\varepsilon i \delta \omega \lambda$ o produzir imagens fazem referência, pelo menos aqui, à mesma prática e à mesma atividade:

"Fica então acordado dividir o mais rápido possível a arte de

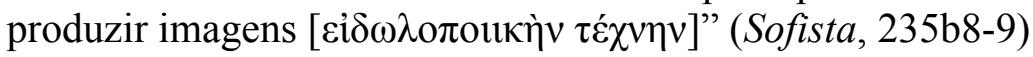

Paralelamente temos a identificação desta com a arte de imitar:

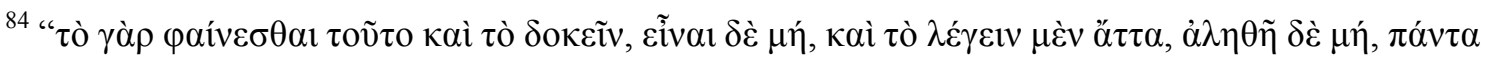

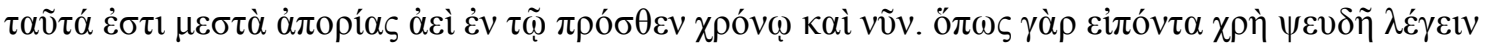

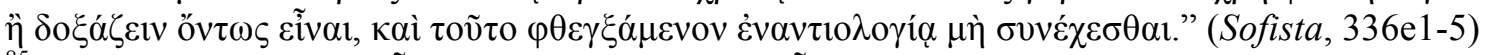

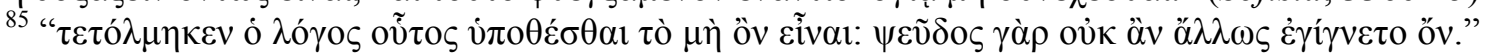
(Sofista, 237a3-4)

${ }^{86}$ Opinião também de Nestor-Luis Cordero: "Le mot $\varepsilon i \delta \omega \lambda$ i

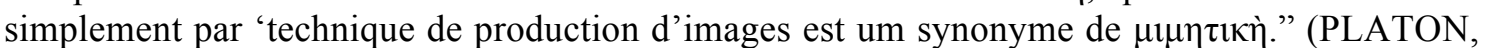

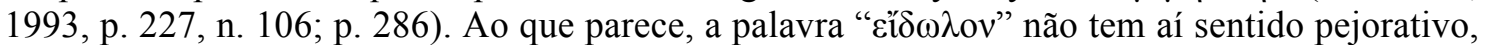
significa simplesmente "imagem" (como podemos bem ver no uso do termo $\varepsilon$ ‘ $\delta \omega \lambda$ ov em $239 \mathrm{~d}-$ 240b).
} 
"Segundo o modo de divisão proposto, eu mesmo agora acho que distingo duas formas da arte de imitar $[\mu 1 \mu \eta \tau 1 \kappa \eta \tilde{c}]^{1,87}$ (Sofista, $235 \mathrm{c} 9-\mathrm{d} 2)$

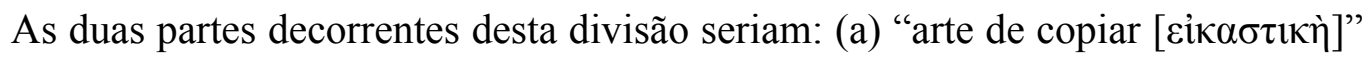

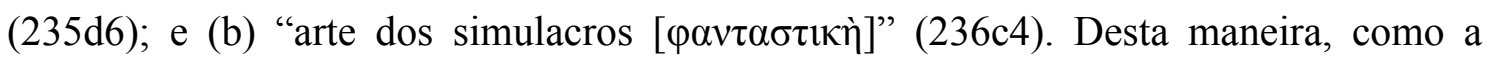
questão é a da divisão da arte de produzir imagens em duas espécies, pode-se dizer que o grande problema que a solução das duas aporias pretende resolver não deve ser o de garantir a mera possibilidade de produzir qualquer imagem, mas sim garantir que seja possível realizar dois tipos diferentes de produção: por um lado, de boas imagens, por meio da arte da cópia; por outro, de más imagens, por meio da arte do simulacro. No Sofista se fundamentará, portanto, algo que fica apenas indicado em outros diálogos platônicos: a possibilidade de uma boa e de uma má mimese ${ }^{88}$.

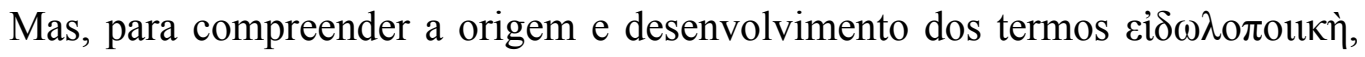

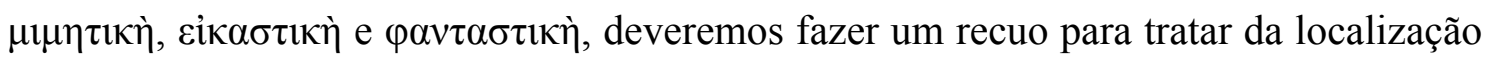
desses gêneros no interior da sétima definição de sofista.

No início do diálogo, antes de instituir qualquer definição de sofista, Platão estabelece uma averiguação do método que deverá ser utilizado para a definição, isto é, realizará um teste com o intuito de conferir se o método das divisões cumpriria a tarefa que lhe era requisitada: associar corretamente, pelo discurso, um nome a uma atividade ${ }^{89}$. Como modelo para a definição mais complexa, é proposto o estudo da definição de pesca à linha (218e2-5). Nesta antecâmara metodológica, visando a divisão da arte ( $\tau \dot{\varepsilon} \chi \vee \eta)$ em

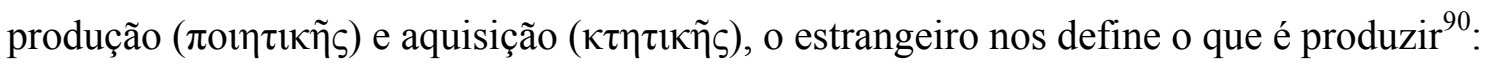

"De tudo que, não existindo antes, alguém depois leve à existência; dizemos que aquele que leva a existir produz e o que é levado é produzido" ${ }^{91}$ (Sofista, 219b4-6)

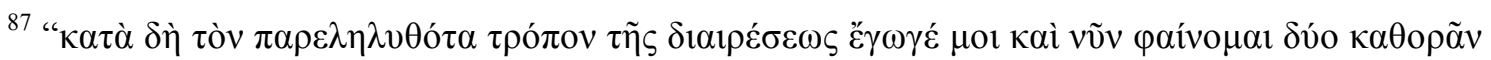

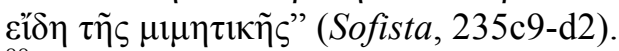

88 "The crucial distinction between eikastike and phantastike must be understood as the distinction between true and false mimesis" (PALUMBO, 2013, p. 269).

${ }^{89}$ 218b6-d6 e sua retomada em 221a7-b2

${ }^{90}$ Esta definição de produção do Sofista retoma o que já havia sido dito no Banquete (205b-c).

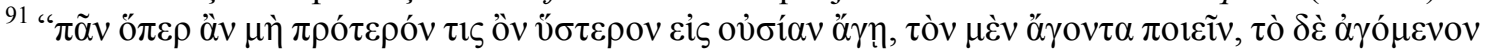

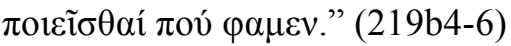


Esta fala do estrangeiro se sobressai às outras pelo poderoso arsenal ontológico empregado, até então oculto no diálogo. Entretanto, a frase, aparentemente, é inócua como um tiro na água. Pois é escolhido prosseguir por uma análise da aquisição ${ }^{92}$, e não da produção.

Para estabelecer a primeira definiç̧ão do sofista, o Estrangeiro, de maneira muito estranha, se limita a postular a semelhança entre pesca à linha e sofística, fazendo, então, a nova cadeia de divisões se iniciar pela quinta divisão da definição de pesca à linha: opta por começar pelo gênero da caça. Ou seja, aquela divisão preliminar do pescador à linha, inicialmente realizada apenas para testar a validade formal do método, é utilizada também como ponto de partida para os conteúdos da divisão que pretende definir o sofista.

Assim, enquanto estabelece a primeira definição do sofista (como caçador interessado de jovens ricos, 222a-223c), Platão desconsidera fazer um exame sobre as quatro primeiras divisões que lhe serviam de condição para a desejada definição, a saber: entre animados e inanimados; entre luta e caça; entre troca e captura; e entre produção e aquisição. Porém, o que para um leitor desatento poderia ser interpretado como uma falha na exposição platônica, na verdade pode ser explicado por meio das definições seguintes do sofista: o estrangeiro brilhantemente retoma uma a uma as divisões que estavam "pendentes". Ao que parece, segundo a regra exposta em 218c7-d2, a ordem destas análises parte do mais fácil em direção ao mais difícil de ser solucionado, o estrangeiro cerca o sofista de modo a encontrar o esconderijo em que este se abriga.

Ao problema dos inanimados, Platão não demonstra muito interesse (ver 220a1-

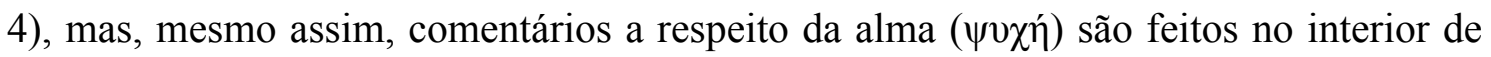
outras cadeias de divisão (223e1-6, sobre comércios dedicados à alma; ou, principalmente em 227a7-228a2, sobre a saúde, a doença e a purificação da alma). A questão da troca será relembrada em 223c6-7. Seu desenrolar (223c-224d) dará origem à segunda definição do sofista: como comerciante de ciência das virtudes ${ }^{93}$. Para a quinta definição

\footnotetext{
${ }^{92}$ As divisões seguem: "aquisição" se dividiria em "por troca" e "por captura"; "por captura", em "por luta" e "por caça"; "por caça", em "a inanimados" e "a animados"; "a animados", em "terrestres" e "marítimos"; "marítimos", em "que voam" e "que ficam na água"; "que ficam na água", em "que prende a presa" e "que fera a presa"; "que fere a presa", em "ao fogo" e "com fisga"; "com fisga", em "de cima para baixo" (por meio de tridente) e "de baixo pra cima" (por meio de anzol). E com este último teríamos chegado à definição de "pesca à linha".

${ }^{93}$ Como já foi dito anteriormente, a terceira e quarta definições parecem excertos da segunda definição.
} 
(de erístico mercenário) será levada em consideração a noção de luta (225a2-226a4). Na definição do sofista como purificador de almas pela refutação (a sexta, 226a-231c), o estrangeiro adiciona mais uma possibilidadade de divisão de artes. Ao considerar a arte

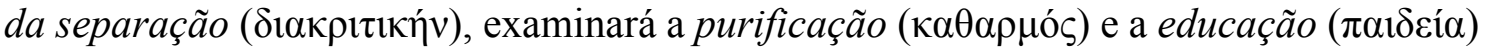
e isto terminará por aproximar perigosamente o sofista do filósofo (230e6-231a5). Convém notar que não somente todas as definições do sofista conferem a este um tom de equívoco moral que deve ser reprovado, mas também que tais definições retomam características já atribuídas ao sofista ao longo do corpus platônico ${ }^{94}$.

A referência à sexta definição do sofista, aquela que o classifica como contraditor

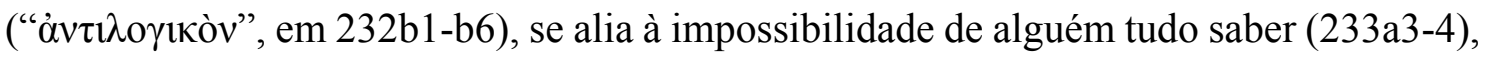
e introduz a questão que apontará para o parecer saber, e consequentemente, para a análise

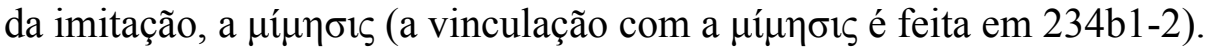

Pretendemos defender, com base na frase do estrangeiro de 233d9-10, a saber, "Se alguém afirmasse nem dizer, nem contradizer, mas, por uma só arte, fazer e conseguir conhecer todas as coisas..." (233d9-10) $)^{95}$, que neste momento há uma virada no texto e Platão se volta para a arte da produção com a qual ainda estaria em dívidas desde a sua primeira divisão (no exemplo da pesca à linha, em 218e-221c) ${ }^{96}$. Por meio desta interpretação, explicaríamos o motivo daquela frase protuberante em 219b4-6, justificaríamos o retorno das divisões para uma nova definição do sofista a partir de 264c (exatamente sob o jugo da produção) e o relembrar da mesma frase em 265b8-10. Obviamente, se aceitarmos tal interpretação, somos necessitados a compreender a maior e mais célebre parte do diálogo como um grande apêndice para solucionar a divisão das

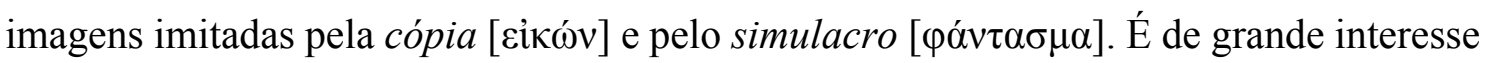

${ }^{94}$ Podemos fornecer alguns exemplos: caçador interessado de jovens ricos em Apologia de Sócrates (19e4-20a2) e Protágoras (316c5- d2); comerciante em Protágoras (313c4-6); erístico mercenário, pode ser encontrada no Eutidemo (272a5-b4), referindo-se aos irmãos Eutidemo e Apolodoro, sofistas segundo a personagem Críton (271c1); refutador e purificador de almas em Protágoras (312b8-c1); por comparação com as divisões a constituem, a sexta definição bem pode ser notada no diálogo Górgias (450a e 464b-c). Apesar da sétima definição parecer ser a mais característica do Sofista, podemos, também no Górgias, entrever algumas frases que já a antecipam. Por exemplo: a noção equivocada da retórica como a arte que abarca todas as outras (Górgias, 456a-c; Sofista, 233c); ou a abordagem da retórica como algo associado à imagem, ao

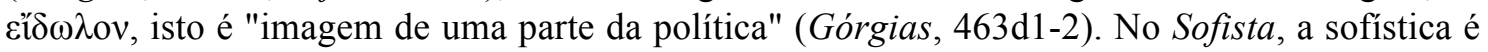
tida como "produtora de imagens"(Sofista, 268d1)

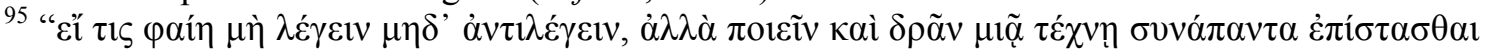
$\pi \rho \alpha ́ \gamma \mu \alpha \tau \alpha "$ (Sofista, 233d9-10).

${ }^{96}$ A retomada da arte da produção é confirmada em 265a4-5. 
notar que se esta distinção, operada no Sofista entre uma maneira correta e outra incorreta

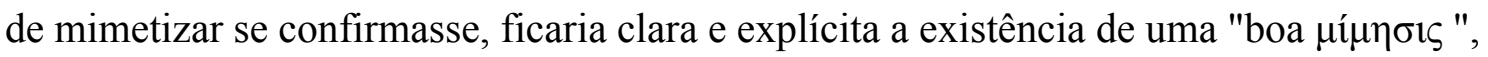
questão que atormentou e atormenta os estudiosos que buscam conciliar o livro $\mathrm{X}$ da

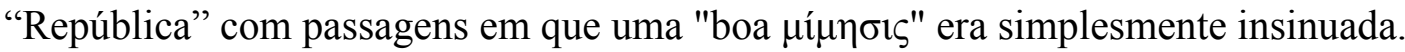

Assim, dizia Platão em 236c76-7:

"Então, eu chamava a essas duas formas da arte de fazer imagens

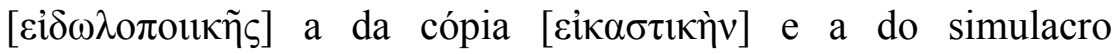

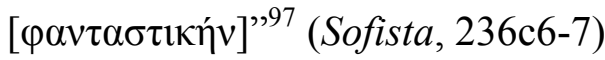

Será justamente esta fala que o Estrangeiro retomará quase no final do diálogo, em 264c4-5:

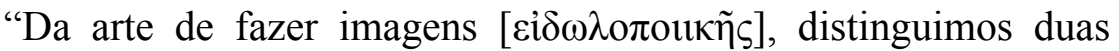

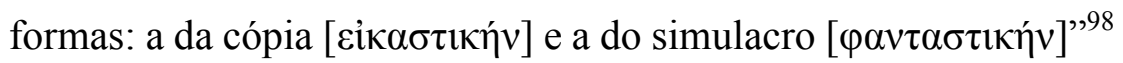
(Sofista, 264c4-5, modificamos a tradução da editora Gulbenkian ${ }^{99}$ )

Deste modo, pretendemos evidenciar o modo como a sétima definição foi interrompida, mas retorna exatamente do ponto em que parou para que seja feita a sua recapitulação. Entre estes dois trechos citados acima, a justificação da divisão da arte de produzir imagens (ou, se quiser, da arte mimética) em dois, por um lado, arte da cópia e, por outro, arte do simulacro, será o motor de todo o desenvolvimento lógico-ontológico do diálogo. Assim, em primeiro lugar é identificada a aporia do não ser: esta seria dedicada a garantir a existência de uma arte do simulacro ( $\varphi \alpha v \tau \alpha \sigma \tau 1 \kappa \eta ̀)$, produtora de falsidades. Por consequência da primeira aporia cairemos também na segunda, a aporia

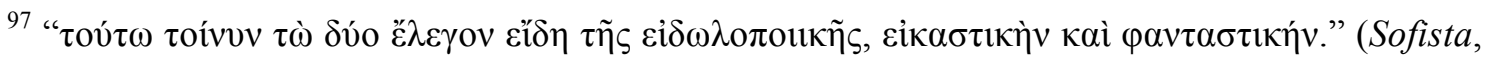
236c6-7)

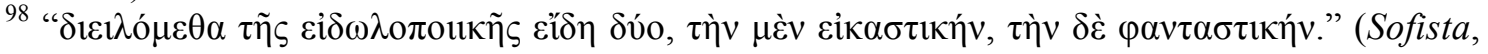
264c4-5)

${ }^{99}$ Cabe notar que a tradução portuguesa não captou a referência a 236c6-7. No grego, os mesmos termos de 236c foram utilizados, mas os tradutores responsáveis optaram pela seguinte opção:

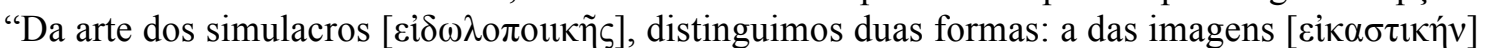

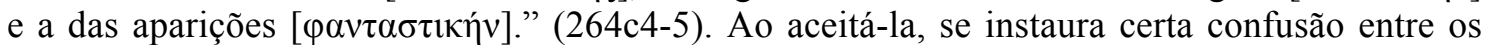
termos conceituais estabelecidos no início do diálogo, confusão esta que tem um alto preço a pagar: não identificar a retomada da divisão interrompida em 236e.
} 


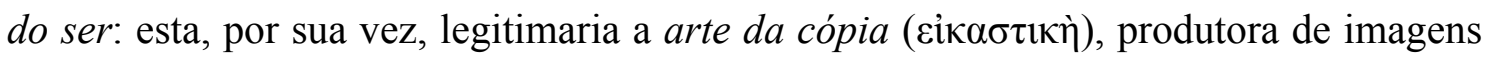
verdadeiras. A resolução das duas aporias exigirá a construção de uma ontologia que permita, de algum modo, a mistura de ser e não ser.

No entanto, após a retomada da definição interrompida, ao prosseguir na cadeia das divisões, Platão realiza uma mudança fundamental que complica o entendimento daquele trecho que nos direcionava à primeira aporia (233d-236e): ao que parece, não

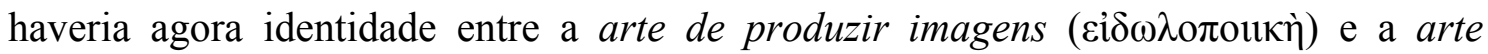

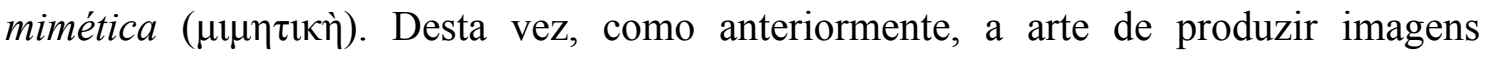

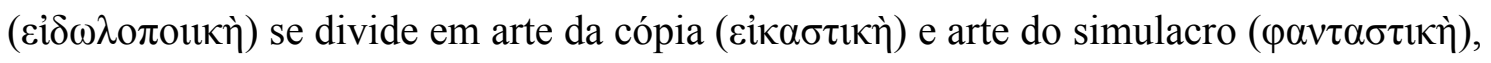
no entanto, o mimético ( $\mu$ $\mu \eta \tau$ ıòv, em 267a10) é apenas uma parte da arte do simulacro

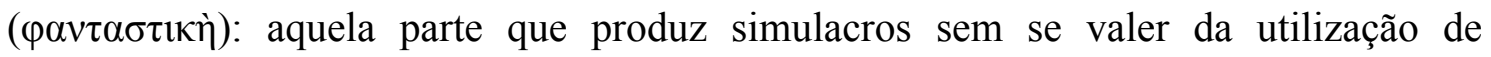
instrumentos. Entretanto, neste caso, duas perguntas continuam a intrigar:

(i) Produzir imagens falsas com a utilização de instrumentos não faria parte da mimética? Por exemplo, a pintura não seria uma arte mimética?

(ii) Realizar uma cópia fiel não seria também uma forma de imitação?

Uma proposta de solução para este impasse, este titubear platônico no lugar confiado à imitação, nos é fornecido por Monique Lassègue: aquele que que produz simulacros sem ao auxílio de instrumentos é um mímico (LASSÈGUE, 1991, p. 256257). Deste modo, a estudiosa pretende resguardar a arte mimética como sinônimo de arte da produção de imagens. Não somente uma parte da arte dos simulacros, mas também envolvendo a arte da cópia, o que poderia ser entendido como uma boa mimese. A tentativa de Lassègue não é completamente convincente, mas fornece alguma resposta para a dificuldade do texto platônico. Uma outra resposta poderia ser a de que Platão, de fato, oferece, na recapitulação oferecida no final do diálogo, uma correção daquilo que teria dito antes da primeira aporia. Nesta última opção, não haveria boa mimese. Haveria sim boas imagens, mas a mimese estaria inserida como parte da produção de imagens falsas, ou seja, seria uma parte da arte dos simulacros. Lidia Palumbo também vê o 
mesmo problema e, para resolvê-lo, enfatiza o "sobretudo" ( $\mu \alpha \dot{\lambda} \iota \sigma \tau \alpha)$ da frase em 267 a89 com o objetivo de defender que haveria um outro tipo imitação, uma boa imitação ${ }^{100}$.

De qualquer forma, de modo independente do problema da mimese, se juntarmos a passagem inicial que trata da produção de imagens (235c-236e), passagem esta que gerou as duas aporias, com a aplicação da solução ontológica dessas aporias ao âmbito discursivo (realizada a partir de 259e), parece ser possível estabelecer que Platão está operando uma analogia clara entre imagem e discurso no Sofista ${ }^{101}$. Isto fica claro quando, em 234c5-6, o Estrangeiro se utiliza da expressão "imagens faladas" ( $\varepsilon$ ‘ $\delta \omega \lambda \alpha \lambda \varepsilon \gamma o ́ \mu \varepsilon v \alpha$ ) ao comparar a pintura com o discurso. A grande tarefa do diálogo será, portanto, demarcar com clareza a distinção entre uma boa e uma má imagem, uma boa e má mimese ${ }^{102}$, ou seja, por analogia, marcar a distinção entre um discurso verdadeiro e um discurso falso.

Esta analogia, no entanto, só poderá ser efetivada pois Platão parece compreender

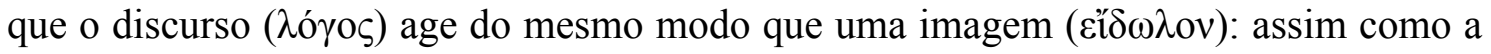
imagem, todo discurso se refere a algo externo a ele mesmo ${ }^{103}$. Será tal tarefa comparativa que permitirá distinguir a figura do sofista, aquele que produz imagens ruins e discursos falsos, da do filósofo, aparentemente, o produtor por excelência da boa cópia e do discurso verdadeiro.

Seria interessante, portanto, investigar a maneira como o filósofo organiza seu

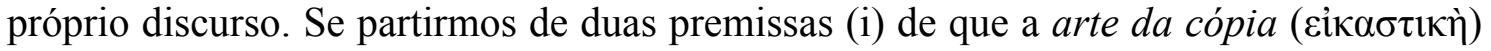

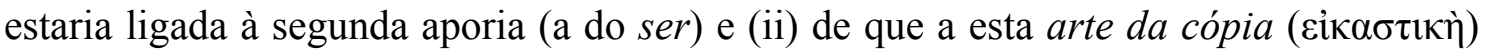
estaria vinculada à atividade, por excelência, do filósofo ${ }^{104}$, teríamos então de ter uma íntima ligação entre a articulação discursiva utilizada por Platão, o filósofo, no próprio diálogo e os conteúdos ontológicos que forneceram uma solução para a segunda aporia. Isto é, seríamos direcionados a encontrar uma coerência profunda entre o método

\footnotetext{
100 "It is interesting to notice that Plato emphasizes how it is this specific aspect of phantastike "above all" (malista) which is called mimesis (267a8-9). In my opinion this means not only that there are other aspects of the phantastike that are called mimesis which can be described and understood as "imitation", but also that there are mimeseis which are not aspects of phantastike, and which are not false" (PALUMBO, 2012, p. 277)

${ }^{101}$ Sobre este tema é indispensável o livro de Anca Vasiliu (VASILIU, 2009). Para a tese contrária, de que imagem e discurso não devem ser comparados, temos opinião de William Bondeson (BONDESON, 1972).

${ }^{102} \mathrm{Na}$ visão de Lidia Palumbo: "both the true and the false image are mimemata, but only in the case of the true image does the soul receive a mimema that corresponds to reality" (PALUMBO, 2013, p. 270).

${ }^{103}$ No entanto, a questão permanece: o discurso seria imagem de quê?

${ }^{104}$ A premissa (ii) é conjectural: provável, mas não textual.
} 
discursivo que estrutura o diálogo, ou seja, a divisão dialética, e a solução ontológica conferida, no Sofista, ao impasse gerado pela dramática relação entre os objetivos platônicos e a filosofia de Parmênides. Comecemos, portanto, por compreender o

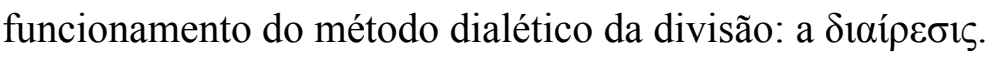




\section{INTERMEZZO DIALÉTICO}

Bem conhecida é a passagem do Fedro na qual Platão distingue claramente entre dois tipos de dialética:

"Sócrates: Primeiro, a uma só ideia em visão de conjunto levar o que está disperso em multiplicidade, para que definindo cada unidade se ponha em claro aquilo que em cada caso se quer ensinar" ${ }^{, 105}$ (Fedro, 265d3-5)

"[quanto ao segundo modo] O oposto: por espécies poder recortar segundo as articulações naturais e tentar não quebrar nenhuma parte, como faz um mau cozinheiro" $" 106$ (Fedro, 265e1-3)

"Disso é que eu mesmo sou amante, ó Fedro, dessas divisões e conjunções que me qualifiquem para falar e pensar; e se algum outro eu considero capaz de ver um naturalmente sobre muitos, a este eu o persigo 'atrás de seus passos como aos de um deus'. E o que é certo também é que os capazes de fazer isto, deus sabe se os designo corretamente ou não, mas até o momento os chamo dialéticos. 107 (Fedro, 266b3-c1) ${ }^{108}$

Nesta passagem, com o intuito de diferenciar os dois tipos de dialéticos, Platão se vale da ambiguidade semântica do verbo que no infinitivo da voz média, $\delta 1 \alpha \lambda \varepsilon ́ \gamma \varepsilon \sigma \theta \alpha$,

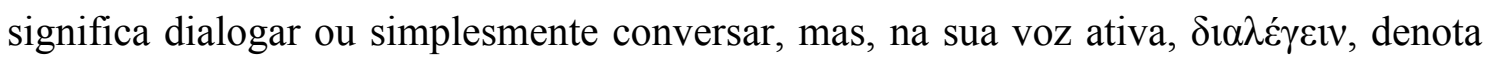
escolher, selecionar, separar ou até mesmo examinar (cf. AUBENQUE, 2012, p. 238, nota 7). Ao primeiro modo está associado o ato de olhar as coisas em conjunto

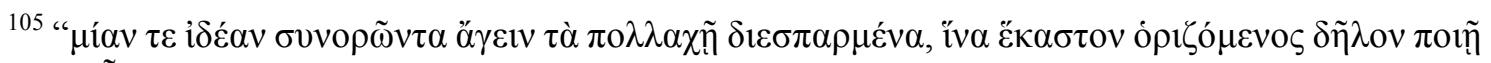

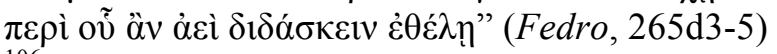

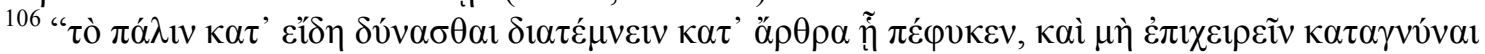

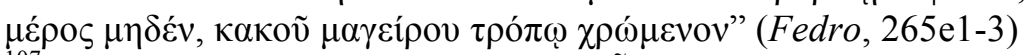

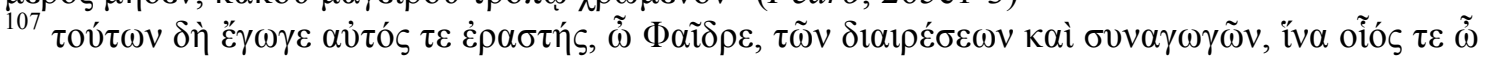

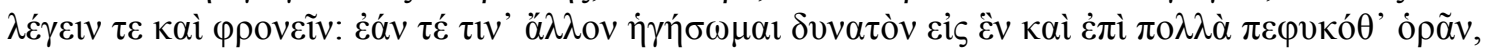

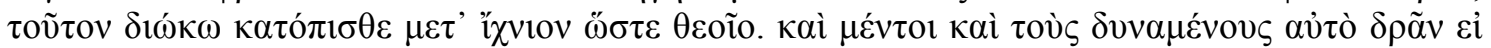

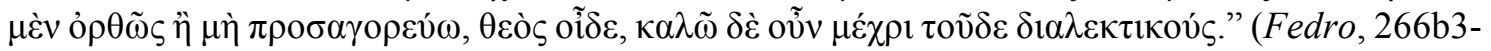
c1)

${ }^{108}$ Utilizamos a tradução do professor Cavalcante de Souza (PLATÃo, 2016)
} 


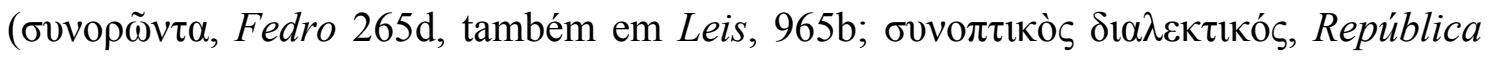
237c), que, grosso modo, está vinculado à obtenção de uma ideia a partir de um tipo de reunião da multiplicidade sensível. Quanto ao segundo modo dialético, a ele está associado o chamado método da divisão ( $\left.\delta \iota_{\alpha} i ́ \rho \varepsilon \sigma ı\right)$ ).

Pode-se dizer com tranquilidade que tal método de destrinchar uma unidade em suas multiplicidades terá prevalência principalmente nos diálogos considerados tardios, particularmente no Sofista, Político e Filebo. Mais do que uma simples presença fortuita, no entanto, talvez possamos encarar este aparecimento tardio como uma misteriosa novidade a ser decifrada.

Talvez com certo exagero, mas não sem algum fundo de verdade, Pierre Pellegrin (PELLEGRIN, 1991, p. 412) brinca com uma possível mudança do subtítulo atribuído,

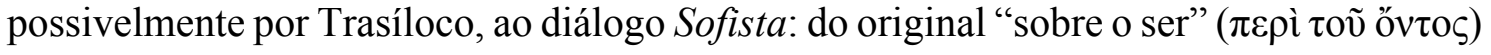

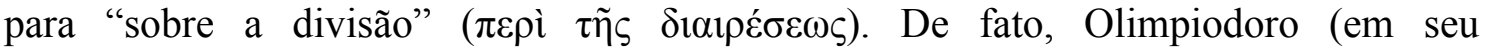
Prolegômenos), mesmo que assumindo uma posição contrária a seu emprego, nos relata

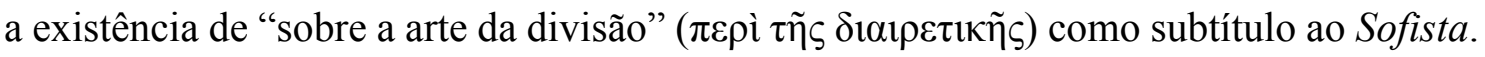
Podemos ver também, numa tradução árabe de uma obra de Galeno, a atribuição de "sobre

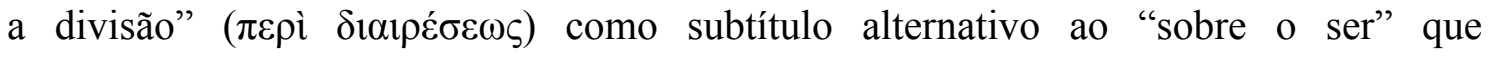
frequentemente encontramos nos manuscritos medievais do Sofista (ALLINE, 1984, pp. 127-128). Essa interpretação de Pellegrin nos sugere o quanto pode ser esclarecedor ligar a ontologia tardia de Platão a tal método conhecido como o "da divisão". Entretanto, de todo modo, parece ser muito forte afirmar, como quer Pellegrin, a prevalência da divisão

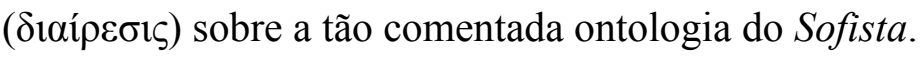

Por outro lado, de maneira oposta, é forte na literatura a posição interpretativa de Gilbert Ryle, que tem a pretensão de postular a irrelevância do método da divisão para a resolução de qualquer problema filosófico que se queira verdadeiramente sério. Isso valeria até mesmo para os objetivos específicos da recém-nascida filosofia antiga (RYLE, 2009, p. 43): para Ryle, nem Platão, nem a filosofia do século XX teria algo a fazer com este procedimento precursor da taxonomia biológica de Lineu.

Se, de certa forma, o distanciamento que Ryle toma do método da divisão cumpre a função de impossibilitar uma continuidade entre os gêneros supremos e dos demais gêneros (o que corroboraria a diferenciação estabelecida por Wittgenstein entre mostrar e dizer), de outra, busca garantir que os gêneros supremos, tomados por Ryle como tipos categoriais, não estabeleçam qualquer relação entre si. Pois, afinal, correríamos o risco 
de que o entrelaçamento entre eles nos reenviasse em direção à uma unidade primeira não predicativa e não articulável pelo discurso. Deste modo, para Ryle, o fosso entre os gêneros supremos e os demais gêneros não deveria ser apenas de grau, mas de natureza: os gêneros supremos eram lidos como conceitos formais e relacionais que não funcionariam segundo o modelo da divisão gênero/espécie ${ }^{109}$.

Não há dúvidas de que, no Sofista, o método da divisão estruturará o texto platônico como um todo. Ele é testado no início do diálogo (no caso do pescador à linha, $218 \mathrm{c}-221 \mathrm{c})$ e será utilizado como modelo $(\pi \alpha \rho \alpha ́ \delta \varepsilon 1 \gamma \mu \alpha)$ para se chegar às várias definições de sofista: será justamente essas definições que irão conferir uma estrutura geral, ou uma ossatura, ao diálogo. No entanto, pouco é falado no Sofista sobre as características fundamentais de tal método e, quando algo a respeito disso é comentado,

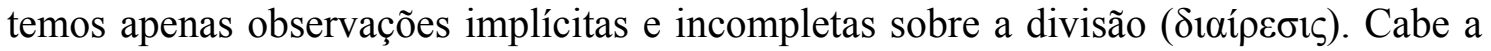
nós saber se por detrás da função organizativa que as divisões proporcionam há, de fato, alguma afinidade entre as novidades ontológicas do diálogo e o método que nele é utilizado.

A primeira informação relevante sobre o método da divisão nos é oferecida pouco antes de Platão colocá-lo em prática: quais são os objetivos de tal método? O que pretendemos solucionar a partir de sua aplicação? O que ganhamos ao utilizá-lo? Diz o Estrangeiro sobre o problema relativo ao gênero do sofista:

"Mas, primeiro, parece que deves começar agora por examinar em comum comigo acerca do sofista, buscando

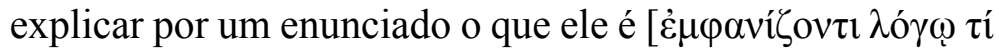
$\pi \mathrm{o} \tau^{\prime} \grave{\varepsilon}_{\sigma \tau 1}$. Pois, até agora, em comum, tu e eu temos acerca

109 Antonia Soulez pontua, ao lado de Julius Moravcsik, que a distinção entre relação e propriedade, utilizada na leitura de Ryle, não existe para a Grécia antiga: "L'idée du peu d'importance que présenterait pour le dialicien la tâche de division [o que é a interpretação de Gilbert Ryle], vient tout droit de cette distinction moderne entre propriétés et relations. C'est bien elle en effet qui permet de comprendre que dans le Sophiste, les concepts tenus par Ryle pour philosophiquement intéressants sont, croit-il, nettement et exclusivement relationnels." (SOULEZ, 1991, p. 223) 


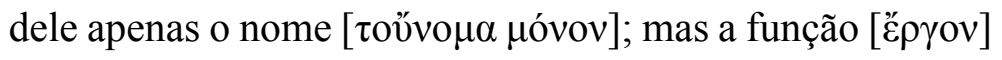
que lhe atribuímos será particular a cada um de nós. É preciso sempre, acerca de tudo, estar de acordo sobre o próprio facto $[\pi \rho \tilde{\alpha} \gamma \mu \alpha]$ mais por enunciados $[\delta i \grave{\alpha} \lambda \hat{\gamma} \gamma \omega v]$ do

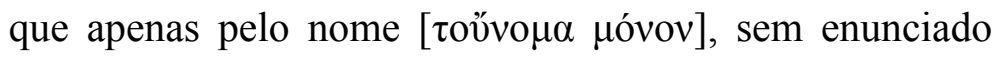

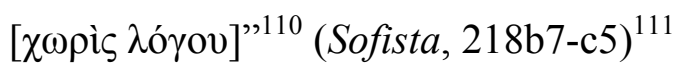

Em primeiro lugar, devemos notar neste trecho a uso de um vocabulário típico das

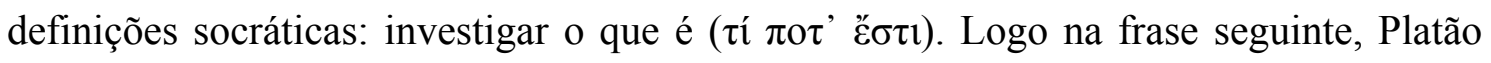
especifica melhor o que o termo quer dizer. O objetivo pretendido seria aquele de encontrar uma atividade para cada nome, ou melhor, para ser mais preciso, verificar se para cada nome distinto temos uma atividade correlata ao respectivo nome.

A questão que está em vista é aquela exposta no início do diálogo (217a7-9): para três nomes distintos ("sofista", "político" e "filósofo"), teríamos um, dois ou três gêneros correspondentes? Aos olhos de Platão, não basta que estejamos em acordo quanto à utilização dos mesmos nomes ("sofista", "político", "filósofo"), devemos estar em concordância por meio do discurso, ou argumento ( $\lambda$ ó $\gamma \circ$ ) ), utilizado para tratar das coisas. No contexto do diálogo, o método da divisão seria justamente o discurso ( $\lambda$ ó $o \zeta)$ que nos

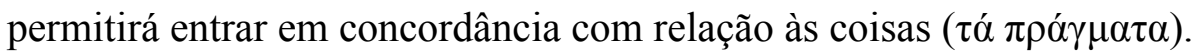

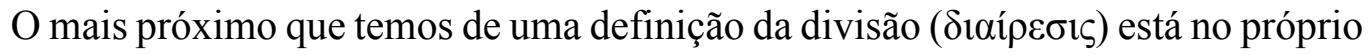
Sofista:

\footnotetext{
"Hóspede de Eleia: O acto de fazer divisões segundo os gêneros e de não considerar a mesma forma diferente, ou outra a mesma, acaso diremos que não é da ciência dialética?

Teeteto: Sim, diremos.

Hóspede de Eleia: Pois bem, aquele que é capaz de fazer isso percebe suficientemente uma forma através de muitas, estando uma

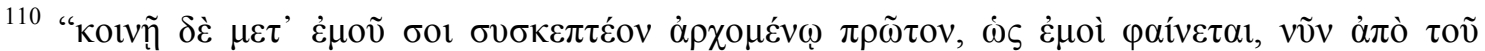

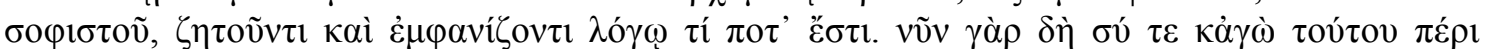

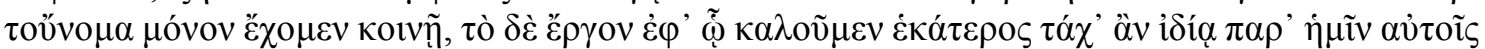

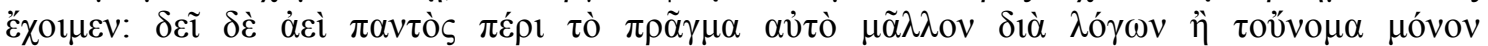

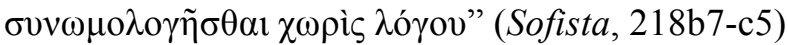

${ }^{111}$ Este trecho será retomado em 221 b, pois acredita-se que o objetivo do método foi cumprido no caso do pescador à linha.
} 
disposta, separada de cada uma, estendida por tudo, e muitas formas diferentes, contidas entre si por uma só de fora, e uma estendendo-se através de muitos todos, ajustados em conjunto numa forma só; e muitas formas separadas em tudo. Isso é saber e ser capaz de discernir cada coisa que comunga e cada coisa que não comunga, segundo o gênero"112 (Sofista, 253d1-e2)

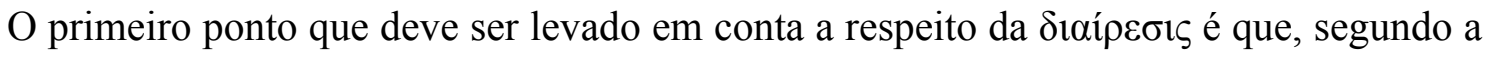

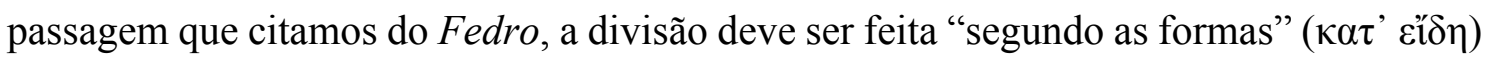

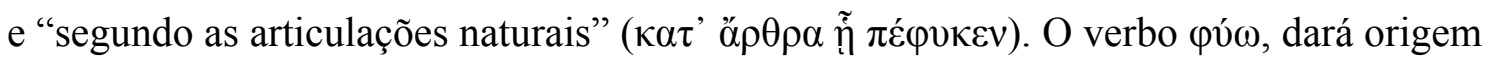

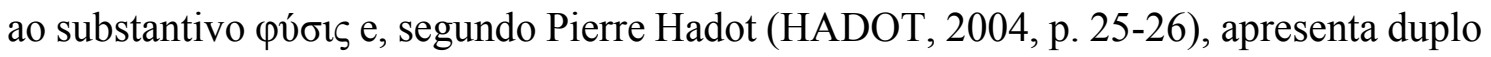
significado: não só "aparentar um aspecto", mas também algo em torno de "crescer", "brotar", "formar" ou "engendrar". Assim, o primeiro sentido faz prevalecer as características de algo, já os demais evidenciam o processo de constituição desta coisa.

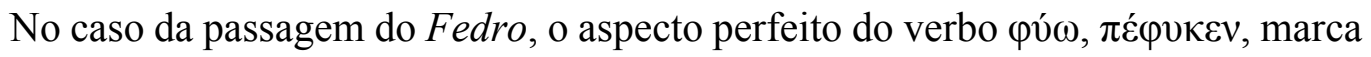
o resultado de um ato, direcionando, portanto, a interpretação da frase para a compreensão de que as articulações já estão constituídas, e não em processo de crescimento ou formação. Ou seja, podemos dizer que, no método da divisão, devemos desmembrar algo respeitando as conjunções que constituem esta coisa, separando corretamente cada parte que lhe é característica.

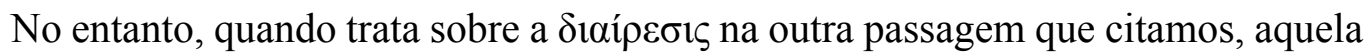
do Sofista, Platão afirma que a divisão se faz "segundo o gênero", ou segundo os gêneros

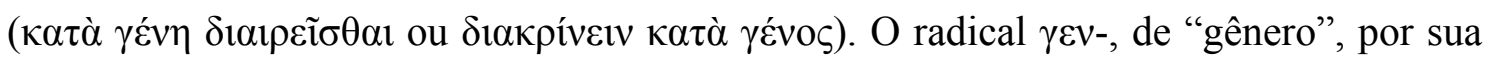
vez, é tido como signo da noção de geração ou de vir-a-ser. É bem previsível, no entanto, que uma sociedade gestada nos versos da Teogonia de Hesíodo compreenda que a constituição e aspectos de algo não estão dissociados do seu processo de geração a partir de noções pré-existentes. Assim, os elementos que dão origem à determinada coisa

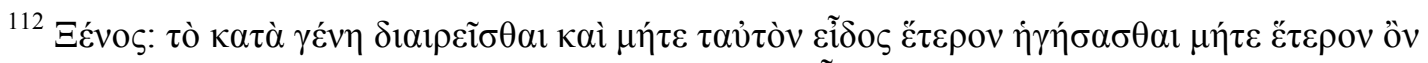

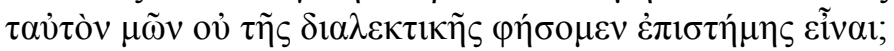

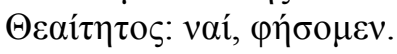

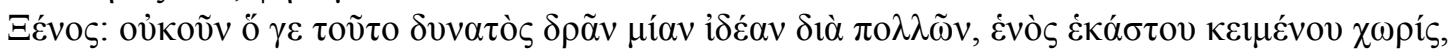

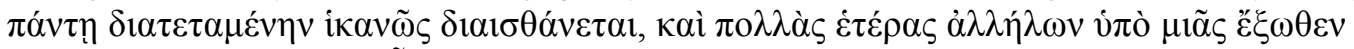

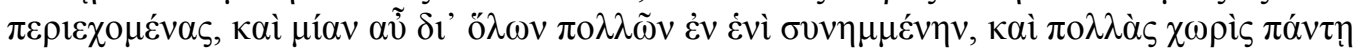

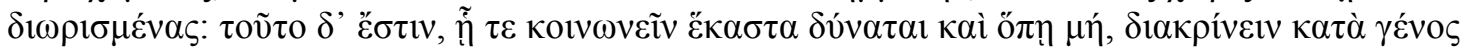

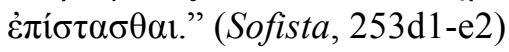


naturalmente são constituintes de sua própria natureza visível, se fazendo, assim, sempre presentes.

Para ficar claro, cabe notar que, tanto no Sofista quanto no Político, não há distinção semântica entre $\gamma \varepsilon ́ v o \zeta$ e $\varepsilon \tilde{i} \delta o \varsigma^{113}$ : tais termos são perfeitamente intercambiáveis ${ }^{114}$. Não há nenhum problema em enxergar aí certa indistinção entre processo e produto, desde que entendamos que a divisão deva ser feita para distinguir as características daquilo que pretende ser conhecido.

É deste modo que não podemos deixar de ouvir nestas passagens de Platão, os ecos do método exposto no fragmento 1 de Heráclito (DK B 1): fazer a divisão "segundo

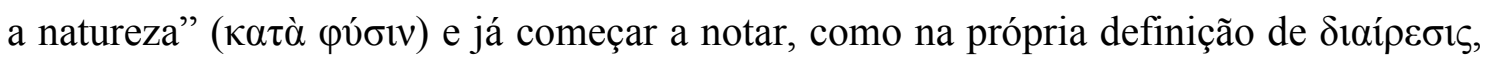
vamos nos direcionando para a questão do movimento e repouso, que será trabalhada no Sofista a partir de 249b. Além do mais, como veremos, nos distanciamos cada vez mais do velho Parmênides, que dizia em seu fragmento 8 (DK 8, v. 22), que o ser não é

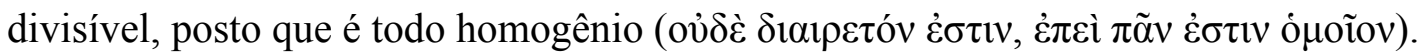

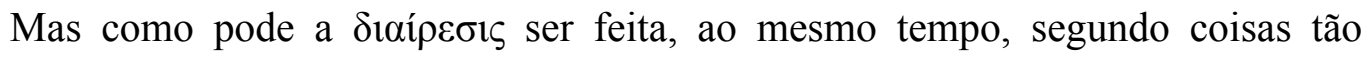

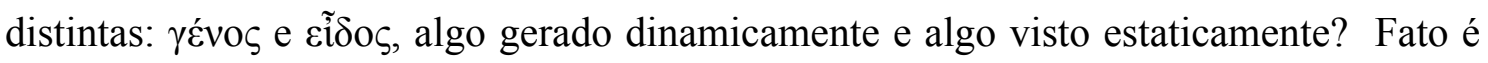
que nos diálogos em que o método da divisão aparece com toda a sua força, como no Sofista ou no Político, os objetos de tal divisão não são seres abstratos como "A Justiça" ou "O Amor", mas sim figuras bem conhecidas, como o político ou o sofista; ou técnicas

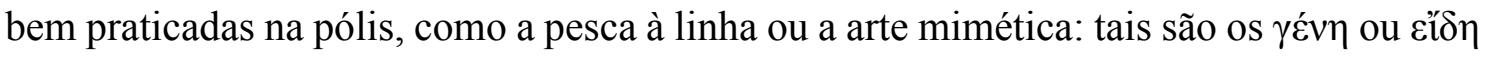
em questão. Tais objetos, dignos de ser divididos, não são simplesmente ideais, mas estão logo ali, são coisas que apresentam certa materialidade e estão próximas de quem quiser conferi-las ou frequentá-las.

O escrutínio desta indistinção entre $\gamma \varepsilon ́$ vo e $\varepsilon \tilde{i} \delta o \varsigma$ pode ganhar força ao identificarmos que cada um destes termos está tematizado na parte relativa à batalha entre os partidários do corpo e os partidários das formas (a partir de 246a), no Sofista. Dado que Platão associa o corpo àquilo que é gerado, como poderia se valer da indistinção entre os dois termos se ali, nesta seção, o próprio Platão os exibe como contraditórios, alvo de controvérsia entre escolas de pensamento? Por hora, guardemos esta questão.

\footnotetext{
${ }^{113}$ Assim é a posição de Auguste Diès em sua Notice ao Político (PLATÃO, 2012b, p. XVIIIXIX) e de John Ackrill em In defense of platonic divison (ACKRILL, 1970, p. 389).

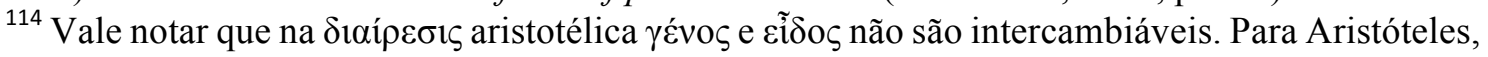

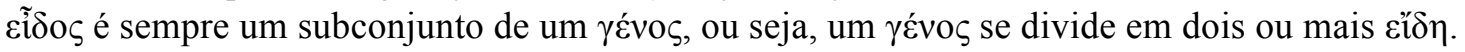


O segundo ponto que queremos comentar diz respeito às noções de unidade e de multiplicidade, noções que sempre aparecem ao lado da explicação do método da divisão. Esta é mais uma querela dos antigos, tematizada no Sofista (a partir de 242c) como uma controvérsia entre as escolas filosóficas: partidários do um versus partidários do múltiplo. Se bem lembrarmos, tal questão aparece também nas já citadas passagens que tratam da dialética, tanto na versão do Fedro quanto na do Sofista. Para Platão, o dialético:

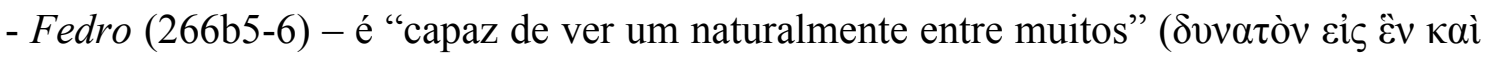

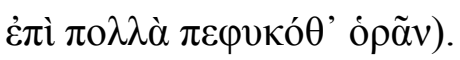

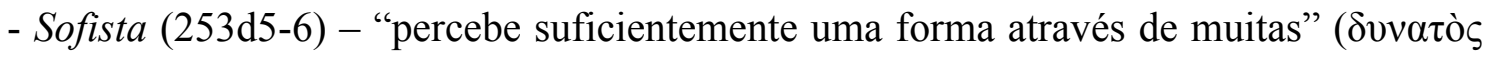

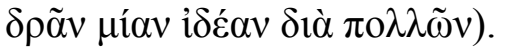

Desta forma, a dialética consiste sempre em intermediar entre o um e o múltiplo: seja juntando os múltiplos numa unidade, seja dividindo uma unidade para encontrar a sua multiplicidade. Nisto parecem consistir os dois tipos de dialética. E não é necessário que tal unidade seja abstrata, invisível e inacessível perceptivelmente. Como Platão diz no Filebo (15a4-7), consideremos não somente o belo enquanto unidade ou o bom como unidade, mas também o homem como unidade ou o boi como unidade.

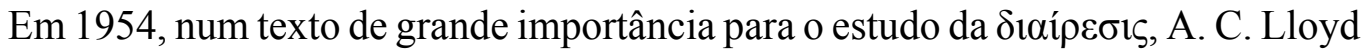
(LLOYD, 1967, p. 221) cita a seguinte passagem do Filebo:

"Sócrates: (...) E os mais antigos, que eram superiores a nós e habitavam mais perto dos deuses, transmitiram esta tradição: 'as coisas que se pode sempre dizer que são vêm do um e do múltiplo, e têm nelas mesmas um limite e uma ilimitação inatos'. Se as coisas foram belamente dispostas em tal ordem, devemos, então, admitir sempre, para cada caso, apenas uma forma para cada uma delas e devemos buscá-la; e certamente a encontraremos presente. Se, então, a apreendermos, devemos depois de uma, examinar duas, se houver; caso não haja duas, devemos examinar três ou qualquer outro número. Devemos examinar da mesma maneira cada uma delas até que se veja essa unidade original, não apenas como uma, 
múltipla e ilimitada, mas também que se vejam quantos elementos ela tem; mas não devemos aplicar a forma do ilimitado à pluralidade antes de percebermos o número total da pluralidade que existe entre o ilimitado e o um, e só então podemos nos despedir dessas coisas e abandonar cada uma delas no ilimitado. Como disse, os deuses ofereceram-nos essa tradição para examinarmos, aprendermos e ensinarmos uns aos outros. Mas os sábios atuais produzem o um e o múltiplo ao acaso, mais rápido ou mais lento do que deveriam fazer. Vão de imediato do um ao ilimitado, deixando escapar os intermediários." ${ }^{115}$ (Filebo, 16c7-17a3) ${ }^{116}$

Tal passagem é fundamental para compreendermos como unidade $\mathrm{e}$ multiplicidade estão imbricadas no contexto da divisão. A passagem do Filebo parece, portanto, estar fazendo referência aos intermediários que devem ser considerados quando se pretende definir algo, ou seja, entre todos aqueles componentes que são elencados como constituintes do gênero sofista. No entanto, para se chegar em cada um destes inúmeros componentes, Platão nos oferece uma divisão mais simples, normalmente dividindo cada unidade em duas metades. Mas como, na prática, operar a passagem do um ao múltiplo e irmos chegando aos muitos intermediários constituintes do sofista? Isto é, como dividir de modo que tenhamos a garantia da passagem do um para o múltiplo de maneira segura, com todos os intermediários? Qual é a medida correta para a divisão de um gênero qualquer?

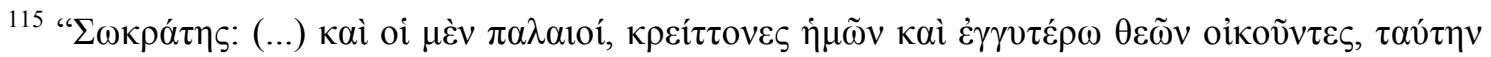

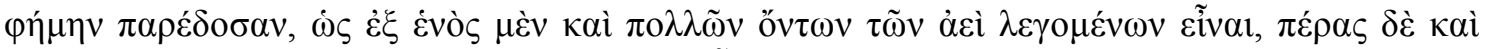

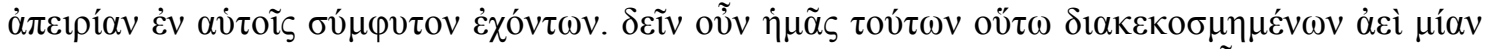

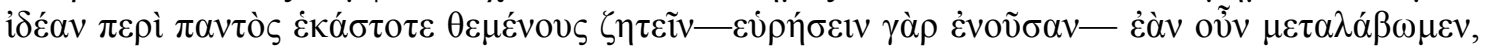

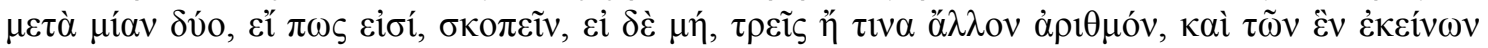

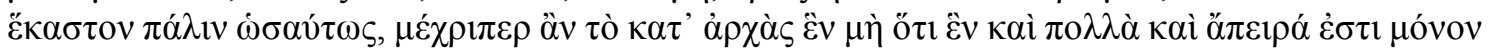

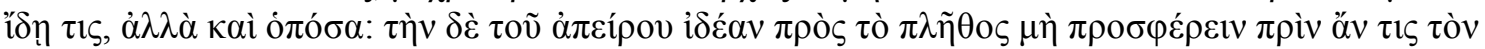

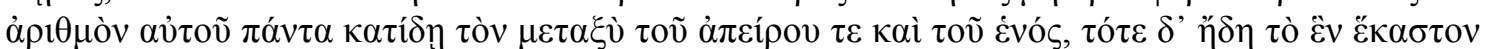

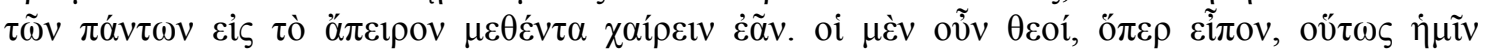

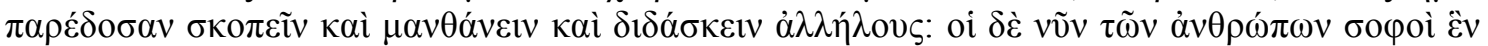

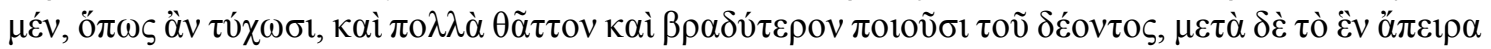

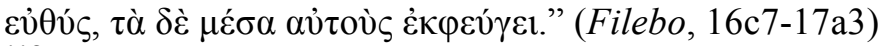

${ }^{116}$ Tradução de Fernando Muniz (PLATÃO, 2012a).
} 
A questão que diz respeito ao modo correto de dividir cada um dos gêneros foi tratada com maior ênfase em algumas partes do Político. Diz Platão: "Se dividiria, de certa forma, belamente, e sobretudo segundo a forma ( $\left.\kappa \alpha \tau^{\prime} \varepsilon \varepsilon^{\prime} \delta \eta\right)$, e dicotomicamente ( $\delta i ́ x \alpha)$, se os números se repartirem em pares e ímpares" ${ }^{\prime 17}$ (Político, 262e). Seguindo o princípio da economia, devemos primeiro tentar dividir em dois (e esta é a verdadeira dicotomia). Mas, se as partes resultantes não assumirem algum tipo de unidade interna, ou certo espírito de comunidade, deve estar sempre aberta ao método a possibilidade de dividir em 3 ou mais partes, até que se encontre algo que se dignifique a receber o nome de forma ou espécie ( $\varepsilon \tilde{i} \delta$ os). Dizia Platão no Político:

"Então, posto que não é possível dividir em dois, por membros nós dividiremos, como a uma vítima de sacrifício. Pois devemos, acima de tudo, dividir sempre pelo menor número."118 (Político, 287c3$5)^{119}$

No entanto, da passagem entre 262d-e do Político é possível depreender a exigência de certa consistência, ou certa comunhão interna entre as partes daquilo que foi dividido, para que o método da divisão seja aplicado corretamente. Afinal de contas,

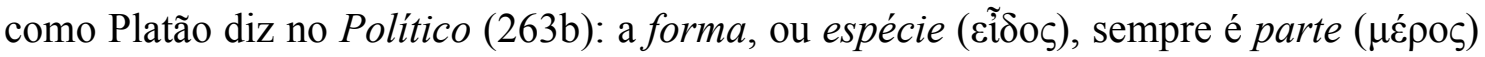
daquela coisa da qual é a forma, entretanto uma parte qualquer de algo nem sempre pode ser considerada uma espécie consistente. Ou seja, na divisão aplicada corretamente, o gênero deverá ser, ao mesmo tempo, parte e forma: aquilo que é fruto da divisão deve ser também um produto consistente que apresente certa unidade. Portanto, podemos dizer que se gênero e espécie são palavras intercambiáveis nos textos tardios de Platão, por outro lado, espécie e parte não significam, de maneira alguma, a mesma coisa. Toda espécie é uma parte, mas nem toda parte é uma espécie.

Isto não quer dizer, todavia, que só exista uma única e rígida maneira de se dividir corretamente um determinado gênero. Desde que se preserve a unidade das partes, podemos dividir corretamente de diversos modos. Isto ocorre, por exemplo, no Sofista

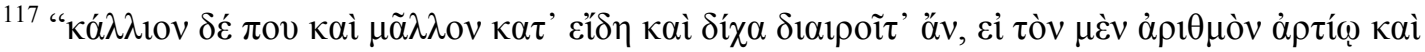

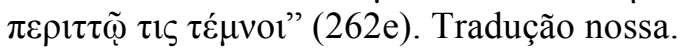

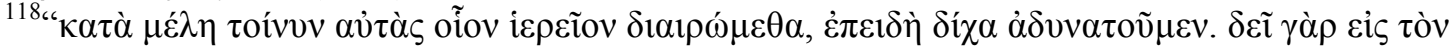

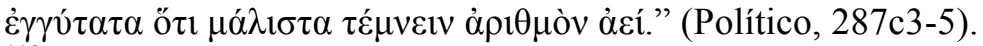

${ }^{119}$ Tradução nossa.
} 
(266a1-2), quando a arte produtiva é dividida em divina e humana, mas logo em seguida

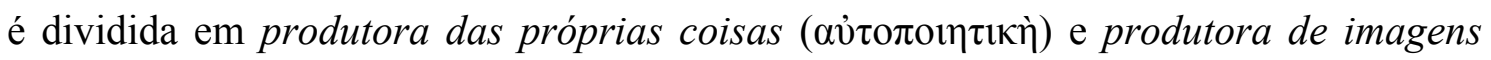

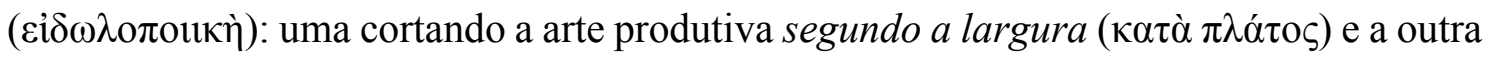

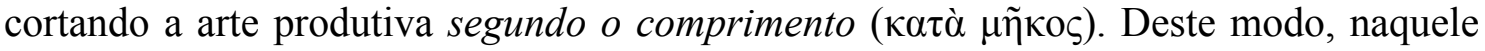
contexto, a arte produtiva se divide em divina e humana, mas tanto a parte divina quanto a parte humana se dividem em produtora das próprias coisas e em produtora de imagens.

Podemos dizer que o modo como devem ser feitas as divisões também pode ser explicitado por meio da distinção, feita por Platão no Sofista, entre alguns tipos de oposição. Em 236e5 acontece uma mudança de vocabulário fundamental para o prosseguimento do diálogo: se, para se referir ao sofista como contraditor, Platão se

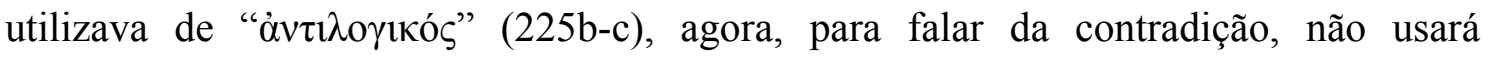

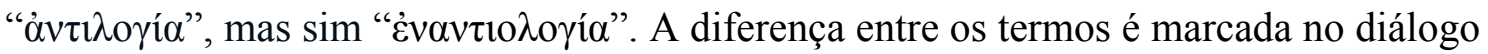
pois não se trata aqui da discórdia ou da controvérsia, oposição externa entre discursos, mas sim de uma contradição, ou oposição, interna ao próprio discurso.

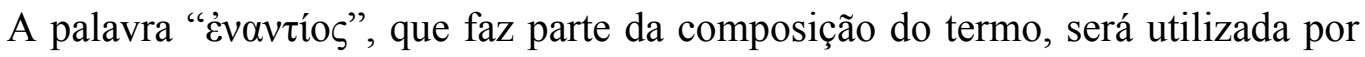
Platão de forma decisiva para indicar as oposições entre termos, notadamente na enunciação dos gêneros supremos), que serão fundamentais para o desenvolvimento do

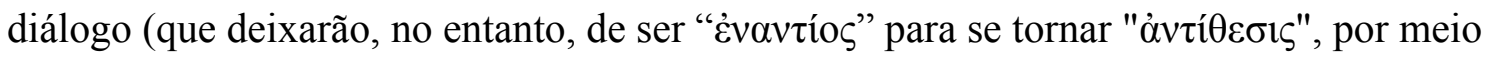

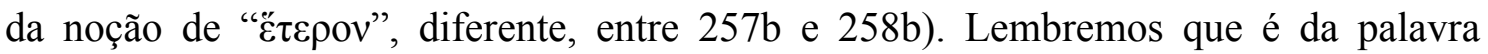

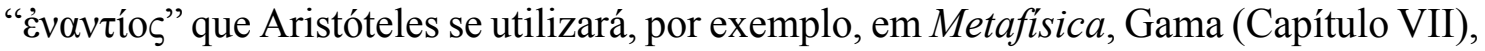
para indicar a noção de contradição.

Essa mudança terminológica marca, ao nosso ver, a passagem de um tom mais frouxo da controvérsia entre discursos para um tom mais rigoroso, que visa a necessidade de uma coerência interna de um discurso que se pretenda bem estruturado e verdadeiro. Esta primeira dificuldade (ả $\pi$ opías, em 236d9-237a1) se dá pois parece ao estrangeiro

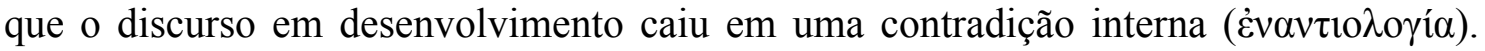
Daquele ponto de vista, dado que o não ser, por definição, não é, se o não ser é (237a3-

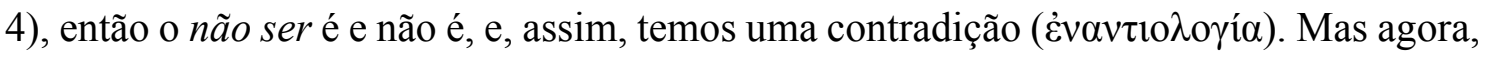
nos dirigindo para o final do diálogo, temos o seguinte: 
"Sempre que dizemos o não ser [ $\mu$ ஸ̀ òv], não dizemos algo contrário

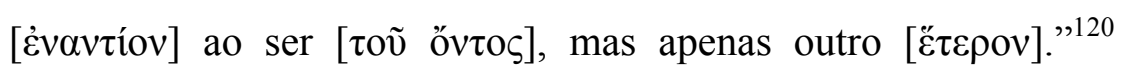
(Sofista, 257b3-4)

Daquela dificuldade, e de sua aparente contradição em 236e, se seguia, no diálogo, o problema de nomeação do não ser (237b10-c4). No entanto, o texto entre 257b-

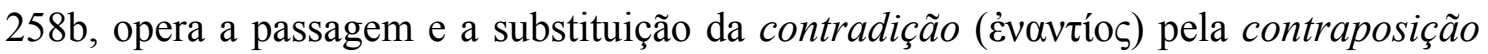

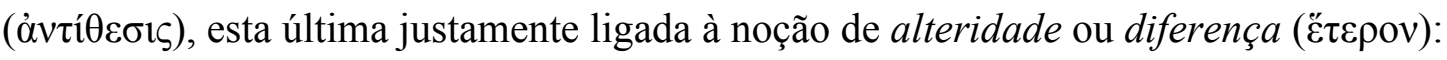

"Hóspede de Eleia: Então, não acontece com isto que o não belo

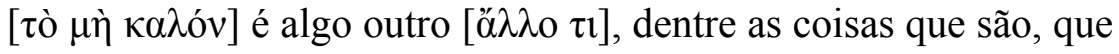
foi separado [ả

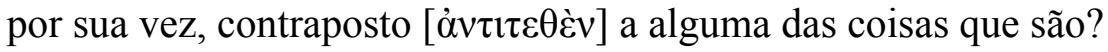
Teeteto: É sim.

Hóspede de Eleia: Então segue-se que o não belo é uma certa

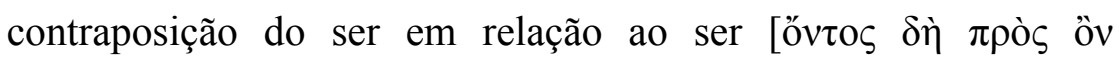
$\dot{\alpha} v \tau i ́ \theta \varepsilon \sigma ı)]$.

Teeteto: Corretíssimo.

Hóspede de Eleia: Pois então?! Segundo esse discurso, portanto, estará o belo mais dentre as coisas que são e o não belo menos?

Teeteto: Em nada." ${ }^{121}$ (Sofista, 257e2-11)

Antes de qualquer coisa, cabe notar que, no trecho acima (257e2), Platão utiliza " “’ $\lambda \lambda \mathrm{o}$ " (outro de vários) para marcar a diferença entre as coisas, mas, um pouco mais a frente, em 258a5, e no mesmo sentido, volta ao vocabulário padrão marcado pela palavra "Өá $\varepsilon \rho \rho v "$ (o outro de dois), sem prejuízo de rigor terminológico. Devemos notar também

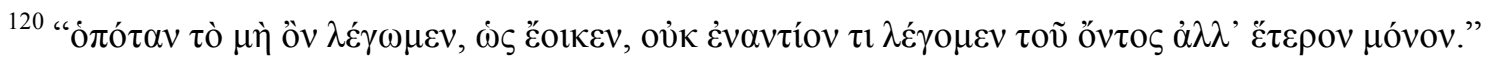
(Sofista, 257b3-4).

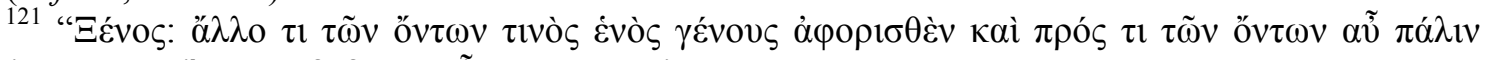

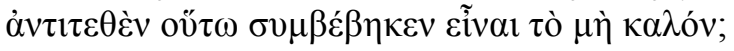

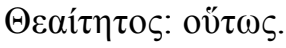

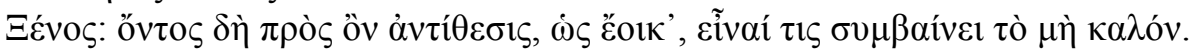

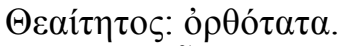

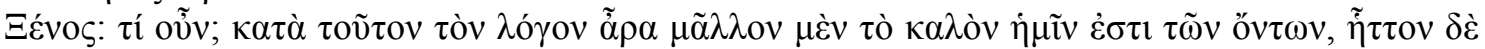

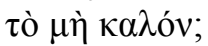

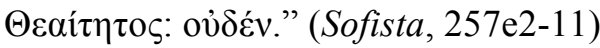




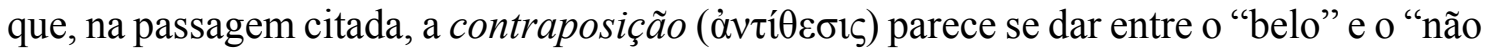
belo", ambos participantes do ser, o que poderíamos chamar de uma contraposição horizontal, entre dois termos de mesmo nível. Assim, para seguir o exemplo, "belo" e "não belo" se contraporiam, mas ambos participariam de um gênero superior que os teria dividido e diferenciado. No entanto, o funcionamento da contraposição continua sendo explicitado na obra platônica:

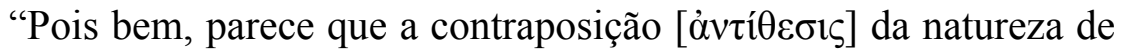
uma parte do outro à do ser, contrapondo-se um ao outro, em nada é, se é permitido dizer, menos entidade do que o próprio ser, não

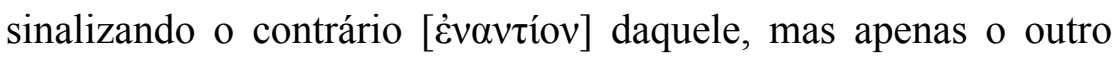

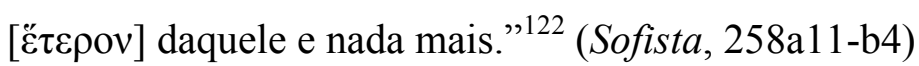

Nesta passagem, de difícil interpretação, temos uma importante referência para o modo como Platão compreende a contraposição ( $\dot{\alpha} v \tau i ́ \theta \varepsilon \sigma ı \varsigma)$ e como isso se relaciona com o vocabulário ontológico do diálogo. Como não podia deixar de ser diferente, há uma grande disputa entre os comentadores quanto à interpretação do texto. Apesar de envolver diversos comentadores, a polêmica é protagonizada por Denis O’Brien e Nestor Cordero, este último segue a leitura proposta pela tradução de Auguste Diès.

Como já havíamos visto, a divisão platônica se dá sempre "segundo a natureza"

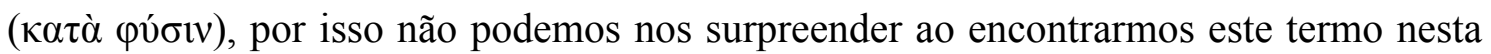
passagem. A questão diz respeito basicamente ao modo como é entendido os genitivos da primeira parte da oração, isto é, se o genitivo "da parte" ( $\mu$ opíov) passaria ou não para o

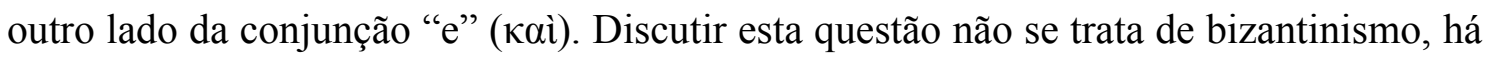

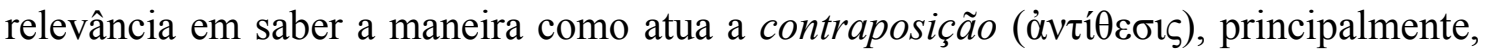
como é o caso, quando se trata da relação entre os gêneros supremos.

Podemos expor a questão do seguinte modo: a antítese seria entre natureza da parte do outro e a natureza da parte do ser (ou seja, horizontalmente de parte com parte)

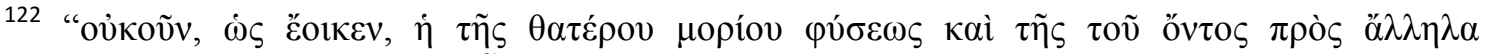

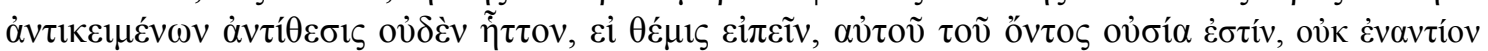

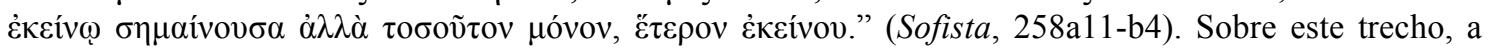
polêmica Cordero-O’Brien (O' BRIEN, 1999, p. 27-28; PLATON, 1993, nota 330).
} 
ou entre a natureza da parte do outro e a natureza do ser (ou seja, uma contraposição como que diagonal, da parte de um gênero com seu gênero superior)?

Da leitura de Cordero depreende-se que a antítese é de parte com parte, da de O’Brien que é de uma parte com a natureza do ser. Nesta última, o ser apareceria como particular (segundo ele diz, "o ser de cada objeto") um pouco mais a frente do texto (em 258e2-3). Acreditamos que a leitura sintática de O'Brien se mostra a mais correta para a compreensão da primeira parte da frase, mas não nos comprometemos com sua interpretação geral que vê "duas definições de não ser" escalonadas, uma geral e a outra particular na sequência do texto platônico. Assim, ao nosso ver, o texto de 258e2-3 apenas retoma o de 258a11-b4.

A continuação da frase também não é fácil de passar despercebida: Platão diz que essa contraposição "é nada menos essência (oủoía) que o próprio ser". Difícil é saber o que Platão quis dizer com isso. Aparentemente, o Estrangeiro quer dizer que a contraposição do outro, que é derivado do ser, com o ser não é menos ser que o ser que é constituinte da oposição. Desta maneira, ao contrapormos as coisas poderíamos captar a essência do que é.

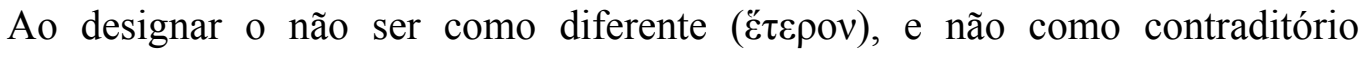
(Ẻvaví́ov), Platão parece estar pretendendo conferir ao não ser (tomado como alteridade) um papel determinante para qualquer consideração a respeito do ser. Não é a toa que, no contexto geral do diálogo, fazer com que o não ser seja e o ser não seja se apresente como condição para que possamos veicular não apenas discursos falsos, mas também discursos verdadeiros que não sejam tautológicos. Deste modo, a existência da antítese garantiria que algumas coisas se combinariam, participando umas das outras, enquanto outras formas não se combinariam entre si, mas seriam parte de um gênero superior em comum $^{123}$.

\footnotetext{
${ }^{123}$ Um dos grandes estudiosos da divisão platônica, Julius Moravcsik, tem opinião contrária: "Finally, this survey of the passages on naming and cutting reveals the glaring absence of any connection between the relationships between Forms that is being established here and the relation of participation. The usual technical terminology indicating participation - which is very much present in the discussions of the 'megista gene' of the Sophist - is simply absent from the passages dealing with divisions. This absence must be accounted for by any adequate interpretation." (MORAVCSIK, 1973, p. 165). Acreditamos que a posição de Moravcsik foi

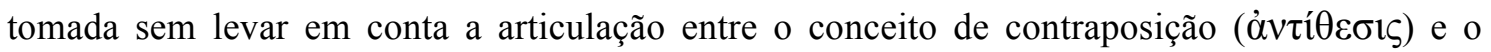
método da divisão. Ao identificarmos aquilo que chamamos acima de contraposição diagonal, pretendermos mostrar que a estrutura proporcionada pela divisão dos gêneros apresenta as condições para que se possa dizer que há coisas que participam e outras que não participam de
} 
Dois tipos de contraposição, portanto: uma que chamaríamos de horizontal, na qual os gêneros não se misturariam entre si; a outra, chamada por nós de diagonal, na qual haveria mistura e entrelaçamento entre os gêneros de níveis diferentes. Do ponto de vista dos gêneros que não se misturam, como não apresentam ligações imediatas entre si, podemos dizer que estes são contraditórios ( $\dot{\varepsilon} v \alpha v \tau i ́ o v)$ entre si. Logo, caberia ao dialético e a sua arte identificar as relações entre os gêneros, ou seja, verificar se participam ou não participam entre si. Portanto, o verdadeiro filósofo poderá apreender a constituição desta rede ontológica, composta de gêneros e espécies que se combinam ou não se combinam reciprocamente.

No nível mais geral dos diversos modos discursivos da Atenas clássica, parece ser possível associar estes três modos de oposição a três tipos de discurso: a controvérsia

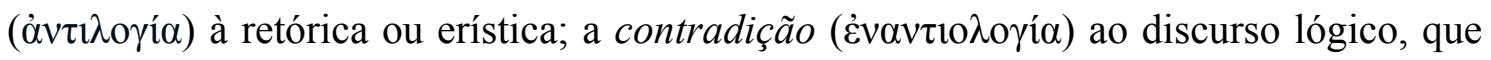
está aí ainda em processo de constituição; e a contraposição ( $\dot{\alpha} v \tau i ́ \theta \varepsilon \sigma ı)$ à dialética.

Platão, no entanto, ao longo do Sofista, parece transformar as antilogias, as querelas entre as diversas escolas filosóficas em antíteses, quer dizer, o um e o múltiplo, o todo e as partes, o corpo e a forma, o movimento e o repouso, por exemplo, passam a ser complementares, e, cada um destes pares, juntos, se entrelaçam na unidade do ser. Veja bem, isto não quer dizer que sejam conciliáveis entre si, isto é, não podemos dizer que o repouso participa ou combina com movimento, entretanto eles coexistem e compõem um outro gênero ao qual ambos participam. Isto é evidenciado pela seguinte passagem da obra de Platão:

"Hóspede de Eleia: O quê? Algum dos dois [movimento e repouso]

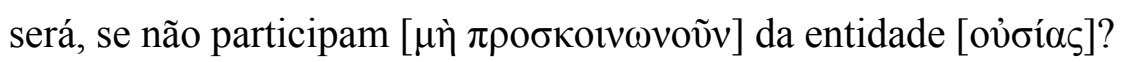
Teeteto: Não será.

um gênero qualquer. 


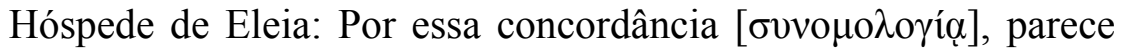
que imediatamente todas as coisas se levantam de novo: ao mesmo tempo, os que movem o todo e os que, como um, imobilizam, quantos, de acordo com as formas, dizem que as coisas são sempre segundo elas mesmas, do mesmo modo: pois, todos esses acoplam

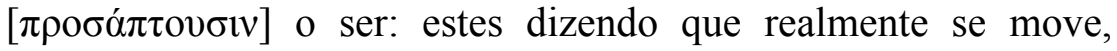
aqueles que realmente está em repouso." "124 (Sofista, 252a2-10)

A mistura do movimento e do repouso com ser é confirmada um pouco mais a frente:

Hóspede de Eleia: Os gêneros supremos daqueles que agora mesmo enumeramos são o ser, ele próprio, e o repouso e o movimento.

Teeteto: São.

Hóspede de Eleia: E, pelo menos dois deles, são reciprocamente sem mistura [à $\mu \varepsilon i ́ \kappa \tau \omega]$.

Teeteto: E muito.

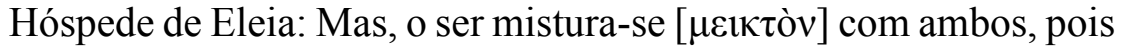
de algum modo ambos são.

Teeteto: Como não?"125 (Sofista, 254d4-11)

A mesma coisa vale para o mesmo e o outro:

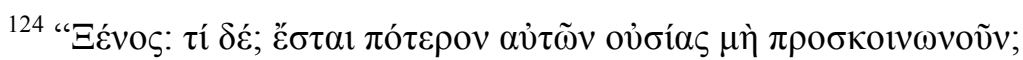

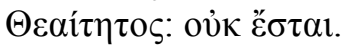

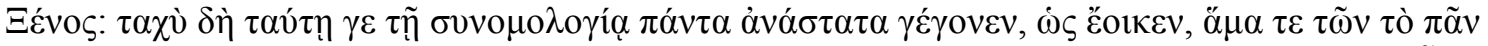

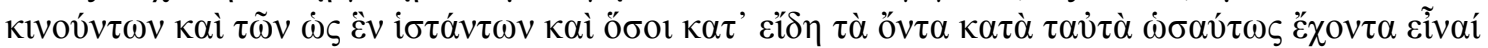

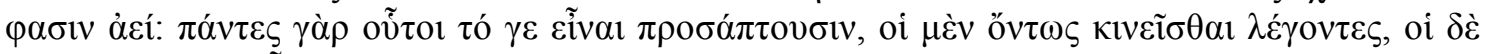

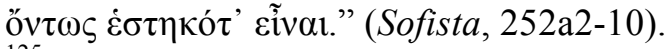

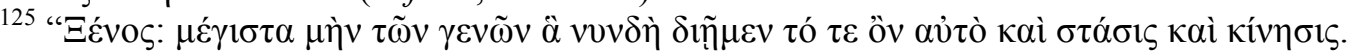

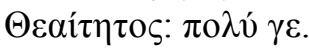

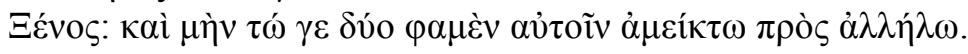

$\Theta \varepsilon \alpha i ́ \tau \eta \tau о \zeta: ~ \sigma \varphi o ́ \delta \rho \alpha \gamma \varepsilon$.

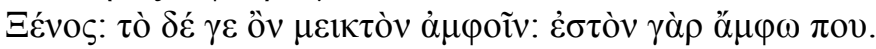

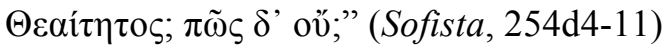


"Hóspede de Eleia: Mas, eu creio que tu admites que, dentre os que

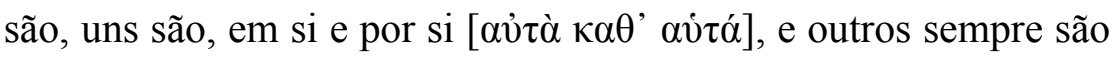

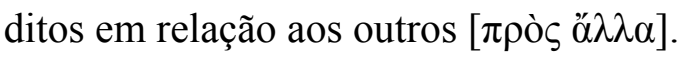

Teeteto: Porque não?

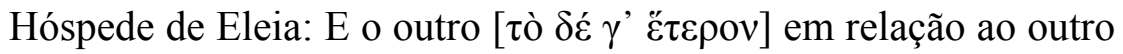

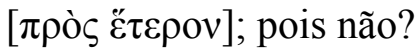

Teeteto: É assim." ${ }^{126}$ (Sofista, 255c14-d2)

No entanto, como muitos comentadores não deixaram de notar, é difícil enquadrar os chamados gêneros supremos na relação gênero/espécie proporcionada pelo método da divisão ${ }^{127}$. Mais do que isso, há dificuldade de estabelecer qualquer relação entre os gêneros supremos. Se com o ser, tanto movimento e repouso quanto o mesmo e o outro, se misturam, estes não podem ser simples partições do ser. Ao consideramos partições ou espécies do ser, teríamos que determinar qual é o tipo de relação existente entre estas partes. Para escapar desta complicada tarefa, os comentadores costumam afirmar que os gêneros supremos são completamente independentes entre $\mathrm{si}^{128}$. Assim, por exemplo, é a posição de Marcelo Pimenta Marques:

“As objeções de Aristóteles, que são, na verdade, as mesmas que Espeusipo havia feito anteriormente, supõem uma função e um alcance para a divisão que Platão nunca pretendeu que ela tivesse. Platão não se propõe construir uma estrutura ontológica totalizante, através da divisão. A igualdade de extensão dos gêneros do ser, da identidade e da diferença, no Sofista, e a unicidade de cada um deles são incompatíveis com uma hierarquização ou dependência

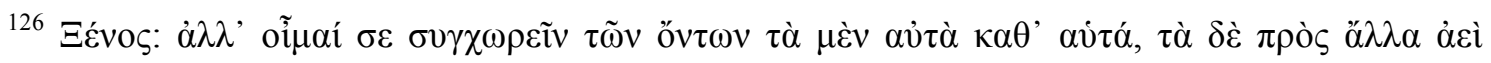

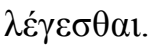

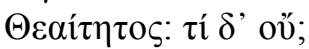

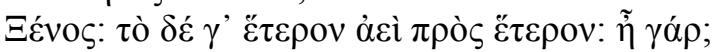

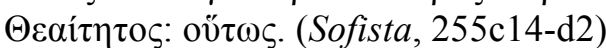

${ }^{127}$ Agradeço a Victor Gonçalves de Sousa que, pouco antes do encerramento desta dissertação, me apresentou um importante argumento contra a leitura dos gêneros supremos a partir da relação gênero/espécie.

${ }^{128}$ A leitura categorial dos gêneros supremos, como foi encampada por Gilbert Ryle, depende desta independência. No entanto, nem todos que postulam esta independência devem se comprometer com a leitura categorial de matriz ryleana.
} 
ontológica entre eles. Mesmo o Movimento e o Repouso, embora menos extensos, não são menos independentes.

Em suma, é de fundamental importância para a diferenciação entre a divisão usada por Platão e a que é revista por Aristóteles compreender que os gêneros maiores, no Sofista, não são obtidos através da divisão. Um gênero não é uma divisão, nem uma espécie do outro; um não é derivável do outro e nem é o princípio do qual o outro é derivado; cada um deles é o princípio de um aspecto determinado, irredutível ao outro, tal como o Estrangeiro irá estabelecer cuidadosamente etapa por etapa. Principalmente, uma vez que ser, identidade e diferença têm o máximo possível de extensão, não podem ser derivados de um outro princípio ideal qualquer, que supostamente estaria acima deles, mas cada um tem seu modo próprio de determinar a totalidade do campo ideal." (PIMENTA MARQUES, 2006, p. 65)

Entretanto, se, de fato, não podemos diferenciar extencionalmente cada gênero supremo - o que joga contra o método da divisão, que parece se pretender também extensional -, ainda causa espanto que há certas relações entre eles que lembram aquelas proporcionadas pela divisão. Em primeiro lugar, parece haver uma relação de oposição entre dois pares: movimento/repouso; mesmo/outro. Em segundo lugar, como já dissemos acima, todos eles parecem se misturar com o ser (o quinto gênero). Além do mais, ao apresentar os gêneros supremos, Platão parece fazer uma relação com aqueles gêneros dos quais estava tratando anteriormente no diálogo:

"Então, já concordámos que, de entre os gêneros, uns aceitam comungar entre si e outros não, e que uns comungam com poucos e outros comungam com muitos, nada impedindo que outros estejam em comunicação com todos [ $\pi \tilde{\alpha} \sigma l \quad \kappa \varepsilon \kappa o เ v \omega v \eta \kappa \varepsilon ́ v \alpha l]$. Depois disso, estendemos a nossa teoria, considerando desse modo não todas as formas, a fim de não nos atrapalharmos com muitas, mas, tendo escolhido algumas dentre as mais importantes. Em primeiro lugar, de que qualidade é cada uma, depois, de que modo 
tem comunicação recíproca. Isto, para, se não formos capazes de captar com toda a clareza o ser e o não ser, não ficarmos faltos de argumentos a respeito deles. E vejamos, tanto quanto a presente investigação consente, se nos é permitido dizer que o não ser é realmente não ser, retirando-nos sem danos."129 (Sofista, 254b8-d2)

Afinal de contas, por que motivo Platão usaria o mesmo termo, gênero, termo técnico no método da divisão, para tratar de algo que não significaria e não se comportaria da mesma forma? Deste modo, nossa posição quanto a este problema consiste em, primeiro, identificar que há uma série de oposições entre escolas filosóficas elencadas pelo Estrangeiro de $242 \mathrm{~b}$ em diante que são refutadas uma a uma. No entanto, parece haver uma retomada de algumas destas oposições com o aparecimento do exemplo dos gêneros supremos (movimento versus repouso, o mesmo versus o outro já haviam sido tratados anteriormente). Acreditamos que há um novo tratamento da oposição entre estes termos: Platão não compreende mais essas oposições como controvérsia ( $\left.\dot{\alpha} v \tau \imath \lambda \mathrm{o} o i^{\prime} \alpha\right)$ ou

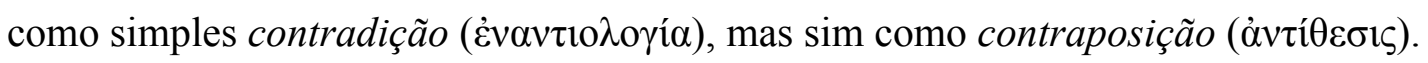

Assim sendo, a junção de tais termos opostos, independentes entre si, se fundem no gênero do ser. E do gênero do ser, então, todas as coisas existentes seriam derivadas. Mas o ser, ao nosso ver, seria a composição somente entre dois destes termos opostos, o que quer dizer, justamente, que não devemos considerar, por exemplo, que cada um dos outros quatro gêneros supremos seja uma parte do ser (que, deste modo, teria sido dividido em quatro), nem que sejam uma espécie que teve origem da divisão do ser.

Em nossa leitura, contudo, é da comunhão de dois termos contrapostos que o ser, partindo da reunião de dois outros gêneros, é composto. Portanto, de maneira ainda um pouco turva para nós, todas aquelas oposições elencadas pelo Estrangeiro (242c-251d) se empilhariam duas a duas, antiteticamente, na composição do $\operatorname{ser}^{130}$. Como todas as coisas

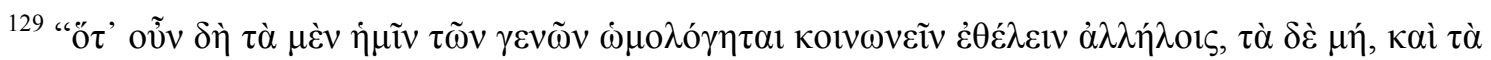

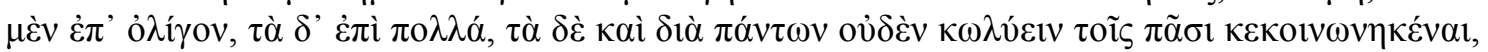

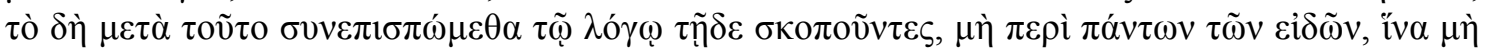

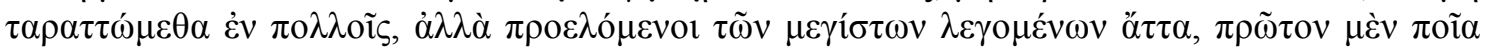

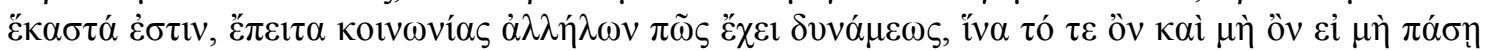

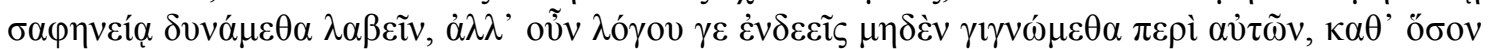

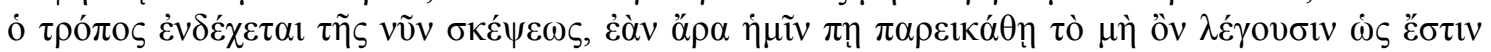

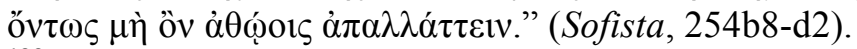

${ }^{130}$ Não é clara para nós a relação entre os diversos pares de opostos, por isso chamamos de "empilhamento", pensamos somente que suas extensões teriam de ser idênticas. A relação entre
} 
existentes participam do ser, então tal funcionamento antitético serviria de modelo para tudo aquilo que é, garantindo, assim, a extensão máxima ${ }^{131}$ de cada um destes conceitos.

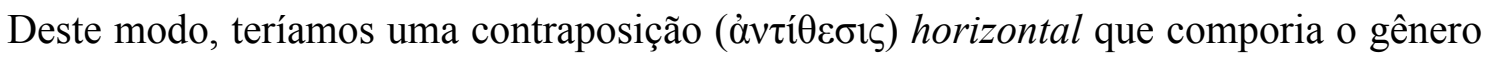
do ser e tais pares de opostos estariam em todas as coisas que são e que, portanto, participam diagonalmente do gênero do ser. Isto que acontece com o caso do ser serve, portanto, de modelo para todas as coisas que são.

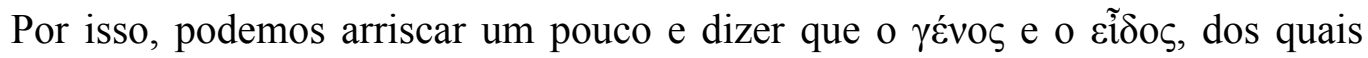
falávamos no início deste capítulo, também deixariam de ser contraditórios e passariam a coabitar cada coisa que é. Para cada coisa que é, ela, ao mesmo tempo, é gerada e consolidada, é todo e é parte, uma e múltipla, mesma e outra, movimento e repouso ${ }^{132}$. Tudo indica, portanto, que podemos dizer que, como o sofista e o político (alvos do método da divisão), o ser também é composto de contrários antitéticos, que se complementam compondo a sua unidade. Isto é justamente o que parece estar ocorrendo no caso dos gêneros supremos do Sofista, com os pares antitéticos movimento/repouso e mesmo/outro compondo a unidade de um outro gênero, a do ser. Diz Platão no Político:

“É preciso, quando alguém, anteriormente, perceber uma

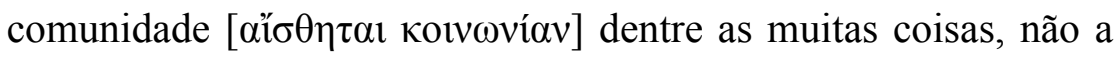
abandonar antes de ter enxergado ['íṇ], nesta comunidade, todas as

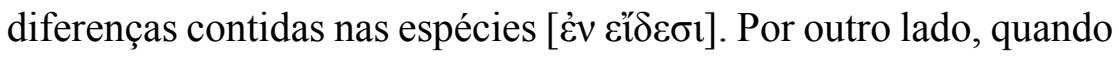
ver, na multiplicidade, todos os tipos de dessemelhanças, não se pode ser inconveniente e desistir antes de ter oferecido o conjunto

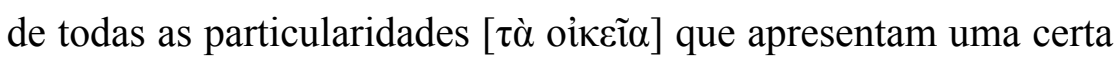

cada um dos termos da oposição parece ser uma relação antitética. Isto explicaria, por exemplo, que o ser seja considerado um e múltiplo: a respeito de cada uma das formas, seja múltiplo (256e6), mas, por outro lado, por si mesmo, seja um (257a5).

${ }^{131}$ Esta "extensão máxima" é tratada, por exemplo, no texto de Marcelo Pimenta Marques citado acima.

${ }^{132}$ No entanto, ainda não é claro para nós o motivo de Platão recusar a divisão daquele que vema-ser no Filebo (15a-b). 
semelhança e as ter reunido na essência [ov̉oíấ] de um certo gênero

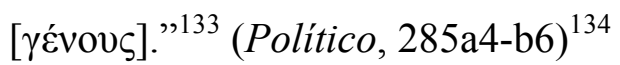

Assim, se seguirmos este comentário de Platão a respeito do método da divisão, dividir corretamente seria saber distinguir entre as semelhanças e as dessemelhanças,

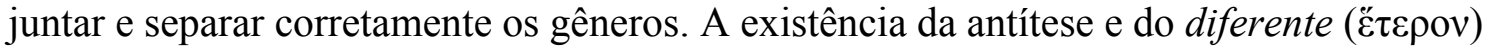
seria, portanto, aos olhos de Platão, condição necessária para dizermos com rigor que uns gêneros não participam de alguns gêneros, mas participam de outros. De fato, ao menos no contexto do Sofista, é esta diferença que possibilita o discurso falso, mas também é esta diferença que possibilita o discurso verdadeiro. Mas, ao nosso ver, a noção de

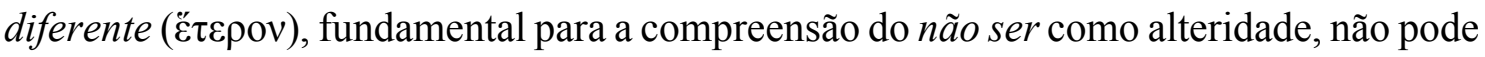
ser dissociada da noção de contraposição ( $\dot{\alpha} v \tau i ́ \theta \varepsilon \sigma 1 \varsigma)$. O diferente e a antítese fornecerão,

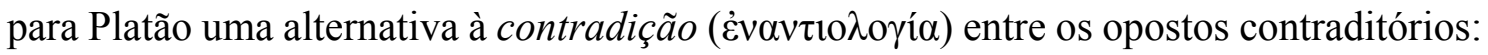

"Hóspede de Eleia: E não só demonstramos que as coisas que não

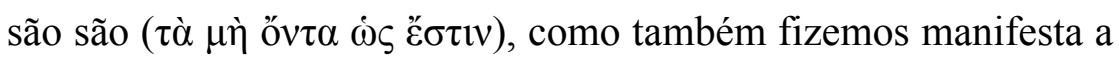
forma do não ser, que por acaso é, ao termos demonstrado que a

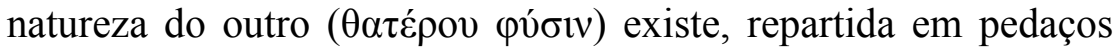
sobre todas as coisas que são, umas em relação às outras. E tivemos a ousadia de dizer que cada parte do outro, contraposta

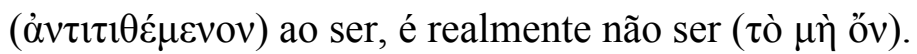

Teeteto: E parece-me, Hóspede, que dissemos muitas verdades.

Hóspede de Eleia: Pois bem, que alguém não nos diga que o não

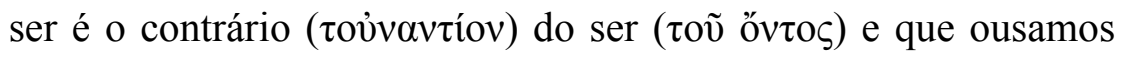
dizer que o não ser é."135 (Sofista, 258d5-258e7)

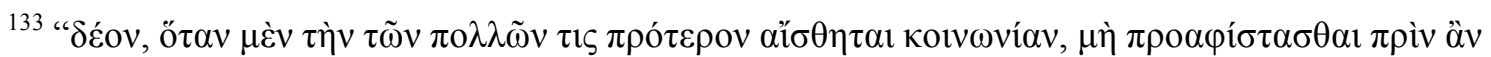

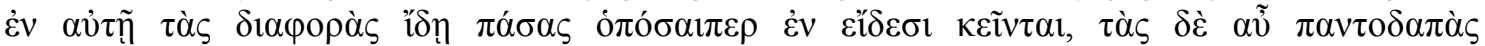

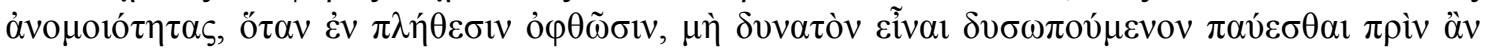

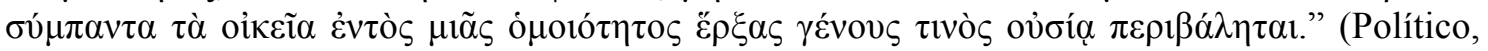
285a4-b6)

${ }^{134}$ Tradução nossa.

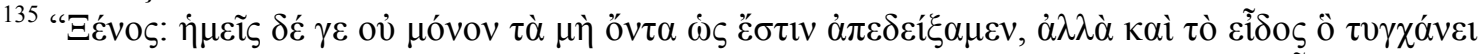

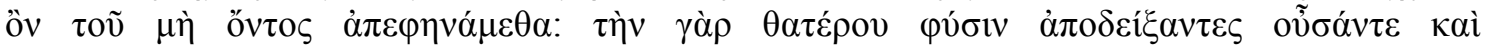

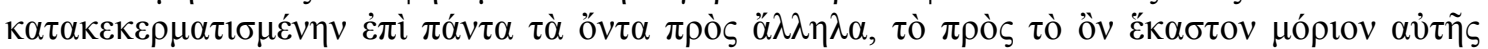

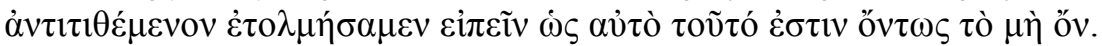

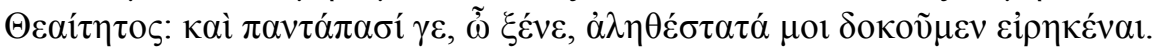


A natureza do diferente se apresenta em todos os gêneros, isto é todo gênero participa do diferente:

\begin{abstract}
"Logo, necessariamente o não ser é sobre o movimento e por todos

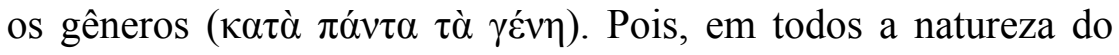

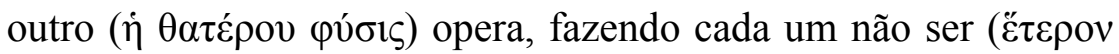

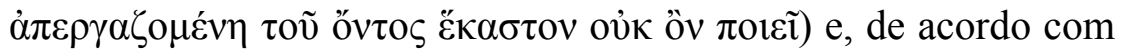
isto, diremos com correção que todas as coisas não são, e, de novo, por participarem do ser, que são e também que existem.",136 (Sofista, 256d11-e4)
\end{abstract}

Ao apresentar uma indistinção entre gênero e espécie na sua formulação, o método da diairesis parece, ao nosso ver, pressupor o fim da separação estanque entre o que chamaríamos, grosso modo, de sensível e de inteligível. Desta maneira, este caminho dialético teria como objetivo operar a passagem entre os gêneros menores e os gêneros maiores, encadeando-os com a pretensão de elencar todos os seus intermediários.

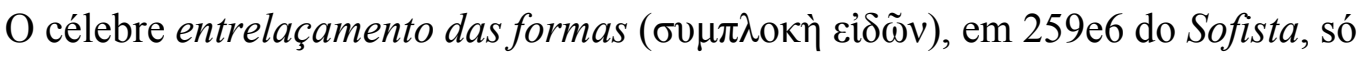
parece ser possível neste novo contexto em que as ideias não são em si e completamente

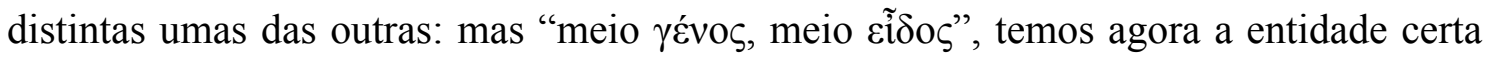
para encadear um discurso articulado e não monolítico. Não podemos esquecer que, no que diz respeito à unidade do discurso, esta também será formada pela contraposição de dois termos que parecem ser opostos: nomes e verbos (Sofista, 261e e seguintes).

É justamente de todo este complicado imbróglio ontológico que Gilbert Ryle pretende fugir ao propor que a dialética do Sofista de Platão deveria ser lida a partir da analogia entre as letras e as sílabas (RYLE, 2009 [1960], pp. 57-75): de fato, tal analogia é recorrente no corpus platônico ${ }^{137}$. Ao compreender que o fonema de uma sílaba é o

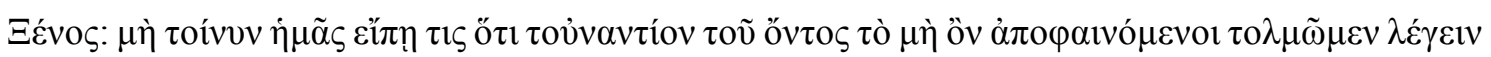

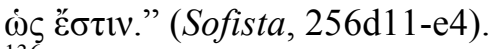

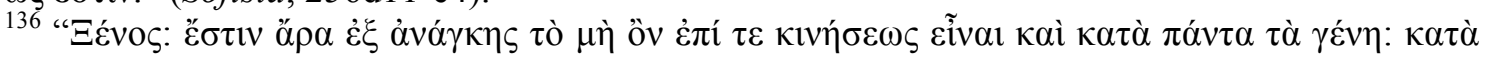

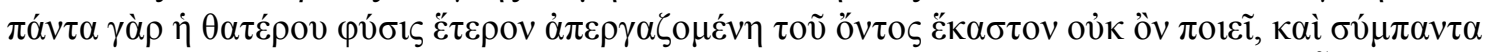

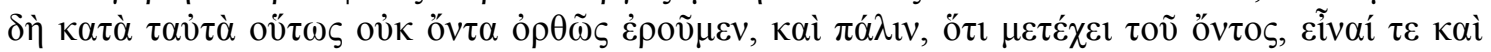

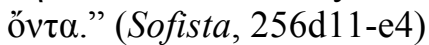

${ }^{137}$ A analogia aparece, por exemplo, no Sofista (253a), no Teeteto (202e), no Político (277e278d), no Filebo (17a-b) e no Crátilo (426c-427c). 
elemento primordial do som emitido, anterior às vogais e consoantes que o compõem (afinal, precisamos utilizar as vogais para emitir o som das consoantes), Ryle pretendia mostrar que, assim como na relação entre letras e sílabas, um enunciado era também predominante sobre as partes que o constituem (para o caso platônico, mais fundamental que os nomes e os verbos que o compõem). Para assumir tal posição, arcou com o ônus de descartar a importância do método da divisão.

Em seu artigo Plato's Parmenides (RYLE, 2009, [1939], pp. 1-46), Ryle apontou 5 argumentos que seriam suficientes para não levar a sério o método da divisão (RYLE, 2009, p. 43):

(i) Pois ele se baseia em conceitos de "gênero" e "espécie" e "determinado" e "indeterminado", o que não é base para problemas filosóficos;

(ii) Porque nem sempre temos uma oposição entre duas espécies;

(iii) Pois o resultado da divisão pode ser desmentido por pesquisas empíricas;

(iv) Que há certa arbitrariedade no método dialético da divisão;

(v) Devido ao resultado das definições obtidas por ele terem como resultado algo indeterminado.

De certo modo, tratamos da maioria deste argumentos ao longo dessa nossa exposição. Assim, como já havia sido apontado por Akcrill em um importante artigo de 1970 (ACKRILL, 1970, p. 373-392), Ryle parecia estar completamente enganado ao

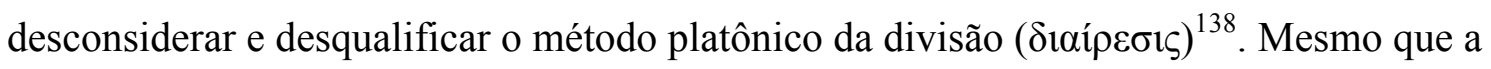
aplicação do método contenha indiscutíveis imperfeições e a sua formulação, de fato, seja

\footnotetext{
${ }^{138}$ Esta também é a posição de Antonia Soulez: "Pour cette raison, je dirais qu'il y a division et division et que le non-être comme Autre, cause stable de la division entre genres, laisse entrevoir une 'espècie' de division à laquelle Ryle semble n'avoir pas du tout songé: une division proprement dialectique qui fait um avec la recension logique des Formes dont les énoncés forment système, une diaíresis sans images, à laquelle ne repugne pas la méthode dia tôn logôn (253b8) qui revient au dialecticien d'après le Sophiste.

C'est dire qu'en privilégiant excessivamente la fonction opératoire de la négation à l'encontre de la procédure de la division par espèces et par genres comme si cette division était tout ela division, G. Ryle a finalement sous-estimé, avec la fonction stable du non-être, l'aspect non pas 'formel' mais je dirais 'onto-formel' du projet catégorial de Platon. La vraie raison moins aparente du sacrifice rylien de la division ne serait-elle pas que cette division des genres em espèces ne parle plus au philosophe analytique d'aujourd'hui, plutôt que la mise entre parenthèses de la prédication ordinaire sous pretexte que'elle est logiquement inintéressante aus yeux de Platon lui-même?" (SOULEZ, 1991, pp. 232-233). Os itálicos no texto são da própria autora.
} 
bem obscura, ao nosso ver, devemos lê-lo com o propósito de identificar sua consistência com as novas posições ontológicas apresentadas no diálogo.

De maneira nenhuma a intenção deste nosso texto seria a de defender uma simples prevalência ontológica sobre as práticas discursivas. Pensamos apenas que, no contexto da obra platônica, os movimentos ontológicos e discursivos devam ser considerados em conjunto: haveria neste caso um forte isomorfismo entre o discurso e ontologia, isto é, as mudanças no posicionamento ontológico vieram acompanhadas de uma inovação dialética. Pensamos que as mudanças ontológicas no tratamento das "ideias", que agora não aparecem ser mais completamente em si e nem distintas das outras, parece ter uma correlação com o novo procedimento dialético que prevalece nos diálogos tardios.

Em um célebre momento de seu livro Plato's Progress, Ryle diz que o Sofista se assemelha a um sandwich: uma parte central de elaborados raciocínios filosóficos envolto por operações de divisão nada sofisticadas (RYLE, 1966, pp. 139-140). Digamos, então, do seguinte modo: ao propor uma visão unitária e consistente do diálogo, não buscamos desfazer das evidentes qualidades da leitura de Ryle, pretendemos apenas começar a harmonizar aquele sandwich que, apesar do delicioso recheio, infelizmente oferecia a nosso paladar um pão exageradamente insosso e frio. 


\section{A TESSITURA DO SER}

No que tange à riqueza das interpretações do Sofista de Platão, o século XX da era cristã pode ser considerado especialmente prolífico. Grande parte deste interesse, principalmente o da tradição anglo-saxã, parece ser explicado pela filosofia da linguagem que pode ser identificada por detrás das falas do Estrangeiro de Eleia realizadas mais ao final do diálogo. De fato, entre 259d9-264b9 do Sofista, o Estrangeiro aplica suas posições ontológicas ao discurso e à opinião. Este avanço em direção às formas discursivas completará o excurso ontológico, fornecerá um encerramento a ele e nos permitirá retornar às divisões propriamente ditas que buscavam definir o sofista.

$\mathrm{Na}$ esteira de Russell e de Wittgenstein, inúmeros comentadores enxergaram que estas páginas de Platão apareciam como precursoras de conceitos proposicionais modernos tais como forma lógica, bivalência ou a distinção entre o sentido e a veracidade de uma proposição. É certo que tais comparações parecem ser justificadas e acertadas. No entanto, se, como vimos no segundo capítulo deste trabalho, identificávamos nos gêneros supremos o funcionamento do mecanismo antitético (tido como de separação e conjunção entre os gêneros), agora, no caso dos discursos, a situação não parece ser diferente.

A título de exemplo, podemos notar que o filósofo inglês Gilbert Ryle viu no texto platônico mais do que uma prefiguração da teoria dos tipos de Russell (RYLE, 2009 [1939], p. 19, 22, 33-34, 37; RYLE, 2009 [1960], p. 70-71), ao que tudo indica via o início de uma linhagem filosófica que passaria antes pelas categorias de Aristóteles para desembocar na filosofia de Wittgenstein. Deste modo, o filósofo de Oxford não deixou de marcar, por meio da analogia platônica com a técnica de juntar letras e sílabas numa palavra, a prevalência do enunciado sobre as partes constituintes de um discurso (RYLE, 2009 [1960]). Tal posição levava Ryle a interpretar cada um dos gêneros supremos como classes ou tipos proto-categoriais de elementos discursivos, isto é, eles marcariam os modos de relação entre os termos que comporiam um enunciado significativo. No entanto, aparentemente, tal posicionamento ryleano tinha como ônus dar de ombros ao debate em 
torno da dialética da divisão e do debate platônico a respeito do eleatismo que pautavam o diálogo.

Portanto, o intuito deste presente capítulo será associar o trabalho antitético da dialética platônica do Sofista à fundamentação da forma básica de um enunciado que seja significativo e digno de receber o valor de "verdadeiro" ou "falso". Esta intrincada tarefa ontológico-discursiva não só proporcionará uma finalização para a questão em torno da aporia eleática, mas também possibilitará que o Estrangeiro nos forneça sua derradeira definição de sofista. Afinal de contas, será apenas por meio de uma nova abordagem da filosofia de Parmênides que ficará possível capturar aquele sofista que havia se refugiado na aporia eleática do não ser (Sofista, 236d1-3/239c4-7/254a4-6).

No entanto, de princípio, é possível notar que os comentadores não costumam associar a divisão platônica, e nem a oposição antitética, àquela conjunção entre nomes e verbos que é apresentada, pelo Estrangeiro, como elemento fundamental para a construção de um enunciado significativo. Na maioria das vezes os comentadores não articulam as considerações finais a respeito da dialética (que começam em 253d) com as questões relativas ao discurso. Julius Moravcsik, estudioso da obra platônica, aparece como uma espécie de excessão, e não deixa de colecionar críticas por conta de seus posicionamentos.

Fato é que, logo após tratar dos gêneros supremos e da dialética, o Estrangeiro, imediatamente, dirige sua investigação para o gênero do discurso:

"Avancemos com vista a estabelecer para nós o enunciado ( $\lambda$ óyov) como um dentre os gêneros ( $\gamma \varepsilon v \tilde{\omega} v)$. Pois, privados dele, ficaríamos privados da filosofia, que é o mais importante, e mais, é preciso que cheguemos agora a acordo

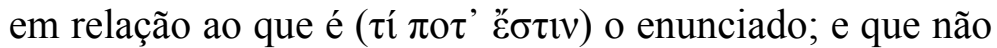
seríamos capazes de dizer coisa nenhuma de decidíssemos que não é absolutamente nada; e que seríamos privados dele se concordássemos que não há em nada mistura nenhuma

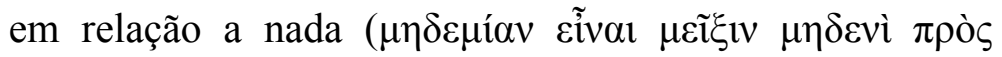
$\mu \eta \delta \varepsilon ́ v) . " 139$ (Sofista, 260a5-b2)

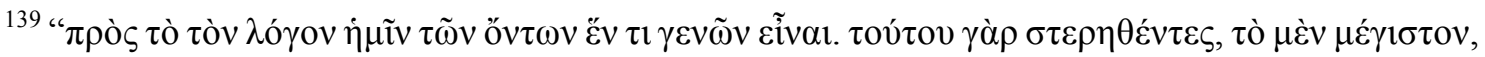

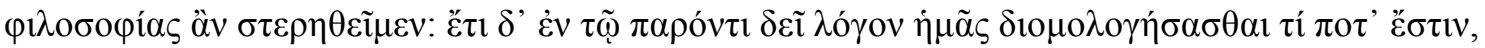


Fica claro, com esta passagem, que o que está em curso é uma aplicação ao discurso e à opinião dos resultados atingidos pela investigação anterior, a saber, a nova compreensão da noção de não ser e da possibilidade de mistura entre os seres. O trabalho bruto e mais difícil já aparece ter sido feito pelo Estrangeiro, agora bastaria direcioná-lo para o discurso e para a opinião (Sofista, 260b10-c4). Deste modo, para Platão, dois seriam os argumentos do sofista (260c11-261a4) que teriam de ser contornados: (i) posto que não participa do ser, o não ser não pode ser dito; e (ii) mesmo que o não ser, de algum modo, participasse de algumas formas e do ser, poderia não participar do gênero discursivo e, portanto, deste modo, não seria possível existir discursos falsos. Como conclusão de cada um desses argumentos, o sofista, segundo o Estrangeiro de Eleia, dizia não existir arte de produzir imagens ou arte do simulacro. Então, posto que o Estrangeiro ofereceu uma saída para a primeira aporia, caberia a ele, agora, direcionar a resolução alcançada para este segundo argumento que poderia ser utilizado pelos mestres da retórica.

O Estrangeiro, portanto, prossegue em sua argumentação. Assim, posto que, pelo fato de realizarmos discursos, o discurso existe. O discurso não existiria se nenhuma coisa se misturasse com outra (259e4-6): se todas as coisas fossem completamente disjuntas entre si, não haveria possibilidade sequer de existência da filosofia. Logo, se existe mistura em algo (e existe, como já foi dito anteriormente), é possível que haja mistura também no discurso, assim o discurso também pode ser considerado um gênero ( $\gamma \varepsilon v \eta ́)$. Poderá carregar também em si a marca do não ser (260b7-8), a partir de agora comprendido como alteridade. Cabe saber o modo exato com que o resultado alcançado pelo Estrangeiro se aplicaria ao contexto discursivo como um todo. Somente assim, estará garantido não só a existência do discurso falso, ou seja, ser possível dizer aquilo que, de algum modo, não é (260c1-4), mas também a existência de discursos verdadeiros. Como já havia sido indicado por Platão, assim como a primeira aporia do diálogo estava relacionada com a segunda, também o discurso verdadeiro estaria relacionado ao seu oposto, sendo complementar ao discurso falso.

Em 263b, Platão nos oferece sua aparente definição de discurso verdadeiro e de

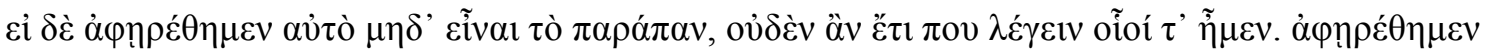

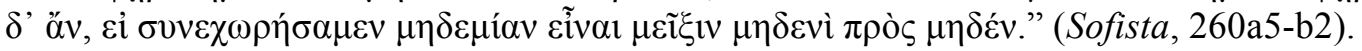


discurso falso:

"Hóspede de Eleia: E, desses aí, devemos dizer que cada um dos dois é de certa qualidade ( $\pi$ oĩóv)?

Teeteto: Que um é falso ( $\psi \varepsilon v \delta \tilde{\eta})$ e o outro é verdadeiro $(\dot{\alpha} \lambda \eta \theta \tilde{\eta})$.

H: Deles, o verdadeiro, diz a teu respeito as coisas que são

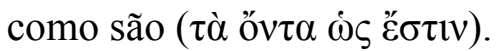

T: Mas, como?

H: E o falso diz coisas diferentes das que são (๕̌ $\tau \varepsilon \rho \alpha \tau \tilde{\omega} \nu$ őv $\tau \omega v)$.

$\mathrm{T}: \operatorname{Sim}$.

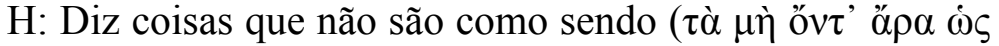

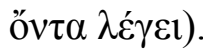

T: Mais ou menos.

H: Das coisas que são, que são outras a respeito de ti ( $\check{\varepsilon} \tau \varepsilon \rho \alpha$ $\pi \varepsilon \rho i ̀ ~ \sigma o \tilde{)}$. Pois dissemos que, acerca de cada um, muitas coisas são e muitas não são" ${ }^{\text {140 }}$ (Sofista, 263b2-12)

O discurso, portanto, seja ele verdadeiro ou falso, sempre pretende dizer aquilo que é: quando acerta e diz que as coisas são como se é, temos o discurso verdadeiro;

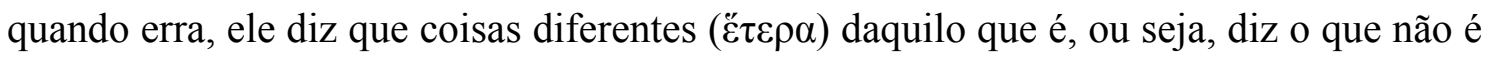
e, portanto, deve ser identificado com um discurso falso. Não poderíamos deixar de reparar que as noções de verdade e falsidade se dão, neste momento do Sofista de Platão, sempre por referência ao ser e ao não ser. Ou seja, mesmo que a noção de não ser assuma

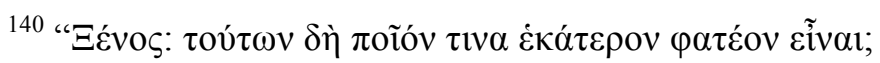

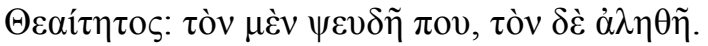

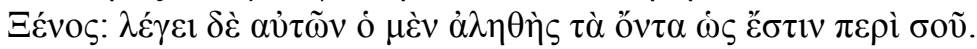

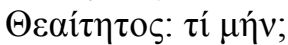

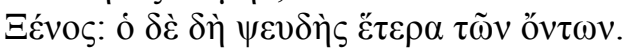

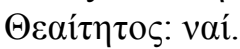

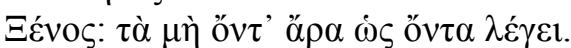

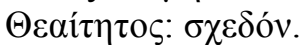

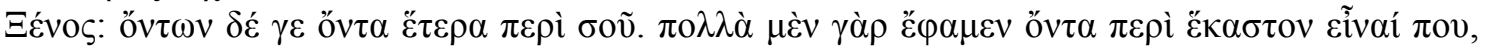

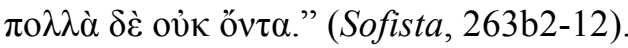


uma nova forma, não eleática, ao ser tomada como alteridade, o critério para algo distinguirmos algo verdadeiro de algo falso ainda permanence vinculado ao Poema de Parmênides (no qual o caminho da verdade se pautava pela referência no ser) ${ }^{141}$.

Entretanto, não poderíamos chegar numa completa compreensão do discurso verdadeiro ou falso sem antes estabelecer a forma correta do enunciado que possibilitará que ele participe ou não participle do ser. Se o discurso é acima de tudo um tipo de entrelaçamento entre formas, precisaríamos identificar quais são os elementos que devem ser, fundamentalmente, articulados pelo discurso. Para dizer em outros termos, precisamos encontrar a forma lógica de um enunciado que possa ser bivalorado. Diz, então, Platão:

\begin{abstract}
"Pois ele mostra já algo a respeito das coisas que são, ou que vêm a ser, ou que vieram a ser, ou que virão a ser, mas conclui algo, combinando os verbos com os nomes

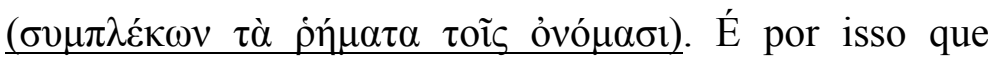
afirmamos que está a dizer ( $\lambda \dot{\varepsilon} \gamma \varepsilon ı v)$ e não somente a nomear

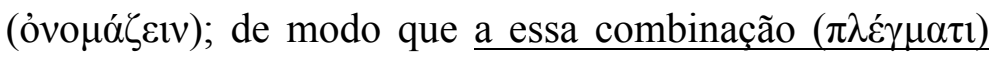

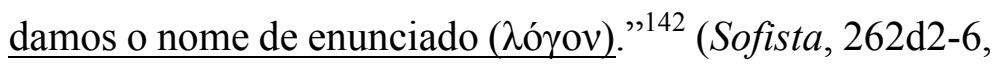
o grifo é nosso)
\end{abstract}

Esta será a forma proposicional: um discurso é aquilo que é formado pelo entrelaçamento de nomes e verbos. A nomeação de algo seria, portanto, condição necessária mas não suficiente para o estabelecimento de um discurso. Para que algo seja considerado discurso, não basta que atribuamos um nome a algo: doravante devemos definir o discurso como uma espécie de articulação. Isto é, a partir de agora, a significação de um termo não poderá mais ser confundida com a veracidade do discurso. Precisamos

\footnotetext{
${ }^{141}$ A vinculação deste trecho da obra platônica com o Poema de Parmênides pode mesmo ser indicada por um pequeno detalhe que pode ser indício da referência textual: Platão, tanto na definição do discurso verdadeiro como no do falso se utiliza do " $\dot{\iota} \varsigma$ " (Sofista, 263b4/263b9) do mesmo modo como Parmênides o utilizou (e que gera até hoje tantos problemas e discussão entre os estudiosos do tema) no fragmento 2 do Poema (Parmênides, DK B 2, 3/2, 5).

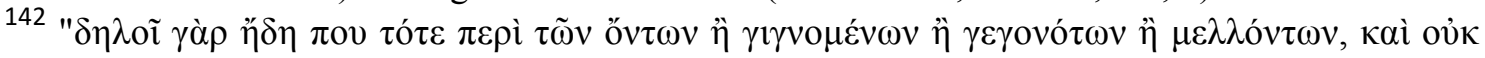

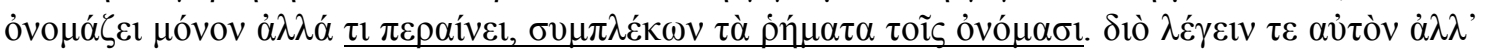

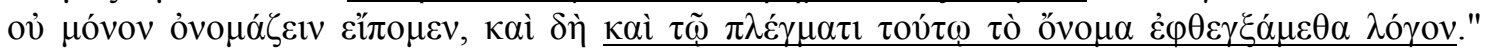
("Sofista", 262d2-6, o grifo é nosso)
} 
sim atribuir um nome para cada coisa, no entanto seá somente ao associá-lo a outro termo (um verbo) que obteremos a possibilidade de conferir uma qualidade ou um valor ao discurso. Vale esclarecer, todavia, que este procedimento platônico com relação ao discurso não pretende dizer quais são os discursos verdaddeiros e quais são os discursos falsos (para o que precisaríamos de uma espécie de epistemologia), mas apenas garante que existem discursos verdadeiros e falsos estabelecendo uma condição formal para suas existências (uma tarefa que chamaríamos, portanto, de lógica).

No Sofista, Platão nos oferece, então, três exemplos modelares deste discurso em

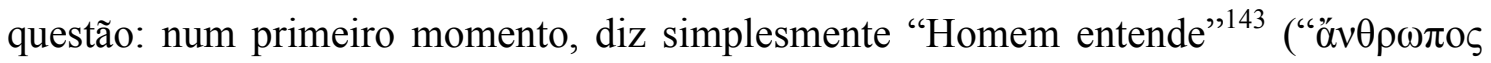
$\mu \alpha v \theta \alpha ́ v \varepsilon ı "$, em 262c9). Na sequência oferece os dois tipos de discursos que apresentam qualidades diferentes:

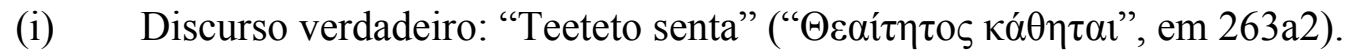

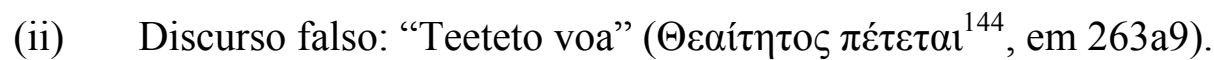

Mais importante é notar que, em todos os exemplos, a forma mínima do discurso é composta exatamente pela conjunção de um nome e um verbo: segundo Platão, este seria o primeiro e menor dentre enunciados (262c6-7), ou seja, a condição mínima para que algo possa ser considerado discurso. A forma do enunciado é descrita por Platão do seguinte modo:

"Hóspede de Eleia: (...) com efeito, para nós são dois os gêneros de coisas ditas pela voz acerca da entidade ( $\pi \varepsilon \rho \grave{~}$

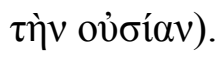

Teeteto: Como?

H: Os gêneros dos chamados nomes (ỏvó $\mu \alpha \tau \alpha)$ e dos verbos $(\dot{\rho} \eta \dot{\mu} \alpha \tau)$.

T: Diz cada um dos dois.

\footnotetext{
${ }^{143}$ Apesar do tempo presente do verbo grego costumar indicar algo como "o homem está aprendendo", "Teeteto está sentado" ou "Teeteto está voando", nossa tradução buscou valorizar, formalmente, a simples conjunção dos dois elementos básicos do discurso para Platão: o nome e o verbo.

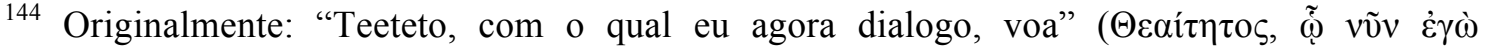
$\delta 1 \alpha \lambda \varepsilon ́ \gamma o \mu \alpha 1, \pi \dot{\varepsilon} \tau \varepsilon \tau \alpha l)$, em 263a9.
} 
H: Chamamos verbo ( $\dot{\eta} \tilde{\mu} \alpha$ ) ao que se mostra na ação $(\pi \rho \alpha ́ \xi \varepsilon \sigma \mathrm{v})$.

T: Sim.

$\mathrm{H}$ : E chamamos nome ao signo da voz posto naqueles mesmos que praticam as acções.

T: Perfeitamente; é isso.

H: Portanto, ao dizer nomes em sequência, não obtemos jamais um enunciado, nem, por sua vez, dizendo verbos, separados de nomes." ${ }^{\prime 145}$ (Sofista, 261 e4-262a11)

No entanto, seria de grande vantagem recuar no texto e recordar qual era o primeiro objetivo do diálogo. Ao tratar da distinção ou indistinção entre o sofista, o político e o filósofo, poderemos lembrar que o método da divisão era o principal meio para lograr uma solução. Mas, podemos notar que o procedimento da divisão visava garantir que associaríamos ou não um tipo de gênero a cada nome que possuíamos de antemão:

"mas, primeiro, parece que deves começar agora por examinar em comum comigo acerca do sofista, buscando

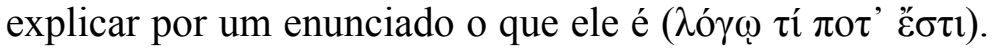
Pois, até agora, em comum, tu e eu temos acerca dele apenas o nome; mas a função ("̌prov) que lhe atribuímos será particular a cada um de nós. É preciso sempre, acerca de tudo, estar de acordo sobre o próprio facto $(\pi \rho \tilde{\alpha} \gamma \mu \alpha)$ mais pelo enunciado ( $\delta$ ̀̀ $\lambda \hat{\gamma} \gamma \omega v)$ do que pelo próprio nome

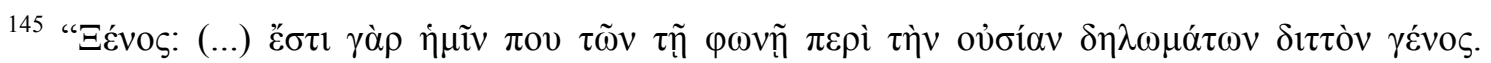

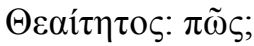

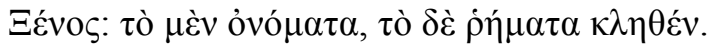

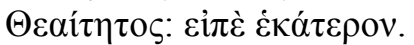

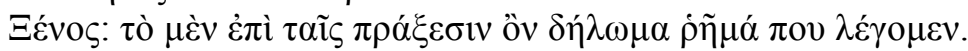

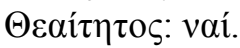

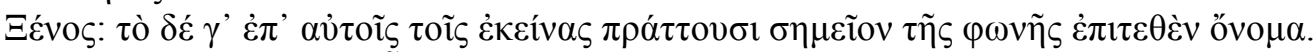

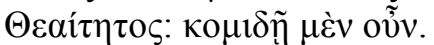

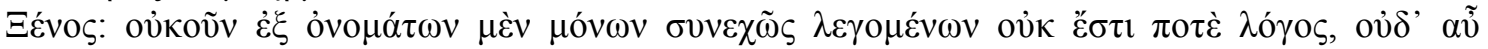

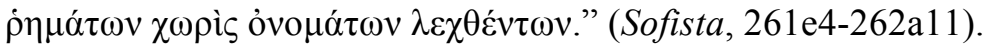




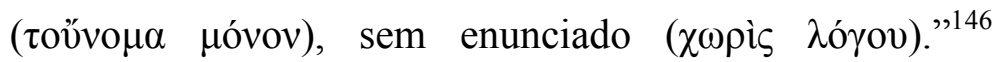
(Sofista, 218b7-c5)

E também, um pouco mais a frente:

"Então, chegamos agora a um acordo acerca da pesca à

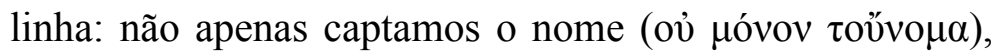
mas também a definição ( $\lambda$ óyov) bastante própria da acção

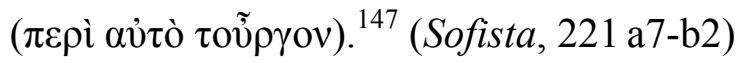

O que parece estar em questão aqui é a relação entre o nome e a ação praticada

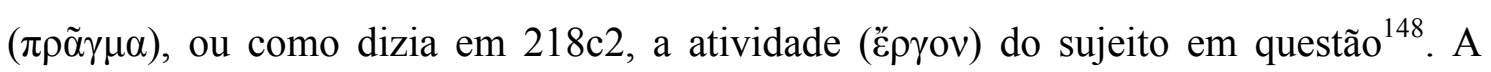
realização de um discurso significativo, verdadeiro ou falso, seria, então, cumprir exatamente o mesmo objetivo que o início do diálogo apontava: temos três nomes "sofista", "político" e "filósofo", teríamos também três atividades a eles associadas? Ali, no começo do diálogo, poderíamos dizer, já estava posta, mesmo que implicitamente, a questão da forma lógica do discurso.

Deste modo, não seria absurso afirmar que o o método da divisão estaria intimamente relacionado ao modo como deveríamos articular um enunciado significativo. O procedimento de dividir um gênero em suas partes apresenta a mesma estrutura de um discurso significativo, ou, para dizermos melhor, o processo divisivo seria a própria construção do discurso significativo. Quando realizamos o processo corretamente, podemos identificar com clareza se o gênero inferior está ou não contido num superior: se dissermos algo de acordo com a cadeia dos gêneros, proferimos um discurso verdadeiro; se dissermos algo diferente da cadeia dos gêneros, proferimos um discurso falso. Assim, ao dizermos, por exemplo, a frase "O sofista produz imagens" poderíamos

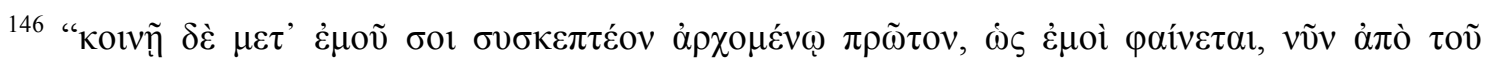

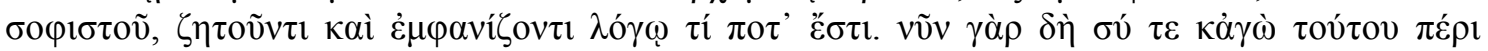

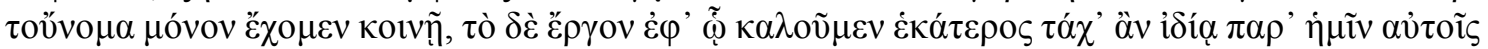

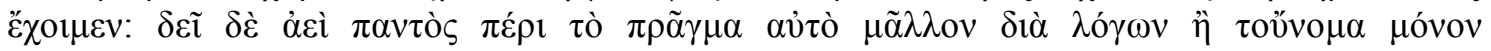

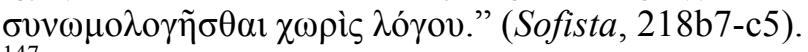

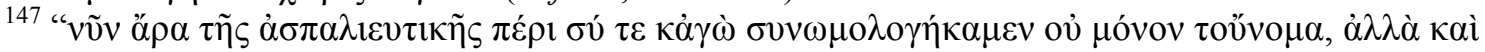

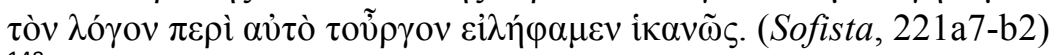

${ }^{148}$ Ao que parece, no contexto do Sofista de Platão, atividade (ergon) e ação (pragma) são sinônimos.
} 
identificá-la como verdadeira apenas se o gênero "sofista" participasse do, ou se misturasse com o, gênero da "arte de produzir imagens".

Mas de que modo os chamados gêneros supremos se relacionariam com o discurso? O que a oposição antitética poderia acrescentar à compreensão do discurso? Acreditamos que, posto que gêneros supremos se mostram como gêneros superiores na cadeia do ser, que vai do múltiplo ao um e do um ao múltiplo, estes parecem exercer, portanto, uma certa relação como os gêneros inferiores: significa que os gêneros mais inferiores, que estiverem sob o escopo dos superiores, estariam como que regidos pelos gêneros mais altos. Tal relação poderia estar próxima daquela entre um modelo e sua imagem, no entanto a passagem é gradual, por meio de um ou mais intermediários (no caso dos gêneros supremos, provavelmente, por muitos intermediários).

Deste modo, o discurso, um gênero inferior aos gêneros supremos, por estar regido pelos gêneros mais altos, deve ter um funcionamento semelhante aquele dos gêneros supremos, isto é, funcionará com base nas relações antitéticas da dialética, relação antitética, agora, baseada na união entre nomes e verbos. Poderíamos dizer que, de certa forma, o nome e o verbo de um discurso remeteriam ao modelo antitético que se apresentava nos gêneros supremos. Nomes e verbos seriam então como que figurinos nos quais dois gêneros entrariam para que um discurso pudesse ser enunciado. Para evitar confusões, poderíamos dizer que o enunciado "O sofista produz" (conjução de um nome e um verbo) diz a mesma coisa que "O sofista é produtor" ou "O sofista participa da arte da produção". Ou seja, o verbo não é nada mais do que a contração da copula "é", ou da noção de participação, a uma outra forma ou gênero: "nome + verbo" é, portanto, ao nosso ver, o mesmo que "X é Y" ou "X participa de Y".

Dizer um discurso verdadeiro significa atribuir as ligações devidas entre os gêneros, ou atribuir a falta de ligação entre eles (o que significa a cópia da estrutura do ser). O falso seria fazer o inverso, atribuir mistura quando não há e não misturar quando a mistura é presente na cadeia dos seres. Assim, Platão estaria instituindo no diálogo Sofista um novo modo de compreender o erro, completamente diferente daquele modo encontrado no diálogo Teeteto (tomar, por exemplo, Teeteto por Teodoro, Teeteto 199ab) e bem diferente do "dizer outra coisa" de Antístenes: ambos erros relacionados, de algum modo, à má nomeação. Com o trabalho realizado pelo Estrangeiro, errar é não capturar a harmonia da articulação que está estabelecida entre as formas ou os gêneros. 
É importante notar que, mesmo que diga atentar contra Parmênides, Platão, por meio do Estrangeiro, não deixa de aceitar duas importantes teses eleáticas contidas no Poema do mestre de Eleia: (i) que o ser deve ser tomado como critério de verdade; e (ii) que é possível, de algum modo pensar, e no caso platônico, dizer o ser. Este último conhecido como postulado da inteligibilidade do ser, apresentado por Diels-Kranz como fragmento III do Poema.

Então, parece-nos que Platão no intuito de garantir a inteligibilidade do ser (pois o pensar é o discurso mudo proferido da alma consigo mesma ${ }^{149}$ ) modifica a interpretação deste "mesmo" ( $\alpha$ ủंò) do fragmento III de Parmênides. Se Parmênides parecia entender este "mesmo" como "uma única e mesma coisa", como identidade, Platão parece passar a afirmar que algo é discurso somente quando apresenta, formalmente, a "mesma estrutura" do ser. Para ser verdadeiro tal discurso terá que, adicionalmente, articular corretamente os conteúdos de tal estrutura formal. Assim, no caso de Platão, o discurso poderia ser visto como uma espécie de arqueiro que, apesar de sempre buscar atingir o alvo, às vezes o acerta e às vezes o erra.

Este processo de elucidação da forma discursiva, proporcionado pelo Estrangeiro de Eleia, no entanto, se revela em 264c, no interior da divisão da arte de produzir imagens

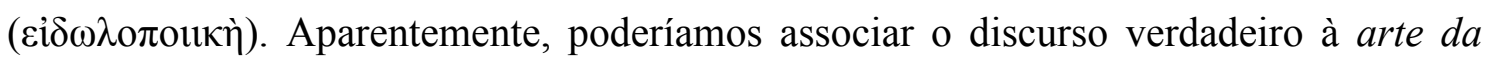

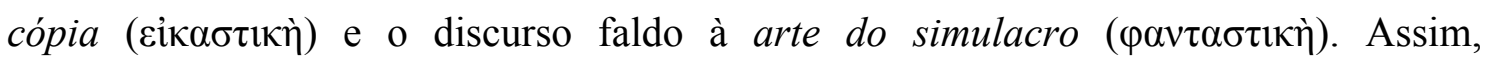
poderíamos dizer que, como para o Wittgenstein do Tractatus Logico-Philosophicus, o discurso se-dá sempre, para Platão, como imagem ou figuração de algo: o termo "Bild" para Wittgenstein estaria como o termo $\varepsilon \Uparrow \delta \omega \lambda o v$ para Platão.

Cabe notar ainda que as primeiras seis definições não são suficientes para capturar o sofista, que insiste em se esconder no "refúgio inextrincável do não ser". Para conseguir capturá-lo, Platão teve de trilhar a vereda do não ser, que havia sido proibida pelo édito

\footnotetext{
149 "Hóspede de Eleia: Pois bem, pensamento e discurso são o mesmo; mas o primeiro, que é o diálogo íntimo da alma consigo mesma, que nasce sem voz, é esse mesmo que foi por nós denominado pensamento?"

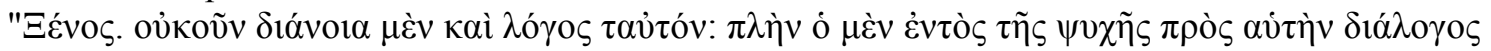

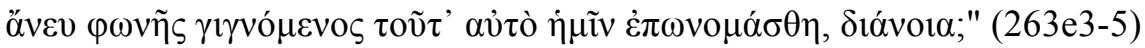


de Parmênides.

Mesmo que boa parte dos conteúdos das sete definições de sofista já pudessem ser encontrados em passagens de obras precedentes ao Sofista, é possível ver que, especialmente a sétima definição, não cumpre as exigências tradicionais para uma definição, pelo menos tal como elas foram expostas no "Êutifron" ${ }^{150}$. Isto se deve ao fato de que tanto o sofista quanto seu discurso sempre devem ter a capacidade de ter em si um

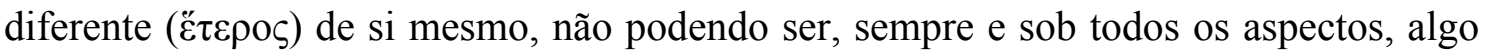
identitário ( $\tau \alpha$ خóv). Do mesmo modo, estas feições, ou idéias, neste caso, não podem ser completamente irredutíveis entre si e, de algum modo, podem conter aquilo que não são, para resolver este impasse, foi criada a noção de "entrelaçamento das ideias" ( $\sigma 0 \mu \pi \lambda$ okì

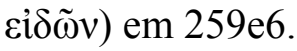

Notemos que há certa correspondência entre a condição ontológica dos discursos do sofista e a própria figura do sofista: ambos aparecem sem ser (como a primeira aporia se construía a partir de 236b). Tudo parece indicar que tanto este enunciador quanto seu enunciado: são uma "má mimese" de algo, entretanto este algo, que seria modelo para o discurso e para aquele que discursa, não é completamente claro no diálogo. Isto pode ser entrevisto na seguinte passagem, que está buscando a última definição do sofista:

"Teeteto - Dizer que é sábio [бo甲òv] é impossível, porque o colocamos como não conhecedor, mas, porque é imitador do sábio

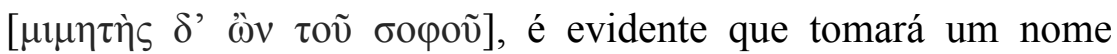
paralelo ao dele, e agora já quase entendi que é preciso nomear verdadeiramente aquele que por completo é realmente um sofista

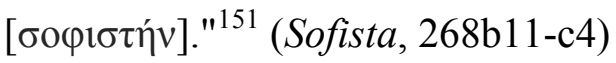

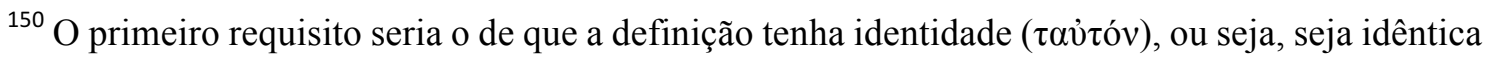
a si mesma em todos os casos. Podemos dizer, também, que seu contrário (غ̇vavtíov), também idêntico a si mesmo, tem de se mostrar completamente disjunto do contrário correspondente: por exemplo, não poderia, neste caso, em nenhuma hipótese, juntarmos o piedoso e o ímpio (a presença de um exclui a do outro). Por outro lado, podemos notar que a definição do piedoso, para ser adequada, deve abarcar todos os casos particulares nos quais se identificam ações piedosas (Platão, Êtifron, 5d1-5 e 6d9-e7).

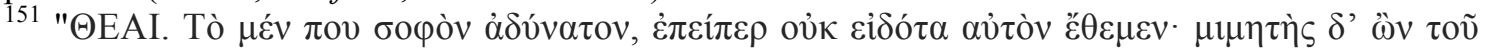

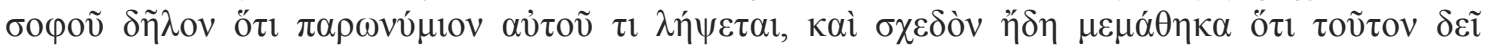

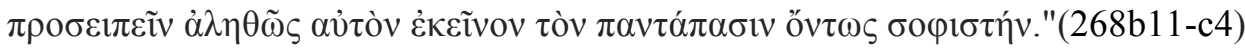


Assim, por não ser o "sábio" (бoழóৎ), o sofista leva o nome de "sofista" ( $\sigma 0 \varphi ı \tau \tau$ $\varsigma)$, aquele que está é ou produz o simulacro ( $\varphi \alpha ́ v \tau \alpha \sigma \mu \alpha)$. Deste modo, ao sofista cabe produzir imagens ruins ou realizar uma má mimese. Da mesma maneira, caberia perguntar: porque, então, haveria o filósofo de carregar o pudor de "amigo" impresso em seu nome? Talvez a condição intermediária do filósofo, assim como a do sofista, também possa ser explicada pela noção de mimese, mas, neste caso, boa mimese.

O platonismo, portanto, ao realizar a tarefa de instituir uma boa imagem, e talvez, também uma boa mimese, parece pretender matar seu pai para que a filosofia deste continue viva, ou seja, para impedir que a implosão sofística das teses de Parmênides faça com que o eleatismo sucumba aos interesses dos mestres da retórica e da ilusão.

Ao que parece, como vimos no primeiro capítulo, Górgias de Leontinos, a partir também da filosofia eleática, via uma indistinção entre o verdadeiro e o falso, entre a boa imagem e a má imagem. O diálogo Sofista, portanto, parece disputar a interpretação sobre o Poema de Parmênides, nos fornecendo um antídoto às posições sofísticas: uma disputa filosófica que, de certo modo, também já era um protótipo de história da filosofia.

Se, como era na escatologia final do seu diálogo Fédon aos parricidas estava reservado queimar permanentemente no rio de fogo do Tártaro, a espera do perdão daqueles de suas vítimas (Fédon, 113e-114a), Platão, por sua vez, não parece, pelo trato conferido à filosofia do pai Parmênides, merecer tamanha punição. Do mesmo modo, apesar de todos os nossos esforços, talvez, para todos nós, herdeiros e parricidas da tradição filosófica, a interpretação definitiva da filosofia platônica de fato não exista e, assim, Platão deva continuar permanentemente no lugar onde Dante Alighieri ${ }^{152}$ uma vez o deixou: num eterno e bem frequentado limbo.

${ }^{152}$ Divina Comédia, Inferno, Canto IV. 


\section{BIBLIOGRAFIA}

ACKRILL, J. L. In defense of platonic division, in Ryle, edited by Oscar Wood and George Pitcher, Macmillan and Co.,1970, pp. 373-392.

ALLINE, Henri. Histoire du texte de Platon, Slatkine/Champion, Genève/Paris, 1984.

ARISTÓTELES. Da interpretação, tradução de José Veríssimo Teixeira da Matta, Ed. UNESP, São Paulo, 2013.

. Física: livros I e II, tradução, introdução e notas por Lucas Angioni, Ed. UNICAMP, Campinas, 2009.

. Metafísica: livros VII e VIII, in Clássicos da Filosofia: cadernos de tradução $n^{\circ} 11$, tradução, introdução e notas por Lucas Angioni, UNICAMP/IFCH, Campinas, 2005.

AUBENQUE, Pierre. L'histoire de la philosophie est-elle ou non philosophique? Oui et non, in Nos Grecs et leurs Modernes: les stratégies contemporaines d'appropriation de l'antiguité, Éditions du Seuil, 1992, pp. 17-36.

. O problema do ser em Aristóteles, Tradução e revisão técnica de Cristina de Souza Agostini e Dioclézio Domingos Faustino, Editora Paulus, São Paulo, 2012.

. Syntaxe et sémantique de l'être dans le poème de Parménide, in Études sur Parménide, Tome II, Librairie J. Vrin, Paris, 1987.

. Une occasion manquée: la genèse avortée de la distinction entre l'"étant" et le "quelque chose”, in Études sur le Sophiste de Platon, Bibliopolis, Nápolis, 1991, pp. 365-385.

BARNES, Jonathan. Aristote dans la philosophie anglo-saxonne, in Revue philosophique de Louvain, Quatrième série, Tome 75, No. 76, 1977, pp. 204-218. 
BONDESON, William. Plato's Sophist: falsehood and images, in Apeiron, vol. 6, $\mathrm{n}^{\circ} 2$, 1972, pp. 1-6.

BROWN, Lesley. Definition and Division in Plato's Sophist, in Definition in Greek Philosophy (edited by David Charles), Oxford University Press, New York, 2010, pp. 151-171.

CASSIN, Barbara. O efeito sofístico: sofística, filosofia, retórica e literatura, tradução de Ana Lúcia de Oliveira e Maria Cristina Franco Ferraz, Ed. 34, São Paulo, 2005.

. Se Parmênides: o tratado anônimo De Melisso, Xenófanes e Górgias, tradução de Cláudio Oliveira, Ed. Autêntica, Belo Horizonte, 2015.

CORDERO, Néstor-Luis. La aristotelización y platonización de Parménides por Simplicio, Argos, 38, 2015, pp. 32-51.

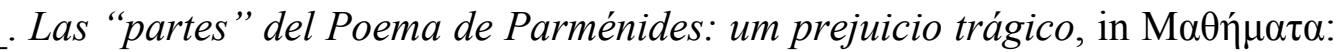
Ecos de Filosofía Antigua (ed. R. Gutiérrez), Ed. Fondo Editorial de la Pontificia Universidad Católica del Perú, Lima, 2013 (a).

. "Les deux chemins de Parménide", édition critique, traduction, études et bibliographie par Nestor-Luis Cordero, Librairie J. Vrin et Éditions OUSIA, Paris, 1997.

. The relativization of "separation" (khorismos) in the Sophist, in Plato's "Sophist" Revisited (orgs. Beatriz Bossi and Thomas M. Robinson), Walter de Gruyter, Berlim, 2013 (b), pp. 187-201.

DIELS, H.; KRANZ, W. "Die Fragmente der Vorsokratiker", Weidmann, Zürich, 1989 DIXSAUT, Monique. Platon et la question de la pensée (Études platoniciennes I), Librairie J. Vrin, Paris, 2000. 
GRANGER, Gilles-Gaston. Langages et épistémologie, Klincksieck, Paris, 1979.

HADOT, Pierre. L'être et l'étant dans le néoplatonisme, in Revue de Théologie et de Philosophie, Troisième série, Vol. 23, No. 2, 1973, pp. 101-115.

. Le voile d'Isis, Gallimard, Paris, 2004.

. Philosophie, exégèse et contresens [1968], in Études de philosophie ancienne, Les Belles Lettres, Paris, 2010, pp. 3-11.

. Porphyre et Victorinus, Études Augustiniennes, Paris, 1968.

HEINAMAN, Robert. Self-Predication in the Sophist, Phronesis, Vol. 26, No. 1, 1981, pp. 55-66.

LLOYD, A. C. Plato's description of division, in Studies in Plato's metaphysics (edited by R. E. Allen), Routledge and Kegan Paul, London, 1967, pp. 219-230.

LOPES DOS SANTOS, Luiz Henrique. A essência da proposição e a essência do mundo, in WITTGENSTEIN, L. Tractatus Logico-Philosophicus, São Paulo, Edusp, 2010.

ŁUKASIEWICZ, Jan. Remarques philosophiques sur les systèmes du calcul propositionnel multivalents, in Écrits logiques et philosophiques: introduction, traduction et notes par Sébastien Richard, Fabien Shang et Katia Vandenborre, Paris Librairie J. Vrin, 2013.

MATTÉI, Jean-François, L'Étranger et le simulacre, PUF, Paris, 1983.

MORAVCSIK, M. E. Plato's method of division, in Patterns in Plato's Thought (org. Moravcsik), D. Reidel Publishing Company, Dordrecht-Holland, 1973, pp. 158-180. 
. $\Sigma$ YМГТ $\Lambda \mathrm{OKH} \mathrm{EI} \Delta \Omega \mathrm{N}$ and the genesis of $\Lambda \mathrm{O} Г \mathrm{O} \Sigma$, Archiv für Geschichte der Philosophie 42, 1960, pp. 117-129..

O'BRIEN, Denis. Théories de la proposition dans le Sophiste de Platon, in Théories de la phrase et de la proposition de Platon à Averroès, Presses de l'École Normale Supérieure, Paris, 1999.

OWEN, G. E. L. Gilbert Ryle, Proceedings of the Aristotelian Society, New Series, Vol. 77, 1976-1977, pp. 265-270.

. Logic and Metaphysics in some Earlier Works of Aristotle [1957], in Logic, Science and Dialectic, Cornell University Press, Ithaca, 1986, pp. 180-199.

. The Platonism of Aristotle [1966], in Logic, Science and Dialectic, Cornell University Press, Ithaca, 1986, pp. 200-220.

PALUMBO, Lidia. Mimesis in the Sophist, in Plato's Sophist revisited (edited by Beatriz Bossi and Thomas Robinson), Walter de Gruyter, Berlin, 2013, pp. 269-278.

PARMÊNIDES, Sobre a natureza, Tradução de José Cavalcante de Souza, in Coleção Os Pensadores: Os pré Socráticos, Abril Cultural, São Paulo, 1973.

PELLEGRIN, Pierre. Le Sophiste ou de la division: Aristote-Platon-Aristote in Études sur le Sophiste de Platon (org. Pierre Aubenque), Bibliopolis, Napoles, 1991.

PIMENTA MARQUES. Marcelo. Platão, pensador da diferença: uma leitura do Sofista, Editora UFMG, Belo Horizonte, 2006.

PLATÃO. Fedro, traduzido por José Cavalcante de Souza, Editora 34, São Paulo, 2016. . Filebo, traduzido por Fernando Muniz, Editora Loyola, São Paulo, 2012 (a). 
. Le Politique, texte établi et traduit par A. Diès, Éditions Les Belles Lettres, Paris, 2012 (b).

.Le Sophiste, traduction, introduction et notes par Néstor-Luis Cordero, GarnierFlammarion, Paris, 1993.

Le Sophiste, texte traduit et établi par A. Diès, Éditions Les Belles Lettres, Paris, 2011. (a)

. O Sofista, tradução: Henrique Murachco, Juvino Maia Jr. e José Trindade Santos, Fundação Calouste Gulbenkian, Lisboa, 2011. (b)

Platonis Opera, Oxford University Press, New York, 1901-2003.

PRINCE, Susan. Antisthenes of Athens: texts, translations, and commentary, University of Michigan Press, 2015.

RYLE, Gilbert. Autobiographical, in Ryle, edited by Oscar P. Wood and George Pitcher, Macmillan and Co., 1970, pp. 1-15.

. Letters and Syllabes in Plato [1960], in Collected Papers Volume 1: Critical Essays, Routledge, New York, 2009, pp. 57-75.

. Plato's Parmenides [1939], in Collected Papers Volume 1: Critical Essays, Routledge, New York, 2009, pp. 1-46.

. Plato's Progress, Cambridge University Press, Londres, 1966.

SOULEZ, Antonia. La grammaire philosophique chez Platon, PUF, Paris, 1991.

SOUZA, Eliane Christiana de. Discurso e ontologia em Platão: um estudo sobre o Sofista, Ed. Unijuí, Ijuí, 2009. 
UNTERSTEINER, Mario. Sofisti: Testimonianze e Frammenti, a cura de Mario Untersteiner, introduzione di Giovanni Reale e indici di Vincenzo Cicero, Edizione Bompiani Testi a Fronte, Milano, 2009.

VASILIU, Anca. Dire et Voir: La parole visible du sophiste, Librairie J. Vrin, Paris, 2009.

WHITEHEAD, Alfred-North. Process and reality, The Free Press, New York, 1978. 